\title{
23. THE NANNOFOSSIL ASSEMBLAGES OF DEEP SEA DRILLING PROJECT LEG 66, MIDDLE AMERICA TRENCH ${ }^{1}$
}

\author{
Herbert Stradner and Franz Allram, Geologische Bundesanstalt, A-1031 Vienna, Austria
}

\section{INTRODUCTION}

Late Tertiary and Quaternary sediments were recovered in the deep sea drillings of Leg 66 at 8 sites along two transects across the Middle America Trench (Fig. 1). More than 1500 calcareous nannofossil samples were collected and their content checked in the shipboard paleo-lab and in the home laboratory at the Geological Survey of Austria in Vienna. One of the objectives was the determination of geologic age by means of nannofossil biostratigraphy; another was to collect data on the history of the trench sediments and on the amount of reworking along the active margin off southern Mexico. Coring was continuous at all sites. No Mesozoic and no early Tertiary nannofossil assemblages were encountered. Reworking was shown to have occurred only within the late Tertiary and Quaternary sediments, with no evidence of older nannofossils being involved in sediment transport.

More than 1500 smear slides were prepared from the untreated samples; those selected for special studies were ultrasonicated and centrifuged. Samples were separated into two fractions. The coarser residue was checked for discoasters and larger placoliths, and the finer fraction was utilized to study sphenoliths and smaller placoliths. The amount of debris from eroded continent and shelf is considerable in most of these near-shore drilling sites. In the average sample from the Middle America Trench, quantity and quality of nannofossil is moderate to poor. Many samples, especially those with large amount of silica, are entirely void of calcareous nannofossils. Only very few samples were found to contain favorably preserved nannofossils in sufficient numbers to make electron microscopic investigations rewarding. Figure 1 shows the locations of the eight drilling sites off Southern Mexico. In biostratigraphy section Figure 2 gives an overall view of the nannofossil assemblages of Leg 66 and their geologic age, and the tables in the site summary sections present nannofossil content. Although more than one sample from each section was prepared and studied by light microscope, only one sample per section is listed. In addition to these nannofossil tables there is a small correlation table for each site except Site 486. (Lithology and environment columns are from Moore et al., in press; paleomagnetics are from Niitsuma, this volume.)

\footnotetext{
1 Initial Reports of the Deep Sea Drilling Project, Volume 66.
}

\section{SELECTED NANNOFOSSIL SPECIES}

Calcidiscus leptoporus (Murray and Blackman, 1898) Loeblich and Tappan, 1978

Calcidiscus macintyrei (Bukry and Bramlette, 1969) Loeblich and Tappan, 1978

Calcidiscus rotula (Kamptner, 1948) Loeblich and Tappan, 1978

Catinaster calyculus Martini and Bramlette, 1963

Ceratolithus cristatus Kamptner, 1954

Coccolithus miopelagicus Bukry, 1971

Coccolithus orangensis Bukry, 1971

Coccolithus pelagicus (Wallich, 1877) Schiller, 1930

Coronocyclus nitescens (Kamptner, 1964) Bramlette and Wilcoxon, 1967

Coronocyclus sp.

Crenalithus doronicoides (Black and Barnes, 1961) Roth, 1973

Cricolithus jonesii Cohen, 1965

Cyclicargolithus abisectus (Müller, 1970) Bukry, 1973

Cyclicargolithus floridanus (Roth and Hay 1967) Bukry, 1971

Discoaster aulakos Gartner, 1967

Discoaster bollii Martini and Bramlette, 1963

Discoaster brouweri Tan Sin Hok, 1927

Discoaster calcaris Gartner, 1967

Discoaster challengeri Bramlette and Riedel, 1954

Discoaster decorus (Bukry, 1971) Bukry, 1973

Discoaster deflandrei Bramlette and Riedel, 1954

Discoaster druggii Bramlette and Wilcoxon, 1967

Discoaster exilis Martini and Bramlette, 1963

Discoaster icarus Stradner, 1973

Discoaster neohamatus Bukry and Bramlette, 1969

Discoaster pentaradiatus Tan Sin Hok, 1927

Discoaster pseudovariabilis Martini and Worsley, 1971

Discoaster quinqueramus Gartner, 1969

Discoaster stellulus Gartner, 1967

Discoaster surculus Martini and Bramlette, 1963

Discoaster variabilis Martini and Bramlette, 1963

Discolithina japonica Takayama, 1967

Discolithina multipora (Kamptner, 1948) Martini, 1965

Discolithina segmenta Bukry and Percival, 1971

Emiliania huxleyi (Lohmann, 1902) Hay and Mohler, 1967

Emiliania ovata Bukry, 1973

Gephyrocapsa aperta Kamptner, 1963

Gephyrocapsa caribbeanica Boudreaux and Hay, 1967

Gephyrocapsa oceanica Kamptner, 1943

Gephyrocapsa omega Bukry, 1973

Geophyrocapsa protohuxleyi MacIntyre, 1970

Hayaster perplexus (Bramlette and Riedel, 1954) Bukry, 1973

Helicosphaera ampliaperta Bramlette and Wilcoxon, 1967

Helicosphaera carteri (Wallich, 1877) Kamptner, 1954

Helicosphaera euphratis Haq, 1966

Helicosphaera intermedia Martini, 1965

Helicosphera sellii (Bukry and Bramlette, 1969) Jafar and Martini, 1975

Lithostromation perdurum Deflandre, 1942

Micrascidites vulgaris Deflandre and Deflandre-Rigaud, 1956

Oolithotus antillarum (Cohen, 1964) Cohen and Reinhardt 1968

Orthorhabdus serratus Bramlette and Wilcoxon, 1967

Pontosphaera syracusana Lohmann, 1902

Reticulofenestra gartneri Roth and Hay, 1967

Reticulofenestra pseudoumbilica (Gartner, 1967) Gartner, 1969 


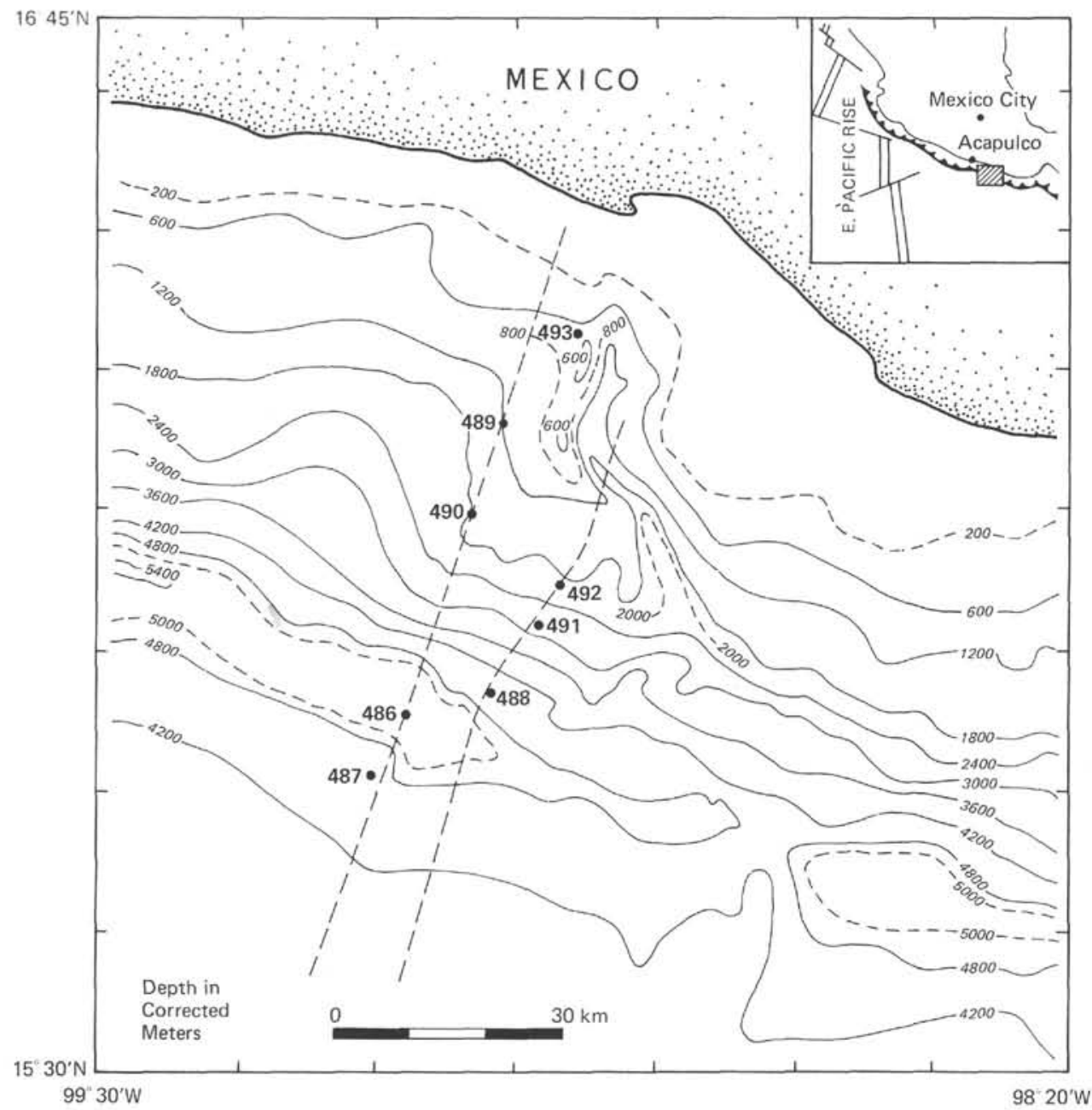

Figure 1. Location of Leg 66 sites.

Rhabdosphaera clavigera Murray and Blackman, 1898

Rhabdosphaera stylifera Lohmann, 1902

Sphenolithus abies Deflandre, 1954

Sphenolithus belemnos Bramlette and Wilcoxon, 1967

Sphenolithus delphix Bukry, 1973

Sphenolithus dissimilis Bukry and Percival, 1971

Sphenolithus heteromorphus Deflandre, 1953

Sphenolithus moriformis (Bronniman and Stradner, 1960) Bramlette and Wilcoxon, 1967

Sphenolithus neoabies Bukry and Bramlette, 1969

Syracosphaera histrica Kamptner, 1941

Thoracosphaera heimii (Lohmann, 1920) Kamptner, 1927

Thoracosphaera imperforata Kamptner, 1946

Thoracosphaera saxea Stradner, 1961

Triquetrorhabdulus auritus Stradner and Allram n.s.

Triquetrorhabdulus carinatus Martini, 1965

Triquetrorhabdulus rugosus Bramlette and Wilcoxon, 1967

Umbilicosphaera mirabilis Lohmann, 1902

\section{BIOSTRATIGRAPHY}

For the age assignment of the nannofossil assemblages, we used the standard Tertiary and Quaternary calcareous nannoplankton zonation by Martini (1971) and the low-latitude coccolith biostratigraphic zonation by Bukry $(1973,1975)$. Because of poor preservation and selective destruction by corrosion, it was impossible to detect or determine with certainty many important marker fossils. Reworking of late upper Miocene fossils into the lower Pliocene at Site 490 distorted the extent of the ranges, as revealed by comparison with the magnetostratigraphy.

Figure 2 shows the nannofossil zones it was possible to identify at Sites 486 to 493 as well as the gaps for the missing zones.

\section{The Miocene Nannofossil Zones}

NN1. Triquetrorhabdulus carinatus Zone (Fig. 3). Interval from last occurrence of Helicosphaera recta to the first occurrence of Discoaster druggii. As $H$. recta was not found in the deepest sediment at Sites 489 and 493, NN1 is considered the oldest nannoplankton zone of Leg 66. Early Miocene.

NN2. Discoaster druggii Zone. Interval from the first occurrence of $D$. druggii s. str. to the last occurrence of $T$. carinatus. With $T$. carinatus rare in our samples, the overlap of the two marker fossils was visible only in Hole 489A. At Site 493 the first occurrence of $D$. druggii and $D$. calculosus coincides with the last occurrence of $T$. carinatus. The new $T$. auritus occurs in this zone and seems to be a later evolution in the genus Triquetrorhabdulus than $T$. carinatus. Only $T$. rugosus was found to range higher-up to NN11 - at Site 490. Early Miocene. 


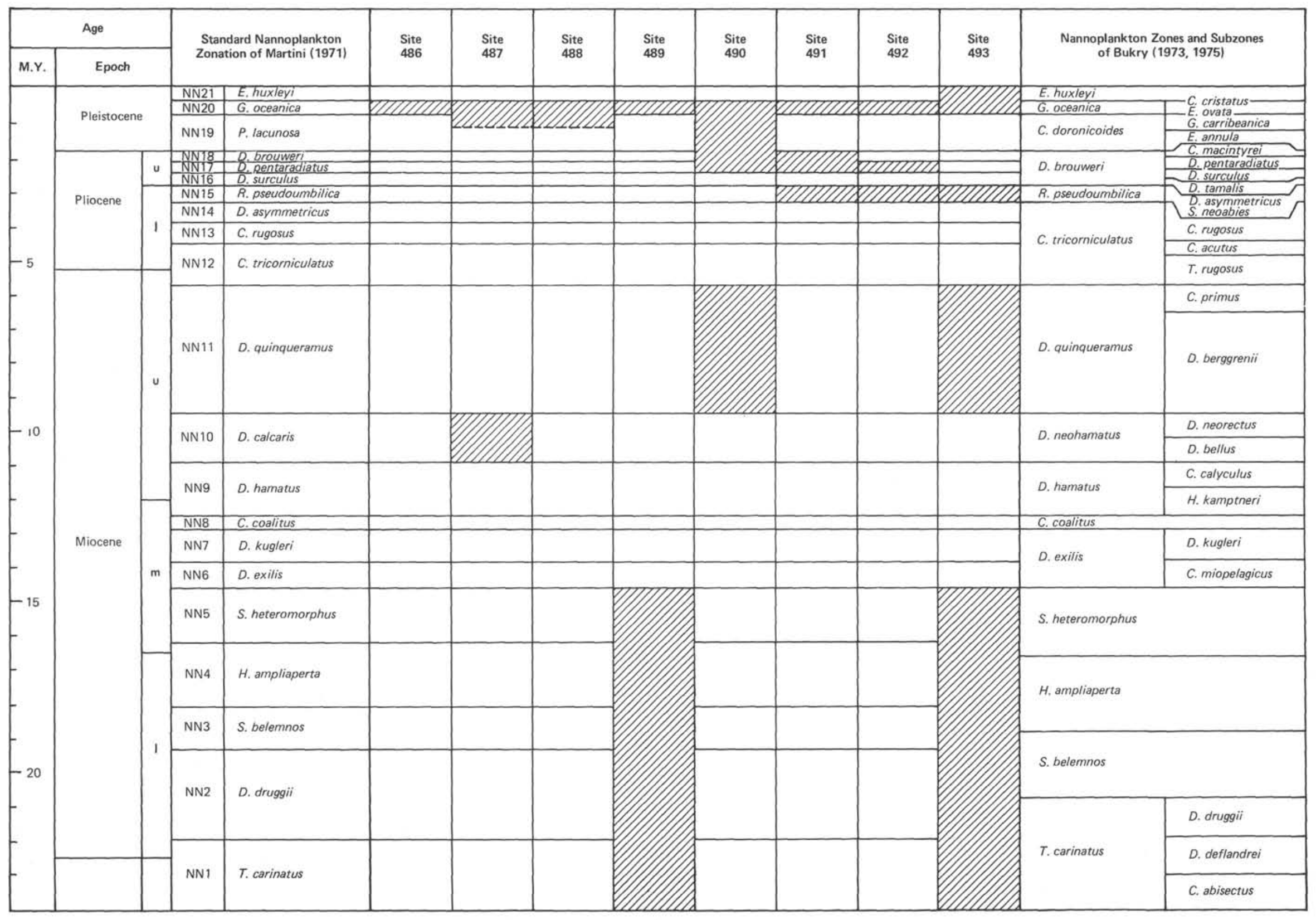

Figure 2. Nannoplankton assemblages correlated with the standard nannoplankton zonation of Martini (1971) and nannoplankton zones and subzones of Bukry (1973, 1975). 
NN3. Sphenolithus belemnos Zone. Interval from the last occurrence of $T$. carinatus to the last occurrence of $S$. belemnos. Zonal assignment to NN3 at Sites 489 and 493 is tentative owing to reduced ranges and badly corroded sphenoliths. Early Miocene.

NN4. Helicosphaera ampliaperta Zone. Interval from the last occurrence of $S$. belemnos to the last occurrence of $H$. ampliaperta. Both $H$. ampliaperta with its large oval central opening and Sphenolithus heteromorphus with its long-spined sphenoliths are typical of the NN4 zone at Sites 489 and 493 . Early to middle Miocene.

NN5. Sphenolithus heteromorphus Zone. Interval from the last occurrence of $H$. ampliaperta to the last occurrence of $S$. heteromorphus. This zone is represented only by one section of Core 2 in Hole 489A and in Cores 27 and 28 in Hole 493. The best preserved NN5 nannofossils occur in mud clasts in Section 489-1,CC. Early middle Miocene.

NN10. Discoaster calcaris Zone. Interval from the last occurrence of $D$. hamatus to the first occurrence of D. quinqueramus. This zone occurs in Core 19 of Hole 487, where $D$. calcaris, Catinaster calyculus, and $T$. rugosus were found. Late Miocene.

NN11. Discoaster quinqueramus Zone. Interval from the first to the last occurrence of $D$. quinqueramus. This zone with its typical marker fossil, a five-rayed discoaster with pronounced knobs on either flat side, occurs at Site 490 below 500 meters and at Site 493 from about 230 to 295 meters below seafloor. At Site 490 nannofossils from this zone are widely reworked into Pliocene sediments, where they dominate the zone up to Core 490-30. Late Miocene.

\section{The Pliocene Nannofossil Zones}

NN15. Reticulofenestra pseudoumbilica Zone. Interval from the last occurrence of Amaurolithus tricorniculatus s. str. to the last occurrence of $R$. pseudoumbilica. At Sites 491, 492, and 493 this zone is used for defining the co-occurrences of $R$. pseudoumbilica with often numerous Sphenolithus abies and $S$. neoabies. Because ceratolithus are virtually absent in the Pliocene of the Middle America Trench, the NN15 Zone is used for describing the lower Pliocene of these sites not excluding the possibility that it might also include one or more other lower Pliocene nannofossil zones for which there is no fossil evidence. Late early Pliocene.

NN17. Discoaster pentaradiatus Zone. Interval from the last occurrence of $D$. surculus to the last occurrence of $D$. pentaradiatus. This small nannoplankton zone, with five-rayed discoasters with curved, bifurcated rays associated with six-rayed $D$. brouweri and without any sphenoliths, is represented at Sites 490,491 , and 492 by very few core sections. Late Pliocene.

NN18. Discoaster brouweri Zone. Interval from the last occurrence of $D$. pentaradiatus to the last occurrence of $D$. brouweri. This zone with typically umbrellacurved six-rayed discoasters is to be found at Site 490 from Sections $490-16, C C$ to $490-26-6$ and at Site 491 in Core 491-4. At both sites the transition from the NN18 to the lower Quaternary NN19 is disturbed by barren samples. Late Pliocene.

\section{The Quaternary Nannofossil Zones}

NN19. Emiliania ovata (syn. Pseudoemiliania lacunosa) Zone. Interval from the last occurrence of Discoaster brouweri to the last occurrence of $E$. ovata. There is fossil evidence for this long zone, which reaches from the post-Olduvai into the lower Bruhnes at Sites 487 and 490. At Site 488 , where magnetostratigraphy indicates that this zone is to be expected, E. ovata was not found evidently because of the poor preservation of the samples. Early to middle Quaternary.

NN20. Gephyrocapsa oceanica Zone. Interval from the last occurrence of E. ovata (syn. Pseudoemiliania lacunosa) to the first occurrence of $E$. huxleyi. This zone, which lies in the upper part of the Bruhnes Normal Magnetic Epoch, is present at all sites of Leg 66. As its upper boundary is not reliably detectable without the use of an electron microscope-and then only when well-preserved samples are available-the NN20 and the subsequent NN21 zones are for practical purposes treated as one zone (Martini, 1976; Proto Decima, 1978). Late Quaternary.

NN21. Emiliania huxleyi Zone. Interval above the first occurrence of E. huxleyi. This zone, which lasts from $0.2 \mathrm{Ma}$ to present, could be identified by means of scanning and transmission electron microscopy only at Site 493. In Section 493A-2-3 both E. huxleyi and Gephyrocapsa protohuxleyi were photographed (Plate 12). Attempts to identify this zone for other sites of Leg 66 have failed. Late Quaternary.

\section{Site 486 \\ $\left(15^{\circ} 54.83^{\prime} \mathrm{N}, 9^{\circ} 08.28^{\prime} \mathrm{W}\right.$, depth $\left.5138.1 \mathrm{~m}\right)$}

Site 486 is located in the Middle America Trench 120 $\mathrm{km}$ southeast of Acapulco, Mexico. The majority of the samples taken from the five cores of Hole 486 as well as from Cores 486A-1 and 486A-3 contain a sparse and poorly preserved nannofossil assemblage of Quaternary age. The nannofossils seem to be redeposited elements of near-shore or shelf environments carried down to their present position below the CCD together with the bulk of the coarse material from upslope. Zonal assignment is NN20, the Gephyrocapsa oceanica Zone, as neither the older Emiliania ovata nor the younger $E$. huxleyi was found. The stratigraphic distribution and data on abundance and preservation of the assemblages are shown in Table 1. Only Quaternary coccoliths were found; there was no evidence of reworking of Mesozoic or Tertiary nannofossils.

\section{Site 487 \\ $\left(15^{\circ} 51.21 \mathrm{~N}, 9^{\circ} 10.52 \mathrm{~W}\right.$, depth $\left.4764 \mathrm{~m}\right)$}

Site 487 is the ocean crust reference hole for the Oaxaca-Guerrero Middle America Trench transect. This is the seawardmost site of the transect and lies $11 \mathrm{~km}$ seaward of the trench axis. Of the 19 sediment cores recovered from Hole 487, only Cores 1 to 10 and Core 19 contain calcareous nannofossils. Cores 1 to 5 are assigned to the late Quaternary Gephyrocapsa oceanica Zone NN20. These assemblages were deposited after the extinction of Emiliania ovata (syn. Pseudoumbiliania 
lacunosa). Core 6 is barren. Cores 7 to 10 with E. ovata is considered to belong to Zone NN19. The zonal marker fossil is rather rare among the dominant Gephyrocapsa placoliths.

The soupy and sandy parts of Cores 19 and 20 contain middle or late Miocene nannofossils. Discoasters and placoliths are partly etched, partly overgrown. The assemblages contain Discoaster exilis, $D$. variabilis, $D$. calcaris, $D$. bollii, $D$. stellulus, $D$. pentaradiatus, Sphenolithus abies, Triquetrorhabdulus rugosus, common Coccolithus miopelagicus, Cyclicargolithus floridanus, and Coronocyclus sp. (=?Craspedolithus ragulus). The age assignment for this nannoplankton assemblage, which may be reworked, is probably late Miocene Zone NN10. Those parts of the cores which are clayey and layered are barren. The middle to late Miocene nannofossils in Core 19 correlate well with the Ommatartus antepenultimus radiolarian zone and Paleomagnetic Epoch 9. The Globorotalia acostaensis datum places this core in the late Miocene. Globorotalia acostaensis appears at the base of the sedimentary sequence at the type section of the Tortonian stage in Italy (Cita and Blow, 1969). (See chapters by Butt, McMillen, and Niitsuma, this volume.)

The stratigraphic distribution of the nannofossils and additional data on abundance and preservation of the assemblages are shown in Tables 2 to 3 .

\section{Site 488 \\ $\left(15^{\circ} 57.10^{\prime} \mathrm{N}, 9^{\circ} 01.66^{\prime} \mathrm{W}\right.$, depth, $\left.4254 \mathrm{~m}\right)$}

Site 488 lies on the crest of the first high landward of the Middle America Trench. Cores 1 to 46 contain Quaternary sediments, which besides their high content of mud, muddy silt, sand, and organic debris have only sparse nannofossils. Gephyrocapsa oceanica was found down to Core 43 at 400 meters. No Emiliania species-either E. huxleyi, indicating NN21, or E. ovata, indicating NN19-were found. Also, scanning electron microscopy failed to prove the presence of Emiliania huxleyi in the upper cores at this site. Thus the calcareous nannofossils at Site 488 are assigned to the $G$. oceanica Zone as defined by Bukry (1973), with the namegiving fossil first occurring at $0.9 \mathrm{Ma}$. There is good correlation with magnetostratigraphy and, from Cores 1 through 25 , with planktonic foraminifers as well.

The stratigraphic distribution of the nannofossils and information on abundance and preservation of the assemblages are shown on Tables 4 and 5 .

\section{Site 489 \\ $\left(16^{\circ} 16.19^{\prime} \mathrm{N}, 9^{\circ} 01.13^{\prime} \mathrm{W}\right.$, depth, $\left.1240 \mathrm{~m}\right)$}

Site 489 lies on the upper slope of the Middle America Trench off southwestern Mexico. Two boreholes, 489 and $489 \mathrm{~A}$, the latter supplementing and continuing the first, penetrated Quaternary and lower Miocene sediments to reach basement at 300 meters.

In the Quaternary assemblages of Cores 489-1 and 489A-1 Gephyrocapsa oceanica is common; neither Emiliania ovata nor $E$. huxleyi was found. Age assignments NN20, middle to late Quaternary.
The early Miocene nannoplankton assemblages, from Zones NN1 to NN5 in Hole 489 and NN1 to NN4 in $489 \mathrm{~A}$, are not well preserved owing to high amounts of silica remains (diatoms, radiolarians, and sponge spicules). Only in reworked mudclasts in Section 489-1,CC were well-preserved discoasters found. The respective zonal markers do not occur to the full extent of the expected range but, as in the case of Sphenolithus belemnos, are interrupted by barren intervals. Triquetrorhabdulus carinatus was found from Sections 489A-12,CC to 489A-26-4 and Discoaster druggii and D. calculosus from 489A-2-1 to 489A-13-2. The new species Triquetrorhabdulus auritus was limited to the NN2 Zone in Sections 489 A-10-3 to $489 \mathrm{~A}-13-3$ and can be correlated with a similar occurrence in Hole 493, where it is also limited to NN2. Sphenolithus belemnos occurred with $T$. carinatus in Sections 489A-12,CC and 13-1 but was not found above the $T$. carinatus extinction. Thus the zone NN3 is only inferred. Zones NN4 and NN5-with Sphenolithus heteromorphus occurring with longspined specimens together with Helicosphaera ampliaperta in NN4 and without it in NN5-are in the later part of the early Miocene and the early part of the middle Miocene. NN4 and especially NN5 are represented only by a small packet of sediment layers, their full length cut short by erosion and capped by Quaternary sediments.

The stratigraphic distribution of the nannofossils and information on abundance and preservation of the assemblages are shown on Tables 6 through 8 .

\section{Site 490 \\ $\left(16^{\circ} 09.56^{\prime} \mathrm{N}, 9^{\circ} 03.34^{\prime} \mathrm{W}\right.$, depth $\left.1761 \mathrm{~m}\right)$}

Drilling at this site, which lies on the seaward edge of the transition zone between the accretionary zone and continental crust, penetrated 588.5 meters into argillaceous sediments of late Miocene to Quaternary age.

The very small placoliths in Core 490-1 are not assignable to Emiliania huxleyi, as electronmicroscopic investigations showed. Thus the NN21 Zone was not identified. The cores down to Section 490-6-4 belong to the Gephyrocapsa oceanica Zone NN20, which occurs after the extinction of $E$. ovata. Quaternary nannofossil assemblages with $E$. ovata and $G$. oceanica occurred from Sections 490-6-5 down to 490-15,CC and were assigned to Zone NN19. The Discoaster brouweri extinction datum lies within Core 490-16, between the core catcher (with Discoaster brouweri) and Section 3 (without). The late Pliocene $D$. brouweri Zone NN18 extends from Sections $490-16, C C$ to $490-26-6$ and the comparatively narrow $D$. pentaradiatus Zone NN17 from $490-26$, CC to 490-28-5. Below a barren interval from 490-28-6 down to $490-30-3$, assemblages with very few placoliths and dominant five-rayed $D$. quinqueramus and common sphenoliths were found. No ceratoliths were recorded. Zones NN16 to NN12, which should have been recognizable by $D$. surculus and Amaurolithus tricorniculatus s. ampl., are lacking. The Zone NN11 assemblages from 490-30, CC down to about Core 50 seem to be reworked, redeposited, and buried before dissolving completely. 
According to radiolarian correlations (McMillen, this volume, and magnetostratigraphy chapter by Niitsuma, this volume) only the cores below Core 50 are autochthonous late Miocene; the nannofossils of the upper Miocene Zone NN11 in the cores above probably were reworked.

The stratigraphic distribution of the nannofossils and information on abundance and preservation of the assemblages are shown on Tables 9 and 10 .

\section{Site 491}

$$
\left(16^{\circ} 01.74^{\prime} \mathrm{N}, 9^{\circ} 58.33^{\prime} \mathrm{W} \text {, depth, } 2883 \mathrm{~m}\right)
$$

Site 491 is located on the inner slope of the Middle America Trench. It lies about $2.1 \mathrm{~km}$ above and $14.3 \mathrm{~km}$ north-northeast of the adjacent trench floor on a steep slope of about 9 degrees. Drilling here penetrated 542 meters of lower Pliocene to late Quaternary argillaceous to sandy sediments. The nannofossil assemblages of the sediment column from $1, \mathrm{CC}$ to $59, \mathrm{CC}$ can be assigned to four different biostratigraphic zones:

The Gephyrocapsa oceanica Zone NN20 in Cores 491-1 and 491-2, with abundant placoliths in 491-1-2. No Emiliania ovata was found in these middle to upper Quaternary sediments.

The Discoaster brouweri Zone NN18 was found from Sections 491-4-2 to 491-4,CC, with barren samples above and below. Latest Pliocene.

The Discoaster pentaradiatus Zone NN17 with the name-giving species and $D$. brouweri but without sphenoliths was found in Sections 491-5,CC, 491-6-1, and 491-6,CC. Late Pliocene. The sparse assemblages from 491-8-2 down to 491-59,CC contain Reticulofenestra pseudoumbilica, Sphenolithus abies, S. neoabies, D. pentaradiatus, and Calcidiscus macintyrei. Owing to unfavorable deposition within a mostly siliceous sediment, only the more sturdy types of species survived the dissolution of the rest of the assemblage. No species restricted to the Miocene were found.

Thus the zonal assignment for Sections 491-8-2 down to $491-59, \mathrm{CC}$ is the $R$. pseudoumbilica Zone NN15, which may include other, older zones of the early Pliocene. Ceratoliths were not found.

Data on stratigraphic distribution and on abundance and preservation of Site 491 nannoplankton are shown in Tables 11 and 12.

\section{Site 492 \\ $\left(16^{\circ} 04.73^{\prime} \mathrm{N}, 9^{\circ} 56.72^{\prime} \mathrm{W}\right.$, depth, $1935 \mathrm{~m}$ and $1942 \mathrm{~m}$ [Hole 492B])}

Site 492 is located in the midslope region of the Middle America Trench. The site lies $3 \mathrm{~km}$ above and $20 \mathrm{~km}$ north-northeast of the adjacent trench floor on a steep slope of about 9 degrees. Three holes were drilled at this site. Hole 492 was drilled to a total depth of 279 meters and $492 \mathrm{~A}$ was hydraulic piston cored from sea bottom to 71.75 meters. Hole 492B was drilled for open-hole logging and geothermal investigations and did not recover nannofossiliferous sediments.

As at Site 491, nannofossil preservation except for the first three cores is very meager. The following three nannofossil were identified:
Gephyrocapsa oceanica Zone NN20 from Sections 492-1-1 down to $492-3-5$ and $492 \mathrm{~A}-1-1$ to $492 \mathrm{~A}-4-1$. Neither Emiliania ovata nor E. huxleyi was found, so the age assignment is middle to late Quaternary. According to magnetostratigraphy, however, NN19 is also to be expected and therefore is not excluded. Missing fossils ( $E$. ovata $)$ always are poor indicators in continental margin settings.

Discoaster pentaradiatus Zone NN17 with a namegiving nannofossil and without sphenoliths was found in Sections 492-3,CC and 492A-4-2. Upper Pliocene. Hiatuses occur above and below Zone NN17, as the NN18 and the NN16 zones are absent.

Below the layers with NN17, only sediments with relatively common sphenoliths and Reticulofenestra pseudoumbilica indicating early Pliocene (NN15 and down) were found. Cores $492-4$ to $492-6$ and $492 A-5$ to 492A-8 are considered Zone NN15, early Pliocene, on the basis of the absence of older species from the Miocene.

Typical index species of Miocene nannofossil are missing at Site 492. From Core 492-8 down, samples are practically devoid of placoliths except for a few rare sphenoliths, which may be Miocene or Pliocene. The stratigraphic distribution and data on abundance and preservation of the assemblages are shown in Tables $13-15$.

\section{Site 493 \\ $\left(16^{\circ} 22.86^{\prime} \mathrm{N}, 9^{\circ} 55.35^{\prime} \mathrm{W}\right.$, depth, $\left.644.8 \mathrm{~m}\right)$}

This drilling site is situated $33 \mathrm{~km}$ north of Site 492 and only about $15 \mathrm{~km}$ off the shoreline of Bahia Dulce. Hole 493 is the continental reference hole. It penetrated the entire sedimentary column and reached basement at 652 meters. Only two sediment cores were cut from Hole 493A. Hole 493B was drilled to bridge the gap from 12 to 126 meters missed at 493 by washing down between Cores 1 and 2 to 129.5 sub-bottom. Nannofossil assemblages of Quaternary, Pliocene, and late and early Miocene were recorded in this most rewarding of all Leg 66 Middle America Trench sites. Biostratigraphic correlation with foraminifers and radiolarians as well as with magnetostratigraphy is in general agreement.

Only at this site could the latest Quaternary nannofossil Emiliania huxleyi Zone NN21 be identified by means of electron microscopy. In Sample 493A-2-3, 2-3 $\mathrm{cm}, E$. huxleyi was found in rare numbers, together with Gephyrocapsa protohuxleyi and G. oceanica. Latest Quaternary deposited within the last 200,000 years.

The Gephyrocapsa oceanica Zone NN20 extends from Sections 493-1-1 down to 1,CC and from 493B-1-1 down to 493B-5-3. Middle to late Quaternary. No early Quaternary was found at this site. The late Pliocene of Hole 493B, the age of which was established with planktonic foraminifers (Butt, this volume), contains many reworked nannofossils, especially sphenoliths, of early Pliocene and possibly Miocene origin. From Sections 493B-5, CC down to 493B-12-1 Discoaster brouweri, $D$. pentaradiatus, and $D$. surculus were found, possibly 
from a late Pliocene biotope. Below an interval of 20 meters of barren sediments the Reticulofenestra pseudoumbilica Zone NN15 extends from Sections 493-5-4 down to 493-11-3: early Pliocene with Sphenolithus abies, $S$. neoabies, and $R$. pseudoumbilica.

The $D$. quinqueramus Zone NN11 of late Miocene age was found from Sample 493-13-1, 23-24 cm down to $493-27-3,100-101 \mathrm{~cm}$. The boundary between NN11 and the early Miocene NN5 with a hiatus of five nannoplankton zones was drawn between Samples 493$27-4,10-11 \mathrm{~cm}$ and $493-27-3,100-101 \mathrm{~cm}$. As at Site 489 the early Miocene of Site 493 contains a sequence of NN1 to NN5 nannofossils.

The $S$. heteromorphus Zone NN5 extends from Sample 493-27-4 down to 493-28, CC, the underlying Helicosphaera ampliamperta Zone NN4 from 493-29-3 down to $493-48, C C$. With barren intervals, the $S$. belemnos Zone NN3 is restricted to the interval from Sample $493-49, \mathrm{CC}$ to $493-51, \mathrm{CC}$. The NN1/NN2 boundary with the first occurrence of $D$. druggii and $D$. calculosus seems to lie between 493-53-1, 47-48 cm and 493-53,CC or slightly below, as indicated by the occurrence of $\mathrm{Tr} i$ quetrorhabdulus auritus in 493-53,CC. In Core 493-54 and in the sands just above basement (Sample 493-60-1, $60-61 \mathrm{~cm}$ ) $T$. carinatus is present (without $D$. druggii), which indicates the NN1 Zone. The stratigraphic distribution of the nannofossils and additional data on abundance and preservation of the assemblages are shown in Tables 16-19.

\section{DESCRIPTION OF A NEW NANNOFOSSIL SPECIES}

\section{Genus TRIQUETRORHABDULUS Martini, 1965}

Triquetrorhabdulus auritus nov. spec. Stradner and Allram (Plate 7, Figures 1-8 and text Figure 3, A-C)

Derivation of name, auritus (Latin): with ears.

Diagnosis. Calcareous bodies consisting of three elongate triangular flat blades that are united with their hypotenuse at angles of $120^{\circ}$, thus forming wedge-shaped bodies of deltoid outline in side view. At their greatest width these bodies are extended, in some specimens, into "ears" (Plate 7, Fig. 4).

Remarks. Triquetrorhabdulus auritus $\mathrm{n}$. $\mathrm{sp}$. is distinguished from $T$. carinatus by its shorter, more deltoid outline; from $T$. milowii by its projecting ridges or spineous extensions at the wide area of the blades (see Fig. $3 \mathrm{~A}-\mathrm{C}$ ). For $T$. milowii no such angular ridges or extensions have been described. Although the lateral view of $T$. milowii shows a more or less rounded outline, $T$. auritus has a more wedgeshaped outline with straight edges.

Holotype. Specimen shown in Plate 7, Figures 1 and 2.

Isotypes. Specimens shown in Plate 7, Figures 3, 4, and 6.

Dimensions (Holotype). Length: $14 \mu \mathrm{m}$. Width: $6 \mu \mathrm{m}$.

Stratum typicum. Lower Miocene, Discoaster druggii nannoplankton Zone NN2.

Type locality. DSDP Sample 489A-12,CC, Middle America Trench off Southern Mexico.

Deposition of the type specimens. Geologische Bundesanstalt Wien, Elmi-Labor.

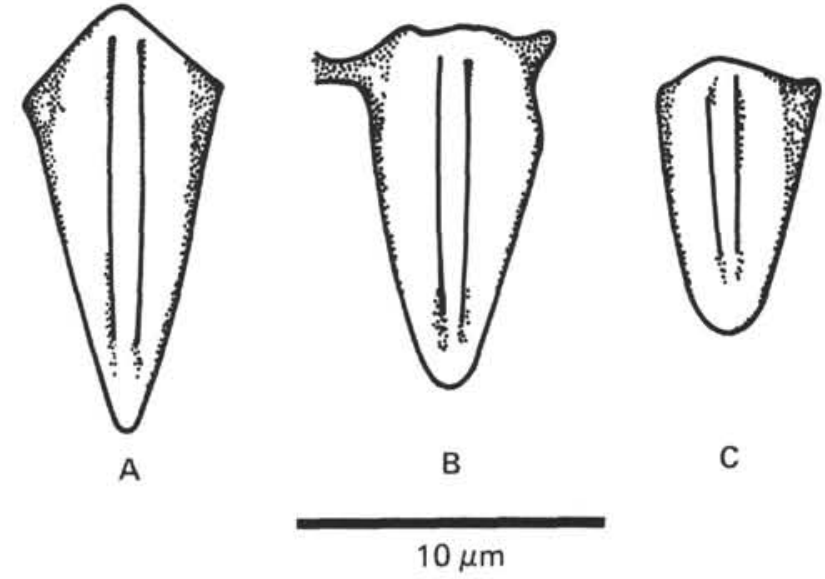

Figure 3. Triquetrorhabdulus auritus nov. spec. Side views of holotype specimen (A) and two isotype specimens (B and C). Scale bar; $10 \mu \mathrm{m}$. Sample 489A-12,CC.

\section{ACKNOWLEDGMENTS}

For their scientific advice and useful comments on the manuscript the authors thank the co-chiefs of DSDP Leg 66, Dr. Casey Moore, University of California, Santa Cruz, and Dr. Joel S. Watkins, Gulf Science \& Technology Co., Pittsburgh, Pa. For critical review of the text we thank Dr. David Bukry, United States Geological Survey, La Jolla, California, Dr. Pavel Cepek, Bundesanstalt für Geowissenschaften und Rohstoffe, Hannover, Germany, and the staff scientist, Dr. Thomas Shipley of Scripps Institution of Oceanography. Permission to use the electronmicroscope laboratory facilities of the Geological Survey of Austria was given by the Director HR. Prof. Dr. Felix Ronner and is gratefully acknowledged herewith.

\section{REFERENCES}

Bukry, D., 1973. Low-latitude coccolith biostratigraphic zonation. In Edgar, N. T., Saunders, J. B., et al., Init. Repts. DSDP, 15: Washington (U.S. Govt. Printing Office), 685-703. 1975. Coccolith and silicoflagellate stratigraphy, Northwestern Pacific Ocean, Deep Sea Drilling Project Leg 32. In Larson, R. L., Moberly, R., et al., Init. Repts. DSDP, 32: Washington (U.S. Govt. Printing Office), 677-701.

Cita, M. B., and Blow, W. H., 1969. The biostratigraphy of the Langhian, Serravallian and Tortonian stages in the type-sections in Italy. Riv. Ital. Pal. Strat., 75(3):549-603.

Martini, E., 1971. Standard Tertiary and Quaternary calcareous nannoplankton zonation. In Farinacci, A. (Ed.) Proceeding of the Second Planktonic Conference, Roma, 1970 (Vol. 2): Rome (Edizioni Tecnoscienza), 739-785.

1976. Cretaceous to Recent Calcareous Nannoplankton from the Central Pacific Ocean (DSDP Leg 33). In Schlanger, S. O., Jackson, E. D., et al., Init. Repts. DSDP, 33: Washington (U.S. Govt. Printing Office), 383-423.

Moore, J. C., and Watkins, J. S., McMillen, K., et al., in press. Facies belts of the Middle America Trench and Forearc Region, Southern Mexico: Results from Leg 66 DSDP. Conference paper for the Trench and Forearc Sedimentation and Tectonics Conference in London, June 1980.

Proto Decima, F., Medizza, F., and Todesco, L., 1978. Southeastern Atlantic Leg 40 calcareous nannofossils. In Bolli, H. M., Ryan, W. B. F., et al., Init. Repts. DSDP, 40: Washington (U.S. Govt. Printing Office), 571-634. 
Table 1. Biostratigraphic range chart, Holes 486 and 486A.

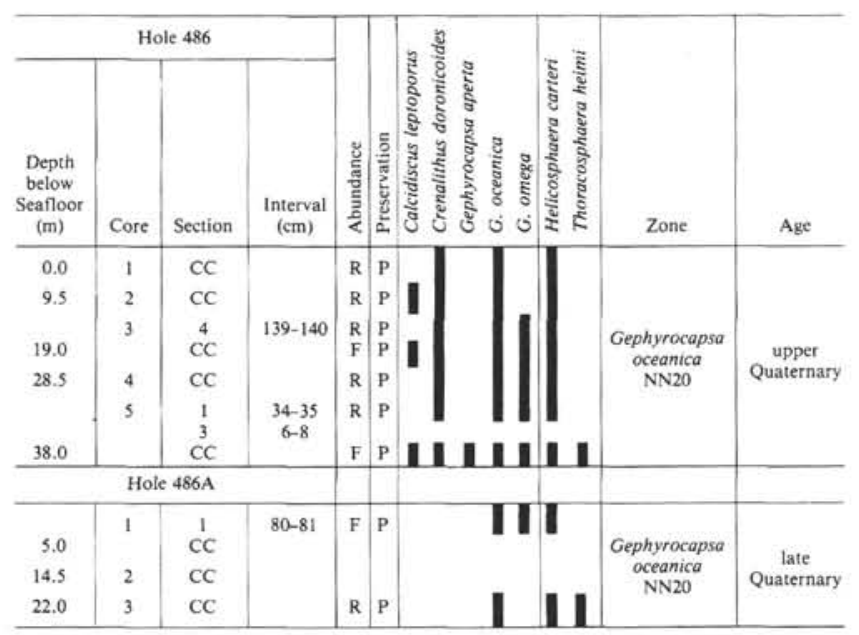

Table 2. Correlation of lithostratigraphy, biostratigraphy, and magnetostratigraphy, Hole 487.
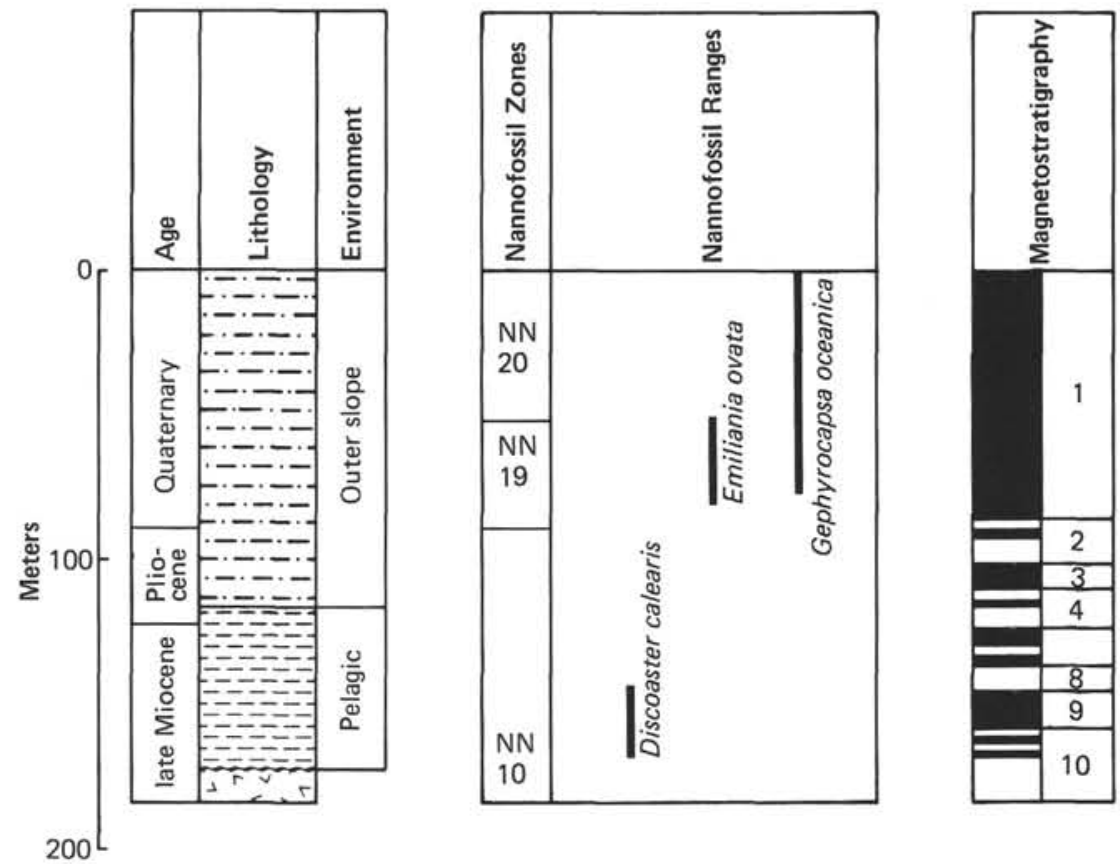
Table 3. Biostratigraphic range chart, Hole 487.

\begin{tabular}{|c|c|c|c|c|c|c|c|c|c|c|c|c|}
\hline $\begin{array}{l}\text { Depth } \\
\text { below } \\
\text { Seafloor } \\
\text { (m) }\end{array}$ & Core & Section & $\begin{array}{c}\text { Interval } \\
(\mathrm{cm})\end{array}$ & 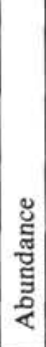 & 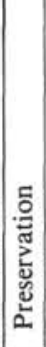 & 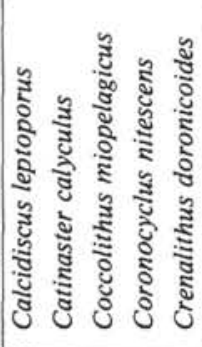 & 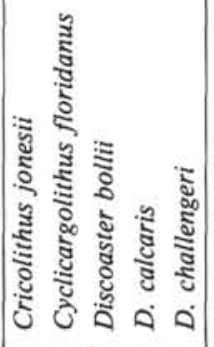 & 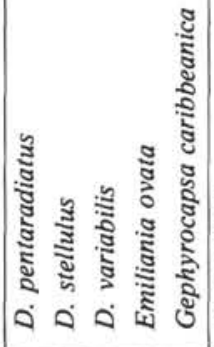 & 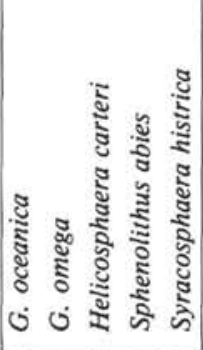 & 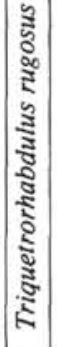 & Zone & Age \\
\hline 1.0 & 1 & $\begin{array}{c}1 \\
\text { CC }\end{array}$ & $146-148$ & $\begin{array}{l}\mathrm{R} \\
\mathrm{R} \\
\end{array}$ & $\begin{array}{l}\mathrm{P} \\
\mathrm{P}\end{array}$ & & & & & & \multirow{7}{*}{$\begin{array}{l}\text { Gephyrocapsa } \\
\text { oceanica } \\
\mathrm{NN} 20\end{array}$} & \multirow{10}{*}{$\begin{array}{l}\text { middle } \\
\text { to late } \\
\text { Quaternary }\end{array}$} \\
\hline 10.5 & 2 & $\begin{array}{c}1 \\
\mathrm{CC}\end{array}$ & $8-9$ & \begin{tabular}{|l|}
$\mathrm{R}$ \\
$\mathrm{F}$ \\
\end{tabular} & $\begin{array}{l}\mathrm{P} \\
\mathrm{P} \\
\end{array}$ & & & & & & & \\
\hline 20.0 & 3 & $\begin{array}{c}1 \\
\mathrm{CC} \\
\end{array}$ & $31-32$ & $\mathrm{R}$ & $\mathrm{P}$ & & & & & & & \\
\hline 29.5 & 4 & $\mathrm{CC}$ & & $\mathbf{R}$ & $\mathrm{P}$ & & & & & & & \\
\hline 39.0 & 5 & $\begin{array}{c}1 \\
2 \\
3 \\
\text { CC }\end{array}$ & $\begin{array}{l}60-61 \\
75-76 \\
75-76\end{array}$ & $\mathrm{R}$ & $P$ & & & & & & & \\
\hline 48.5 & 6 & $\mathrm{CC}$ & & & & & & & & & & \\
\hline 58.0 & 7 & 3 & $20-21$ & $\mathrm{C}$ & M & & & & & & & \\
\hline 67.5 & 8 & $\begin{array}{c}\mathrm{CC} \\
5 \\
\mathrm{CC} \\
\end{array}$ & $67-68$ & $\begin{array}{l}\mathrm{F} \\
\mathrm{F} \\
\end{array}$ & $\begin{array}{l}\mathrm{M} \\
\mathrm{M}\end{array}$ & & & & & & \multirow{3}{*}{$\begin{array}{c}\text { Emiliania } \\
\text { ovata } \\
\text { NN19 }\end{array}$} & \\
\hline 77.0 & 9 & $\begin{array}{c}4 \\
\mathrm{CC}\end{array}$ & $60-62$ & $\begin{array}{l}\mathrm{F} \\
\mathrm{R} \\
\end{array}$ & $\begin{array}{l}\mathrm{P} \\
\mathrm{P} \\
\end{array}$ & & & & & & & \\
\hline 86.5 & 10 & $\begin{array}{c}2 \\
3 \\
\mathrm{CC} \\
\end{array}$ & $\begin{array}{l}62-64 \\
70-72\end{array}$ & $\begin{array}{l}\mathrm{F} \\
\mathrm{R} \\
\end{array}$ & $\begin{array}{c}\mathrm{M} \\
\mathrm{P} \\
\end{array}$ & & & & & & & \\
\hline 96.0 & 11 & $\begin{array}{c}2 \\
\mathrm{CC}\end{array}$ & $77-78$ & & & & & & & & & \\
\hline 105.5 & 12 & $\begin{array}{c}2 \\
3 \\
\mathrm{CC} \\
\end{array}$ & $\begin{array}{c}7-8 \\
58-59\end{array}$ & & & & & & & & & \\
\hline 115.0 & 13 & $\begin{array}{c}3 \\
\mathrm{CC} \\
\end{array}$ & $10-11$ & & & & & & & & & \\
\hline 124.5 & 14 & $\begin{array}{c}2 \\
\mathrm{CC}\end{array}$ & $60-61$ & & & & & & & & & \\
\hline 134.0 & 15 & $\begin{array}{c}3 \\
\mathrm{CC} \\
\end{array}$ & $30-31$ & & & & & & & & & \\
\hline 143.5 & 16 & $\begin{array}{c}1 \\
\mathrm{CC}\end{array}$ & $59-60$ & & & & & & & & & \\
\hline 153.0 & 17 & $\begin{array}{c}1 \\
\mathrm{CC}\end{array}$ & $75-76$ & & & & & & & & & \\
\hline 162.5 & 18 & $\begin{array}{c}1 \\
\text { CC }\end{array}$ & $45-46$ & & & & & & & & & \\
\hline 172.0 & 19 & $\begin{array}{c}1 \\
2 \\
3 \\
4 \\
5 \\
\text { CC }\end{array}$ & $\begin{array}{c}100-102 \\
2-3 \\
50-52 \\
30-32 \\
30-32\end{array}$ & $\begin{array}{l}\mathrm{C} \\
\mathrm{C} \\
\mathrm{C} \\
\mathrm{C}\end{array}$ & \begin{tabular}{|l|}
$\mathrm{P}$ \\
$\mathrm{P}$ \\
$\mathrm{P}$ \\
$\mathrm{P}$
\end{tabular} & 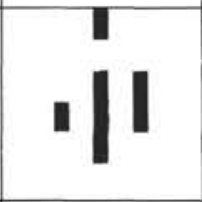 & 1 & & 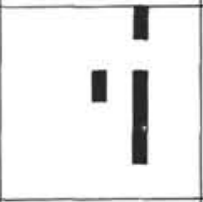 & 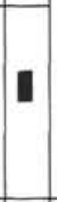 & $\begin{array}{c}\text { Discoaster } \\
\text { calcaris } \\
\text { NN10 }\end{array}$ & $\begin{array}{c}\text { late } \\
\text { Miocene }\end{array}$ \\
\hline 181.5 & 20 & 1 & $140-141$ & & & & & & & & Basem & ent \\
\hline 190.5 & 21 & $\mathrm{CC}$ & & & & & & & & & & \\
\hline
\end{tabular}


Table 4. Correlation of lithostratigraphy, biostratigraphy, and magnetostratigraphy, Hole 488.
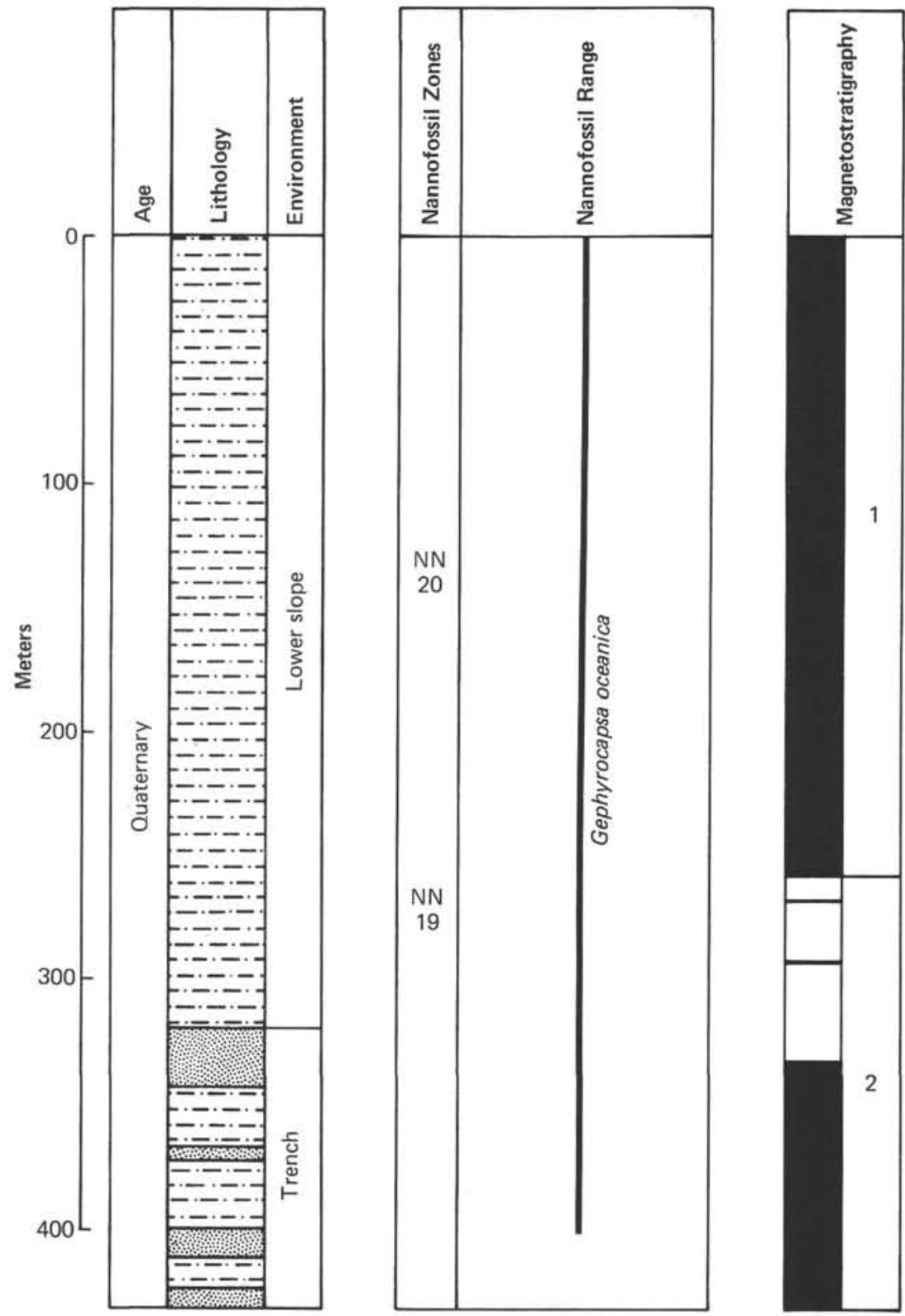
Table 5. Biostratigraphic range chart, Hole 488.

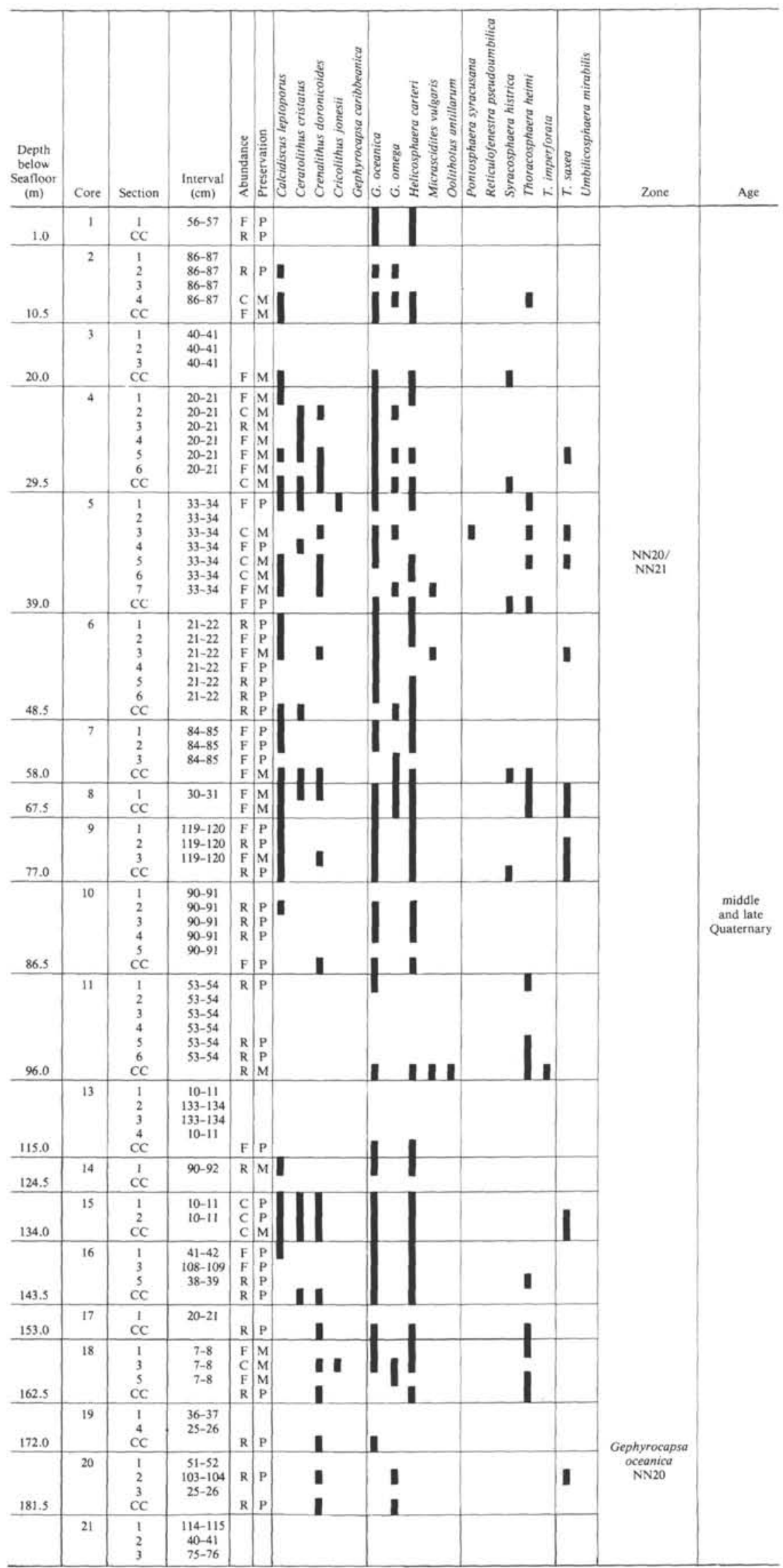


Table 5. (Continued).

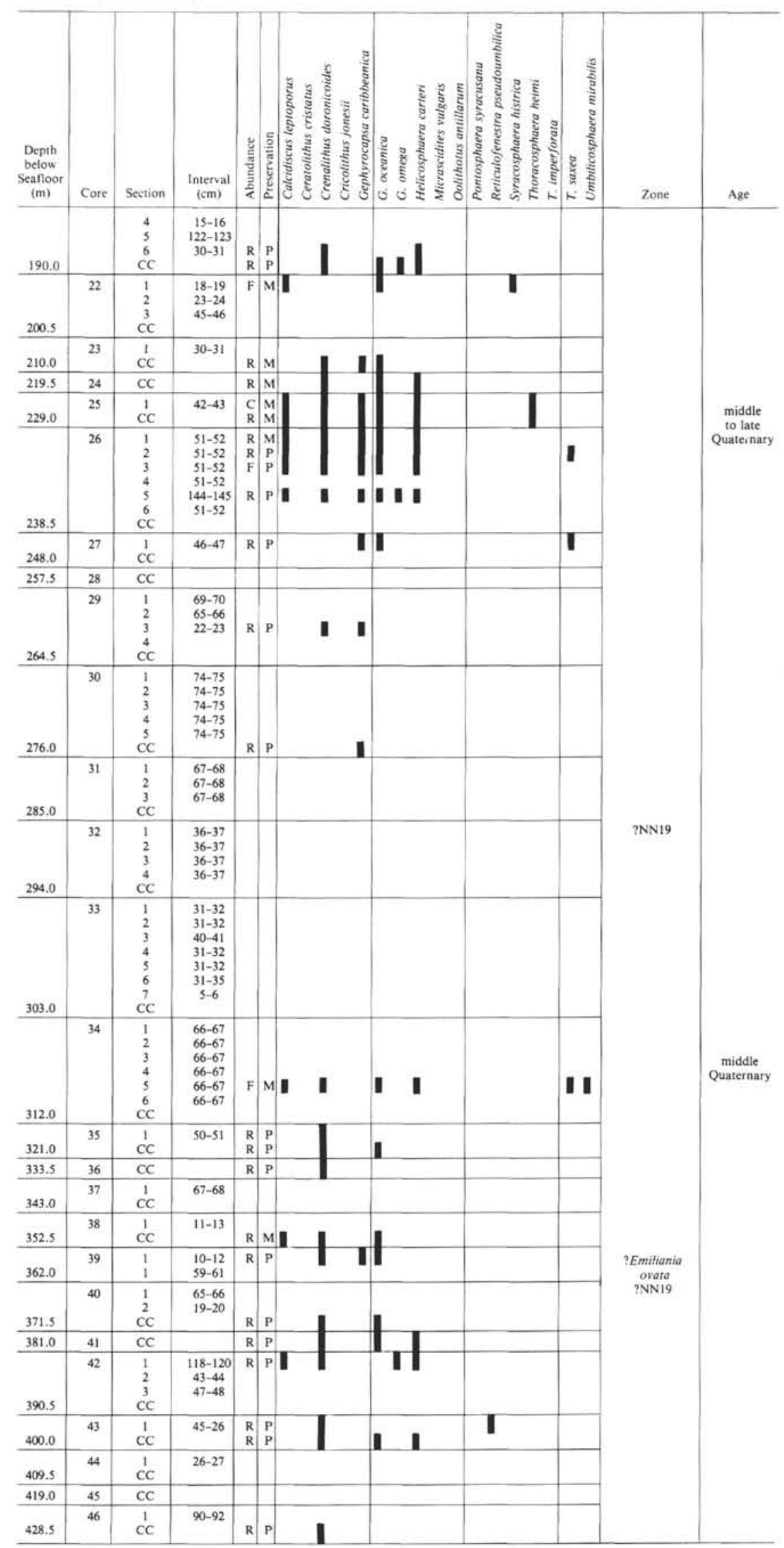


Table 6. Correlation of lithostratigraphy, biostratigraphy, and magnetostratigraphy, Holes 489 and $489 \mathrm{~A}$.
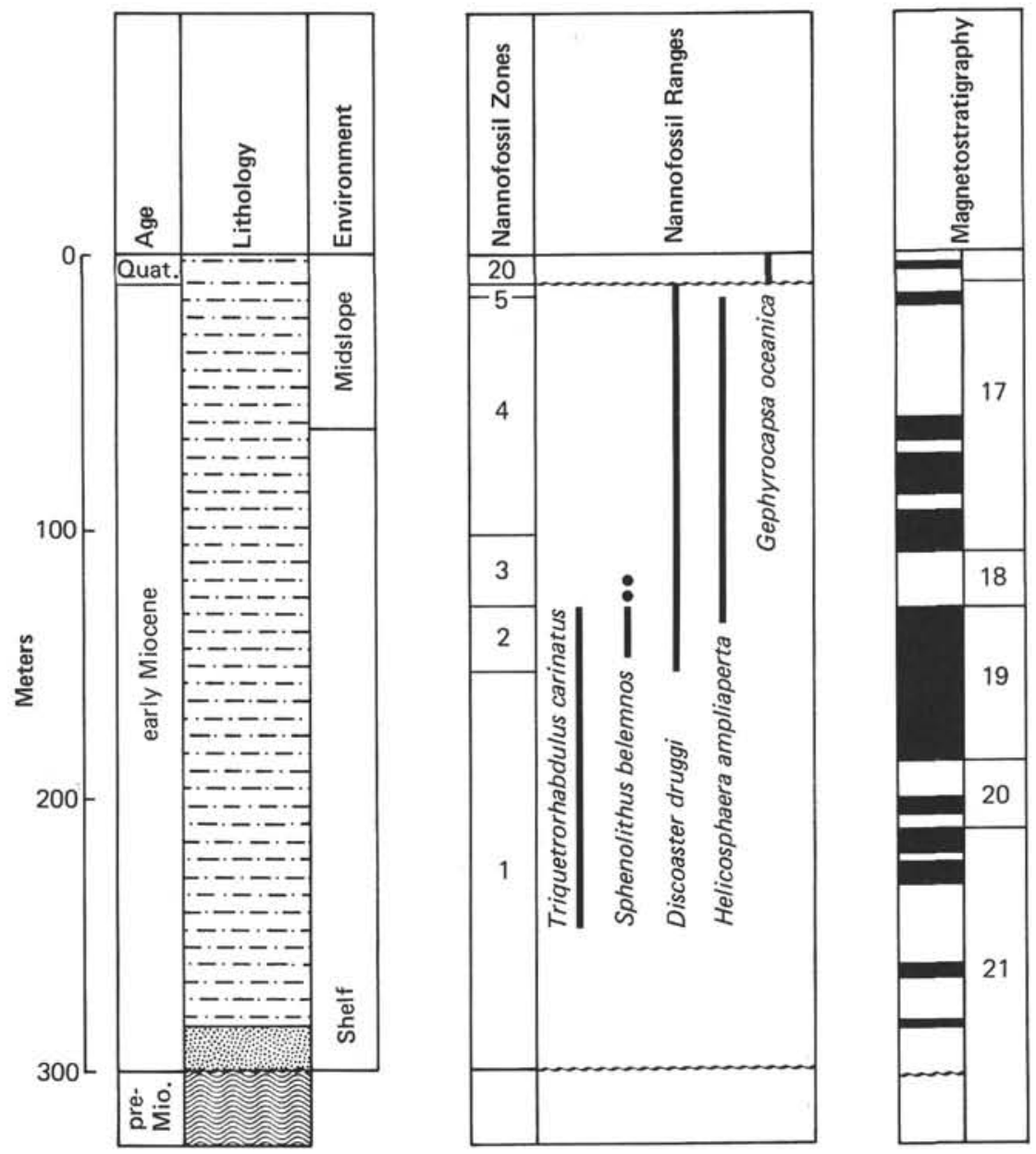

Table 7. Biostratigraphic range chart, Hole 489.

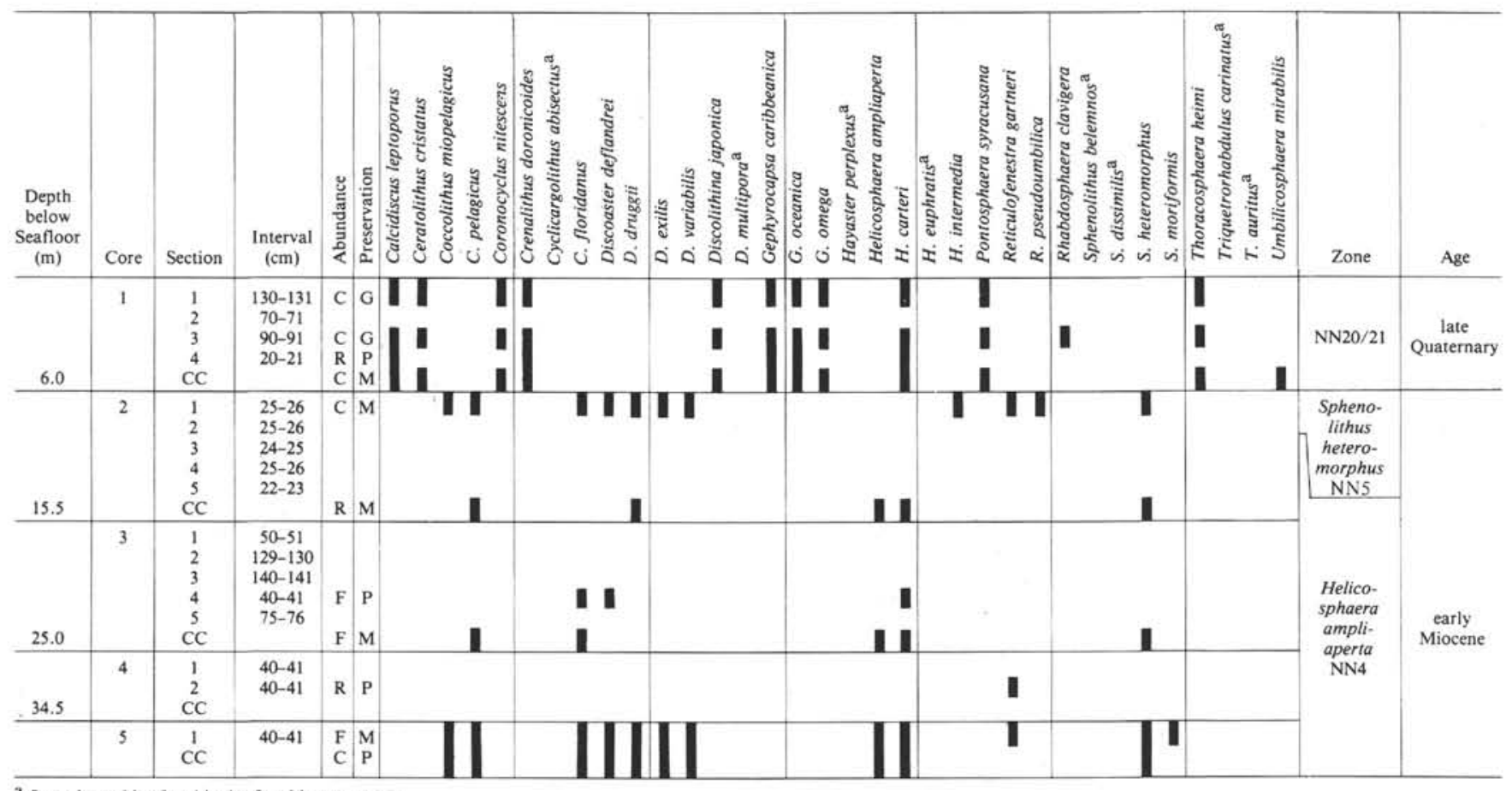

a See other tables for this site for this occurrence. 
Table 8. Biostratigraphic range chart, Hole 489A.

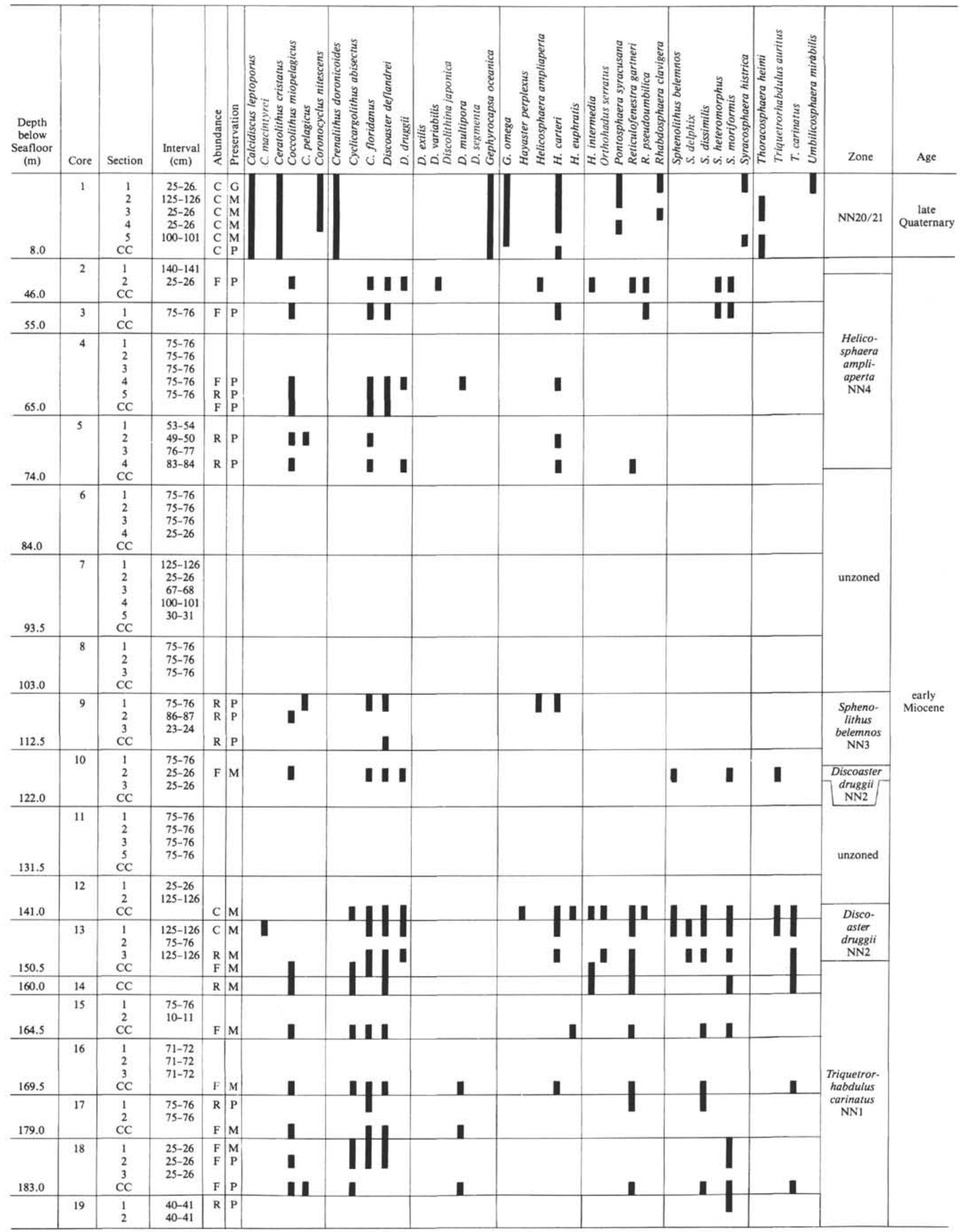


Table 8. (Continued).

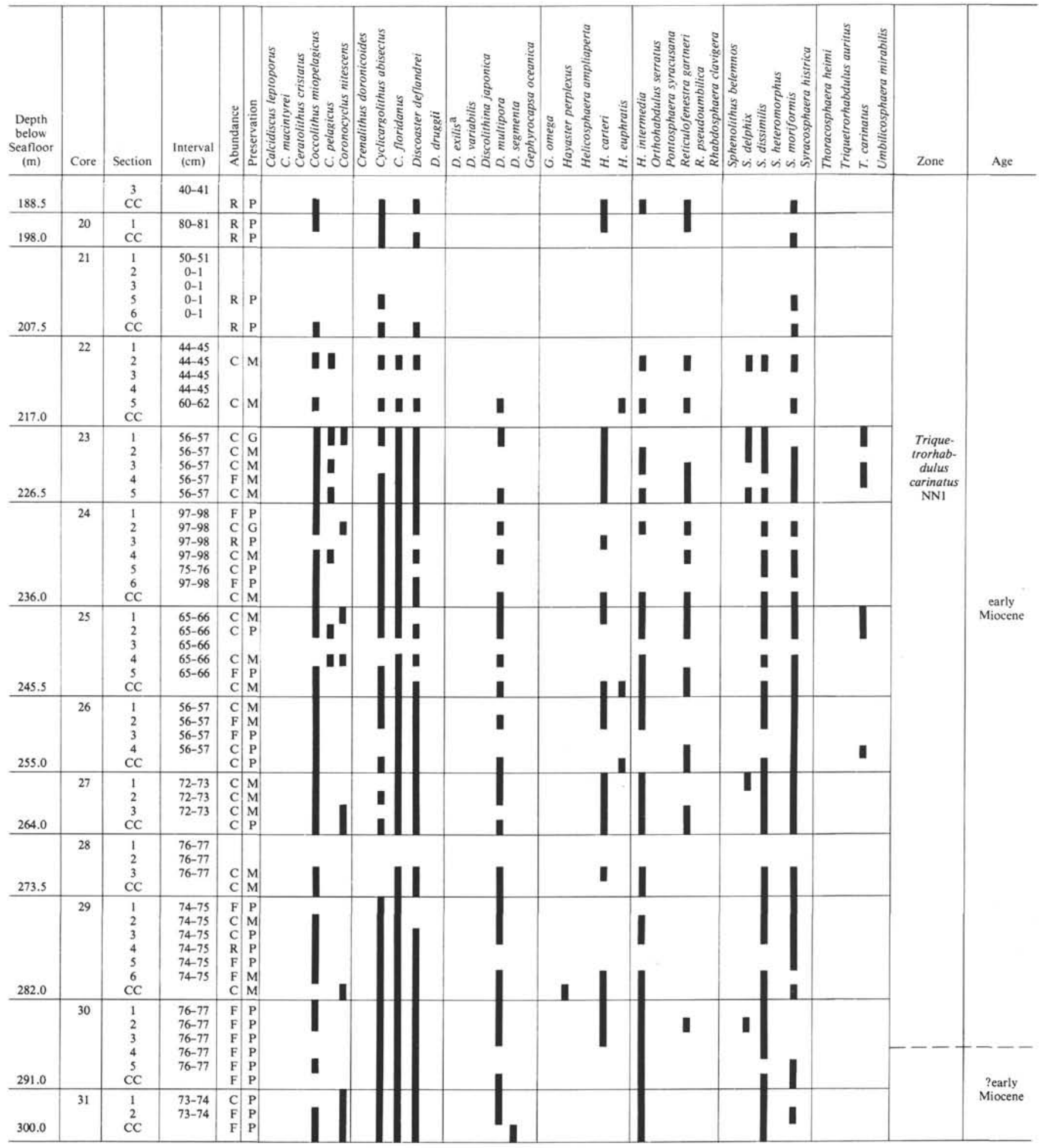


Table 9. Correlation of lithostratigraphy, biostratigraphy, and magnetostratigraphy, Hole 490.
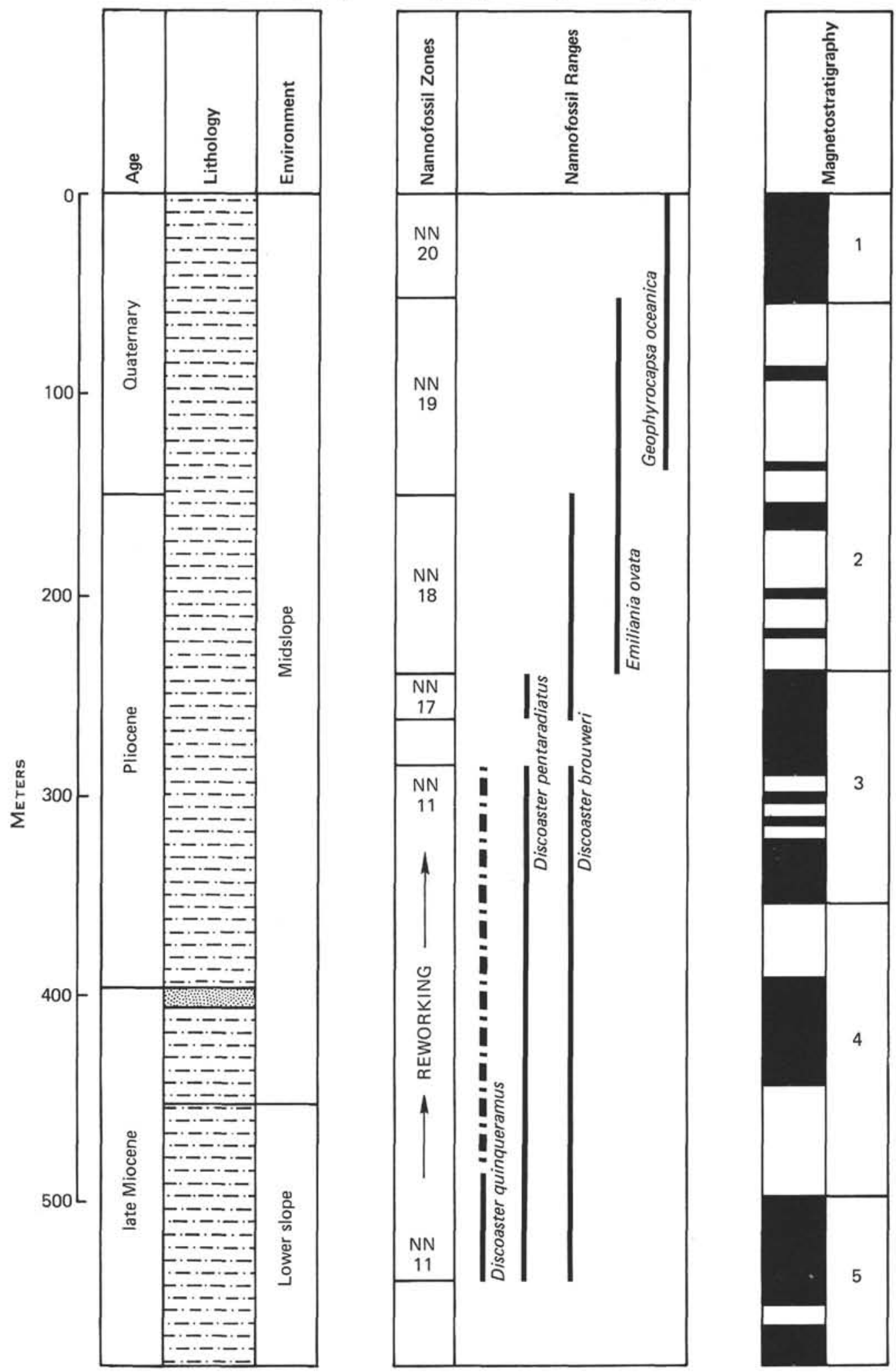
Table 10. Biostratigraphic range chart, Hole 490 .

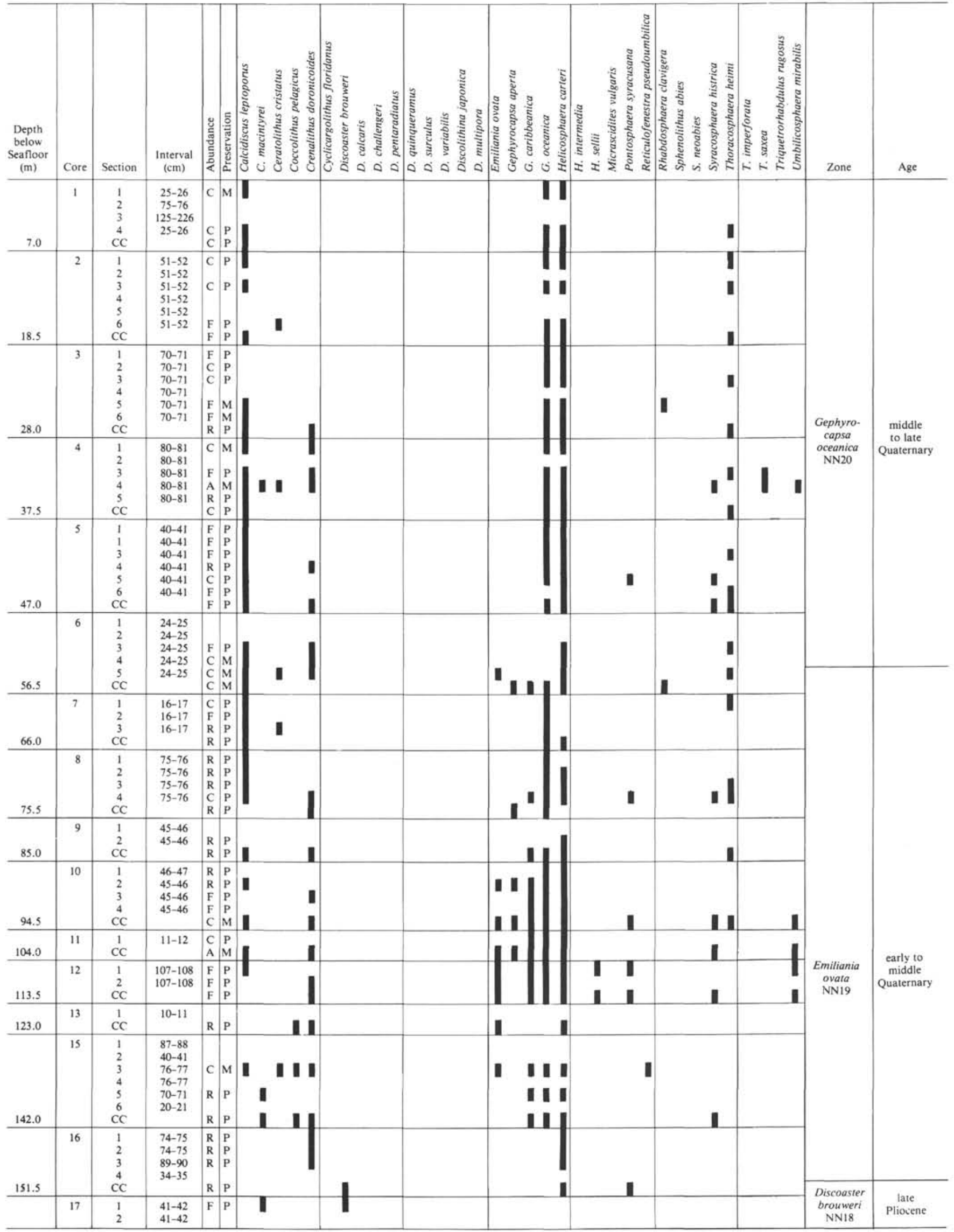


Table 10. (Continued).

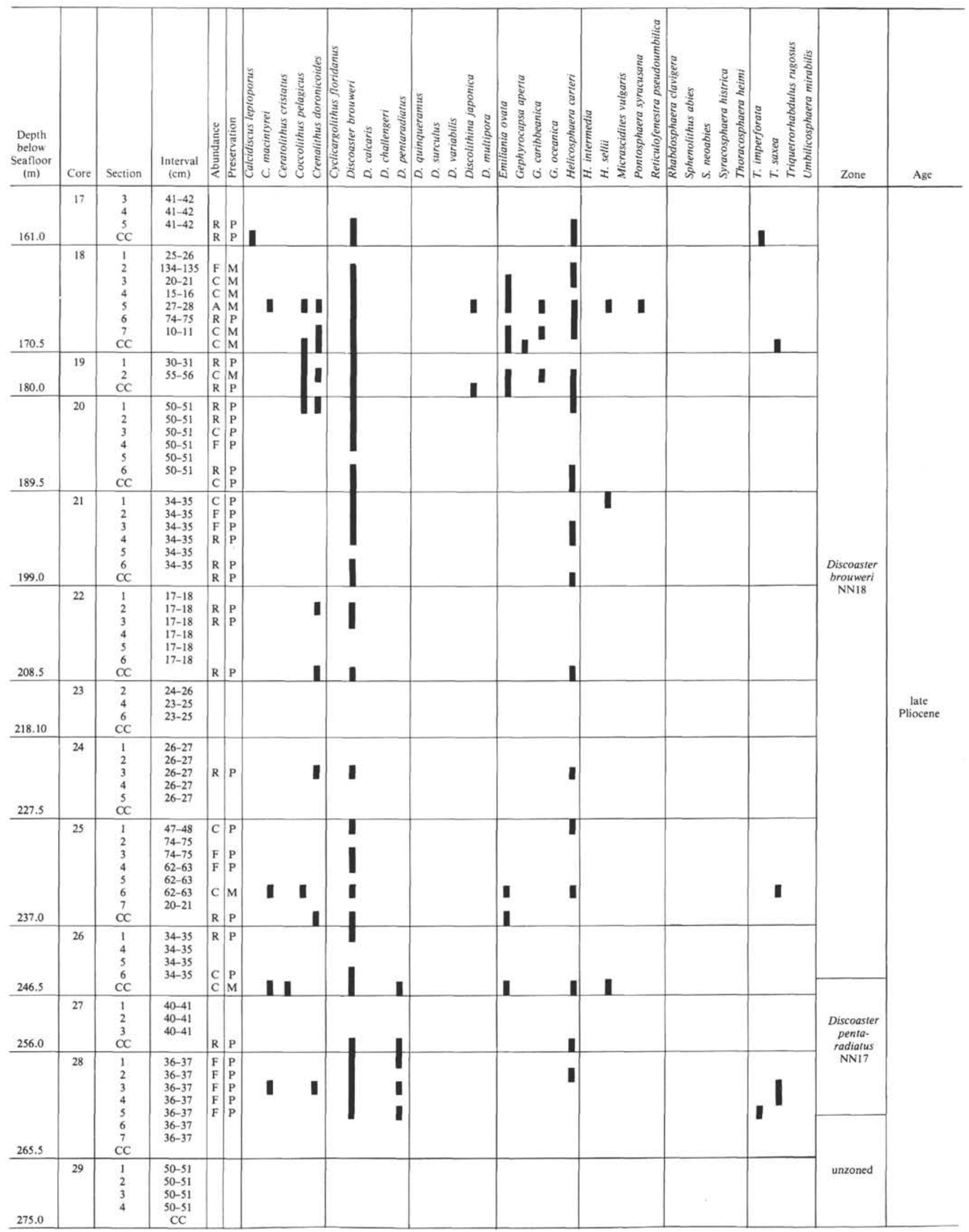


Table 10. (Continued).






\section{H. STRADNER, F. ALLRAM}

Table 10. (Continued).

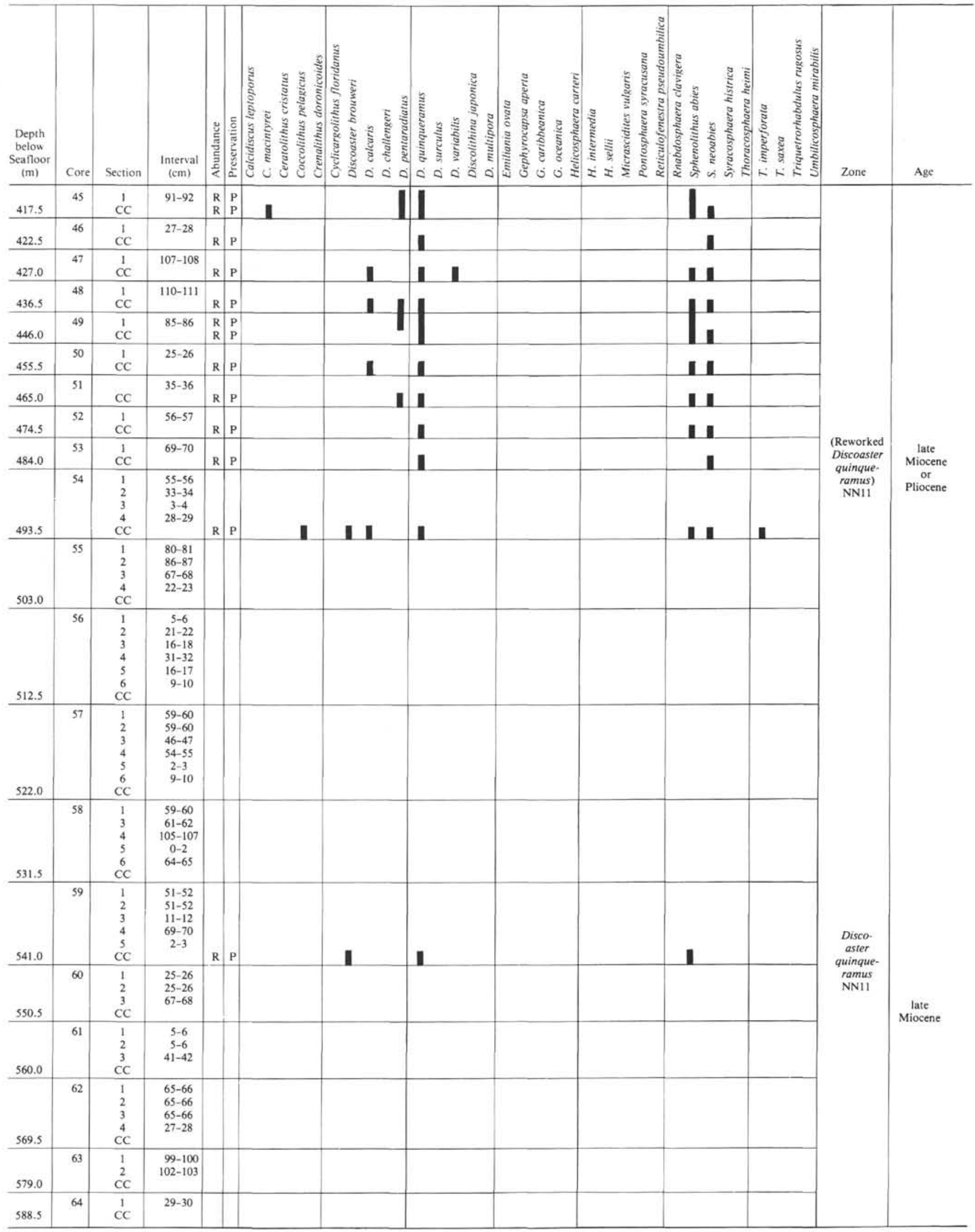


Table 11. Correlation of lithostratigraphy, biostratigraphy, and magnetostratigraphy, Hole 491 .
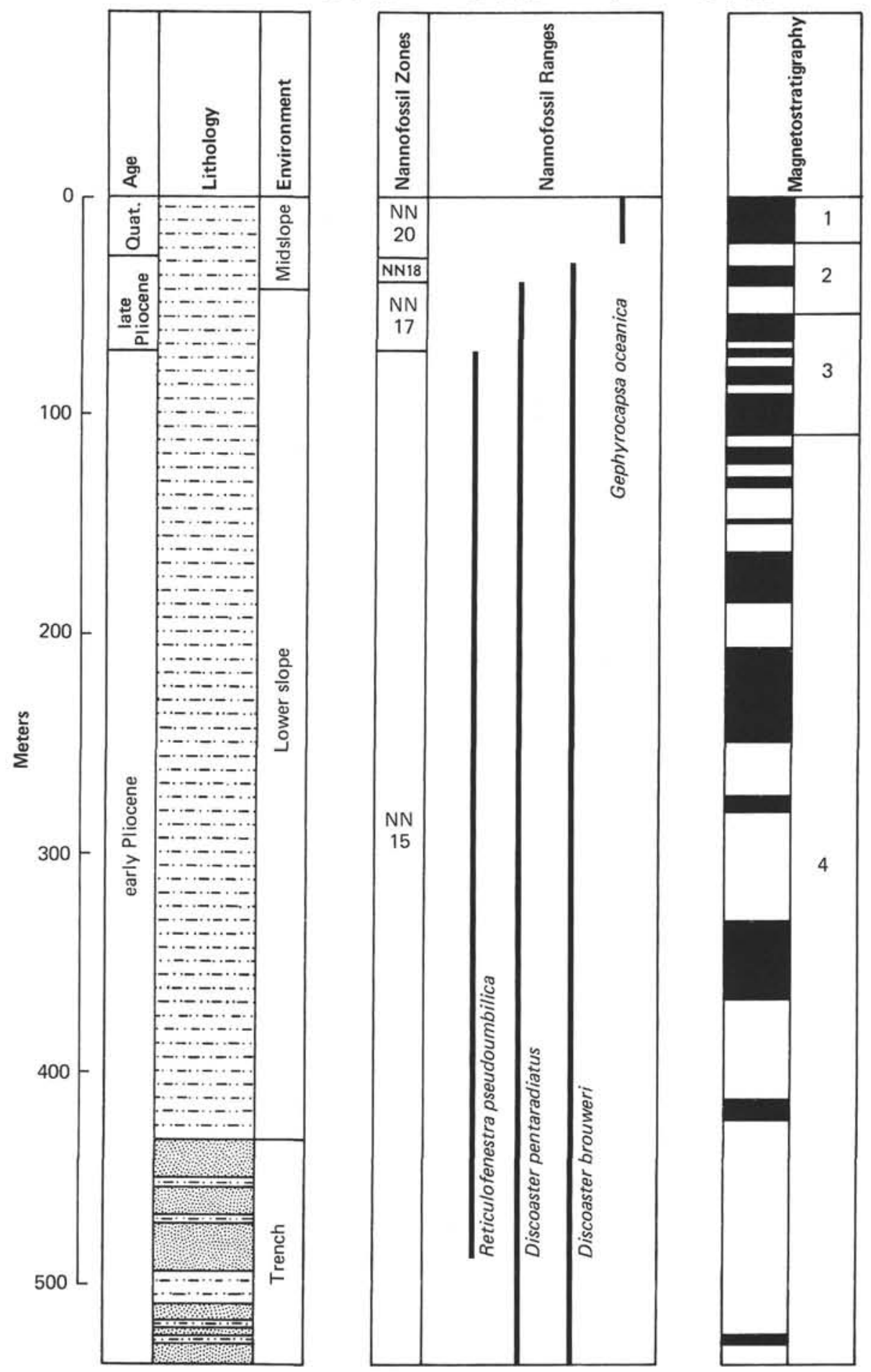
Table 12. Biostratigraphic range chart, Hole 491.

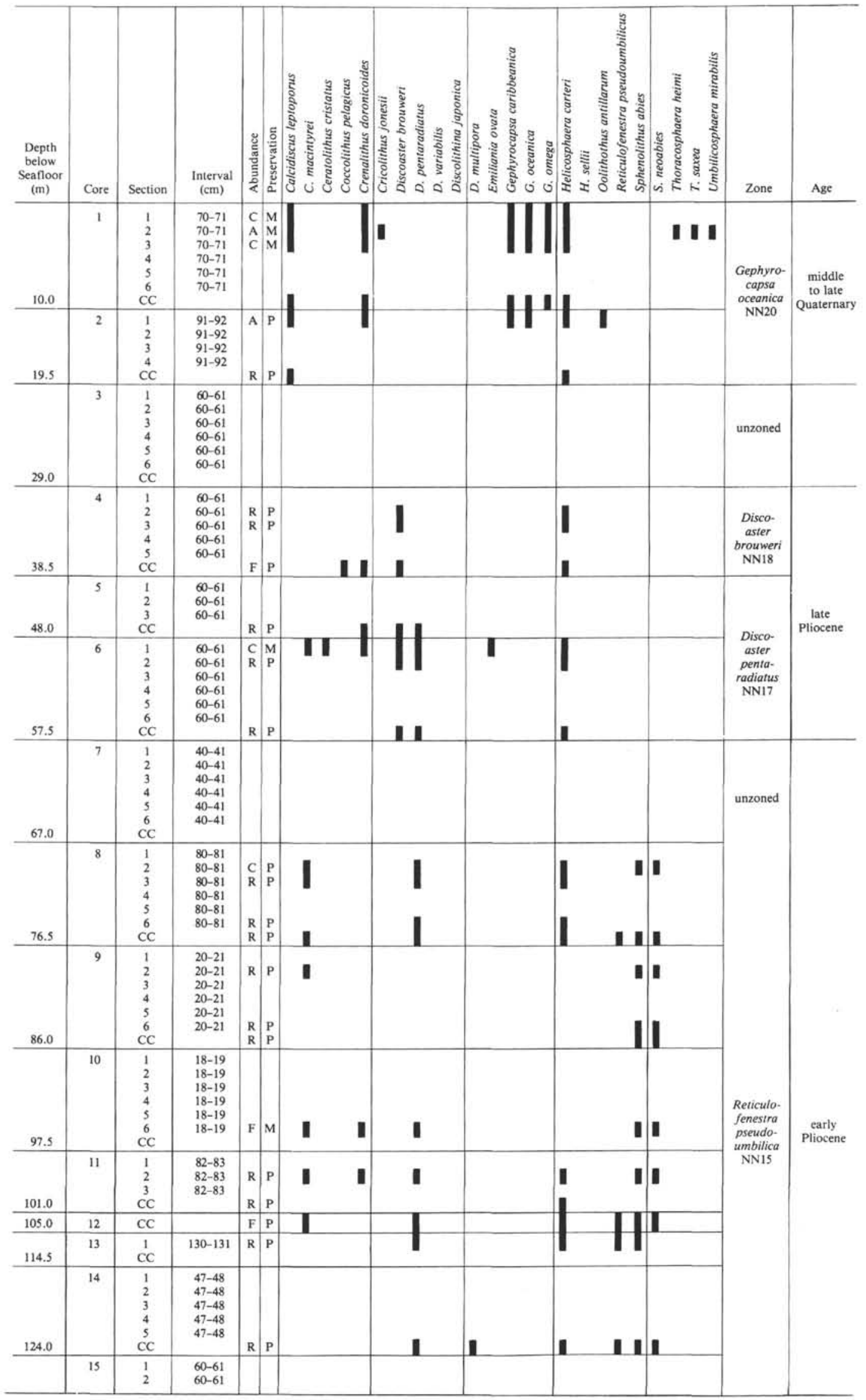


Table 12. (Continued).

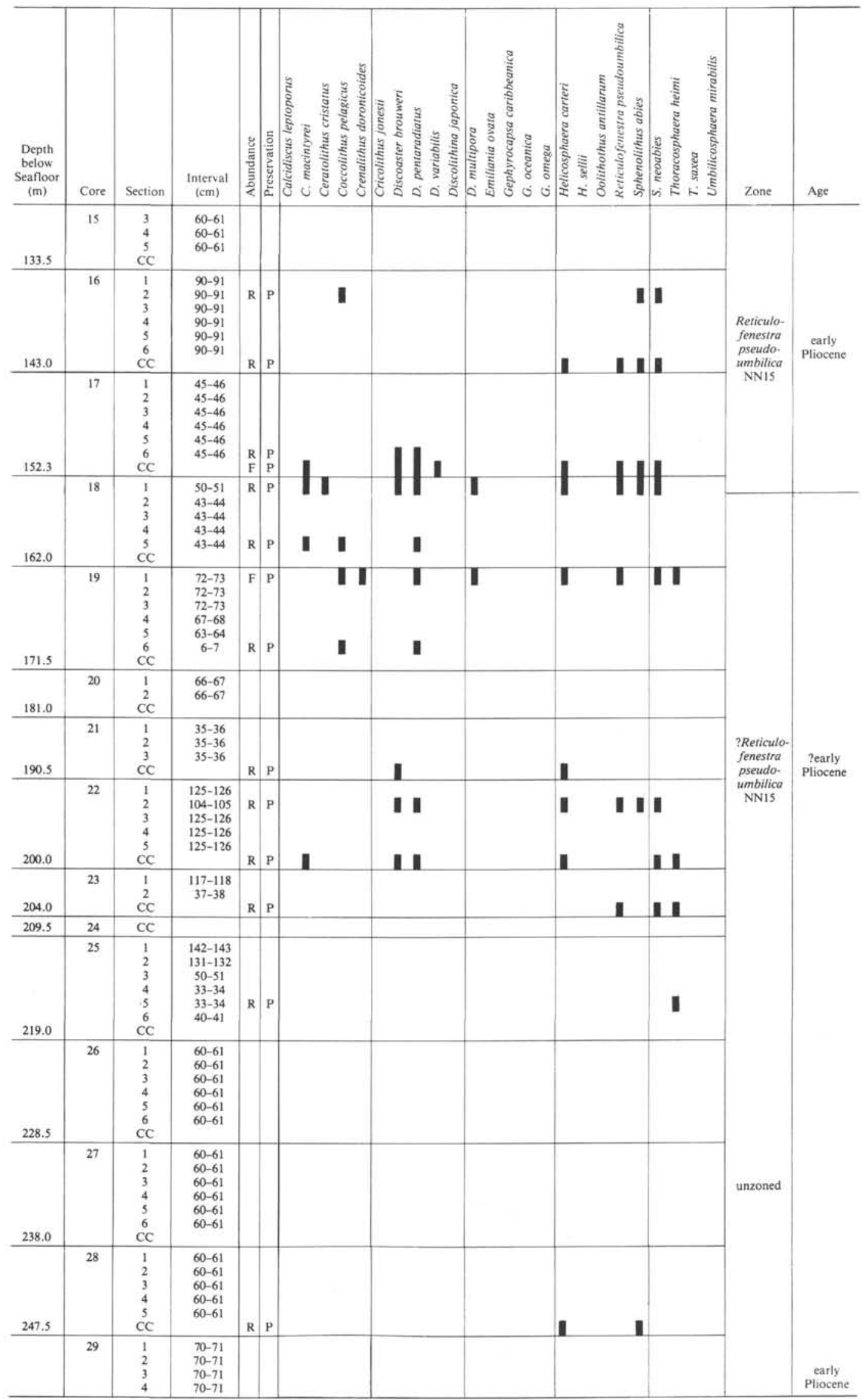


Table 12. (Continued).

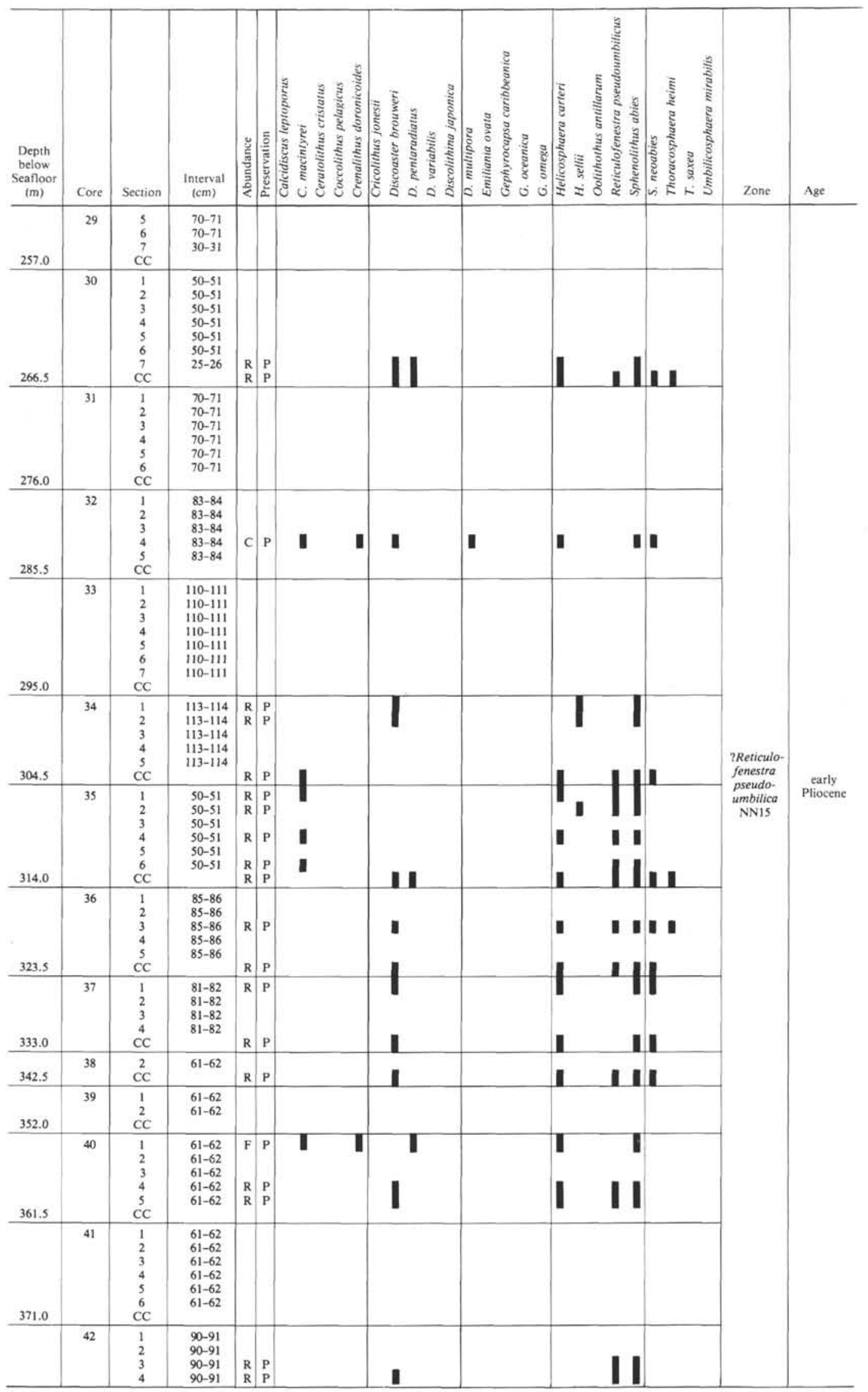


Table 12. (Continued).

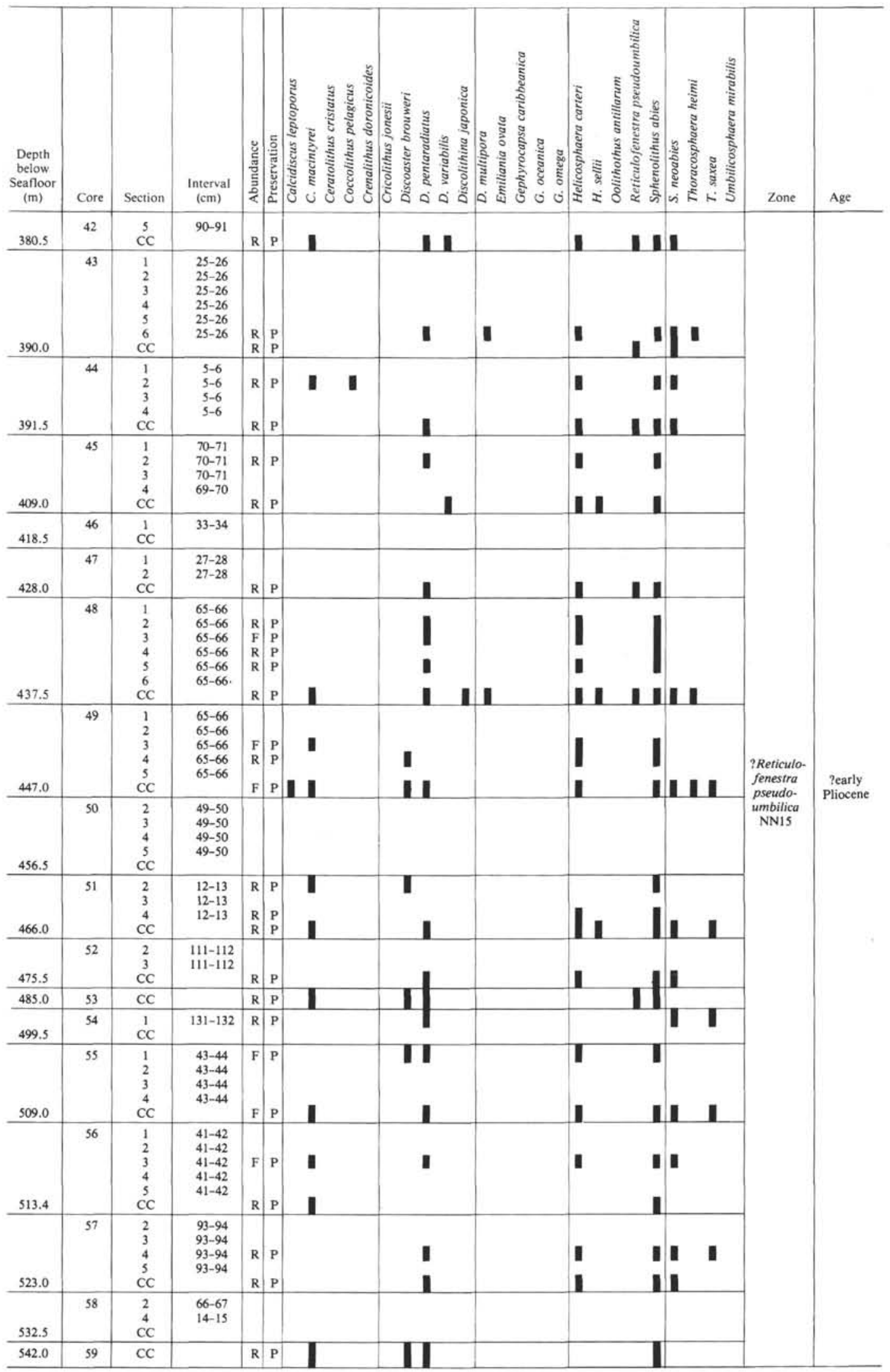


Table 13. Correlation of lithostratigraphy, biostratigraphy, and magnetostratigraphy, Hole 492.
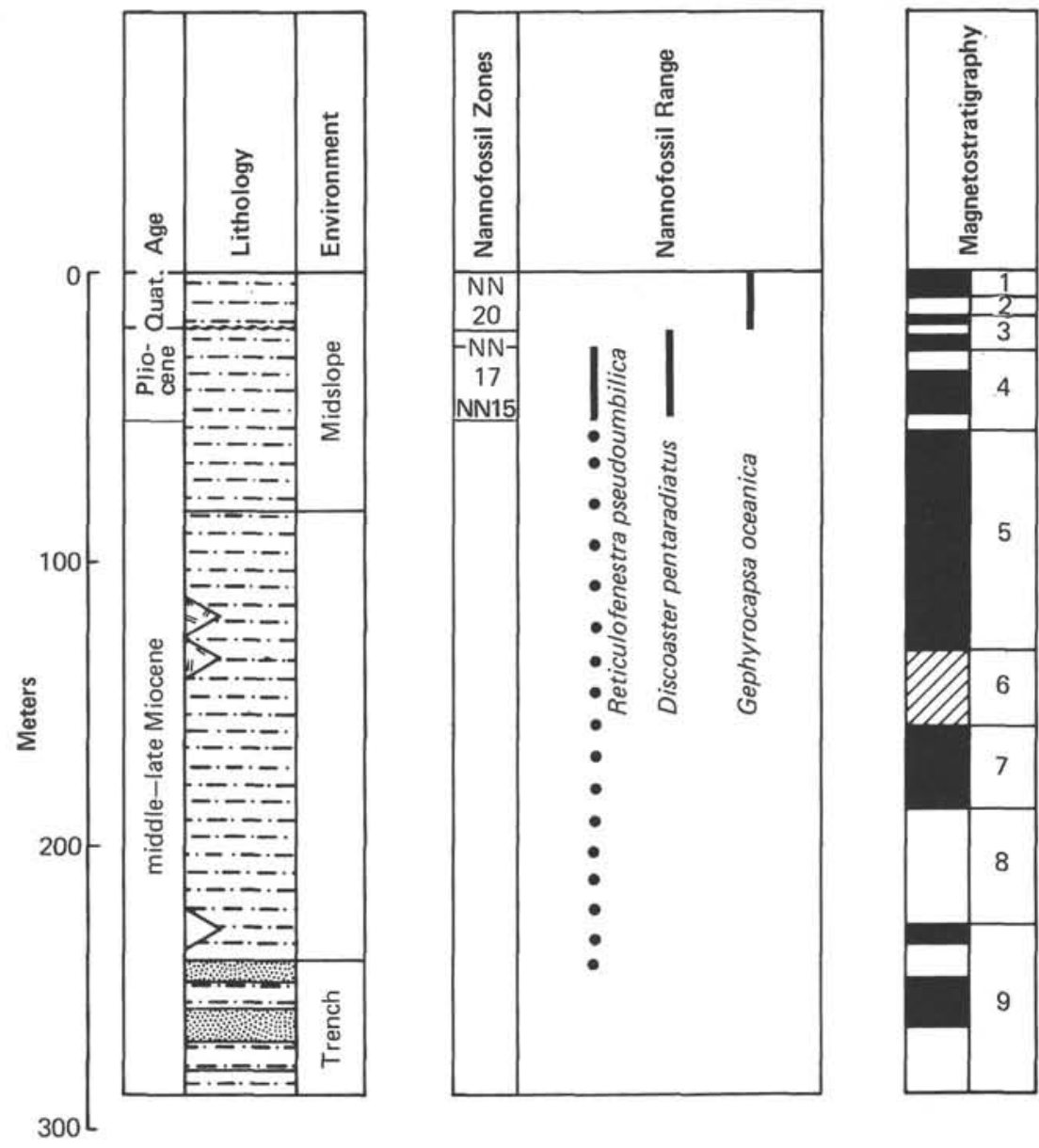
Table 14. Biostratigraphic range chart, Hole 492.

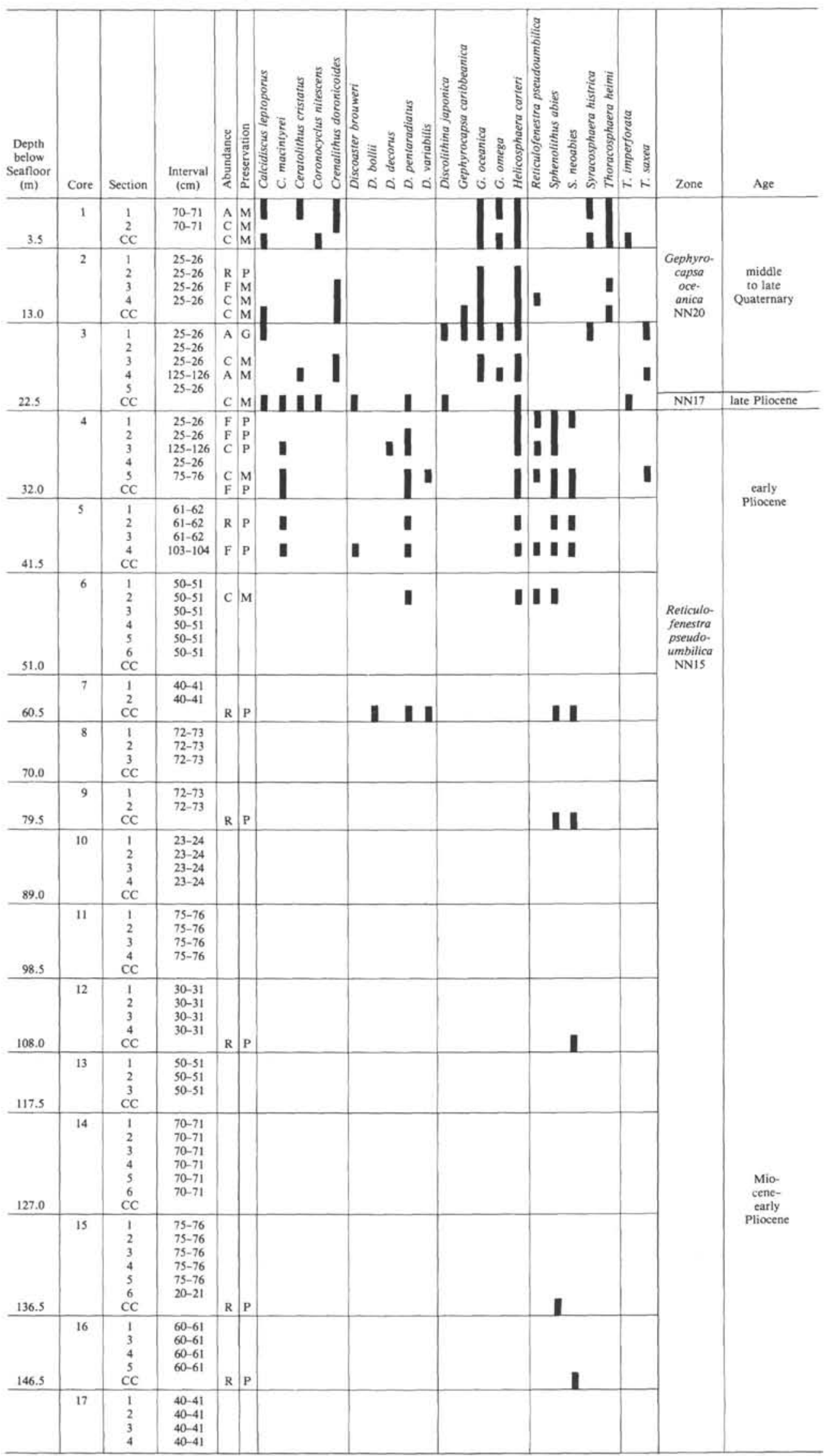


Table 14. (Continued).

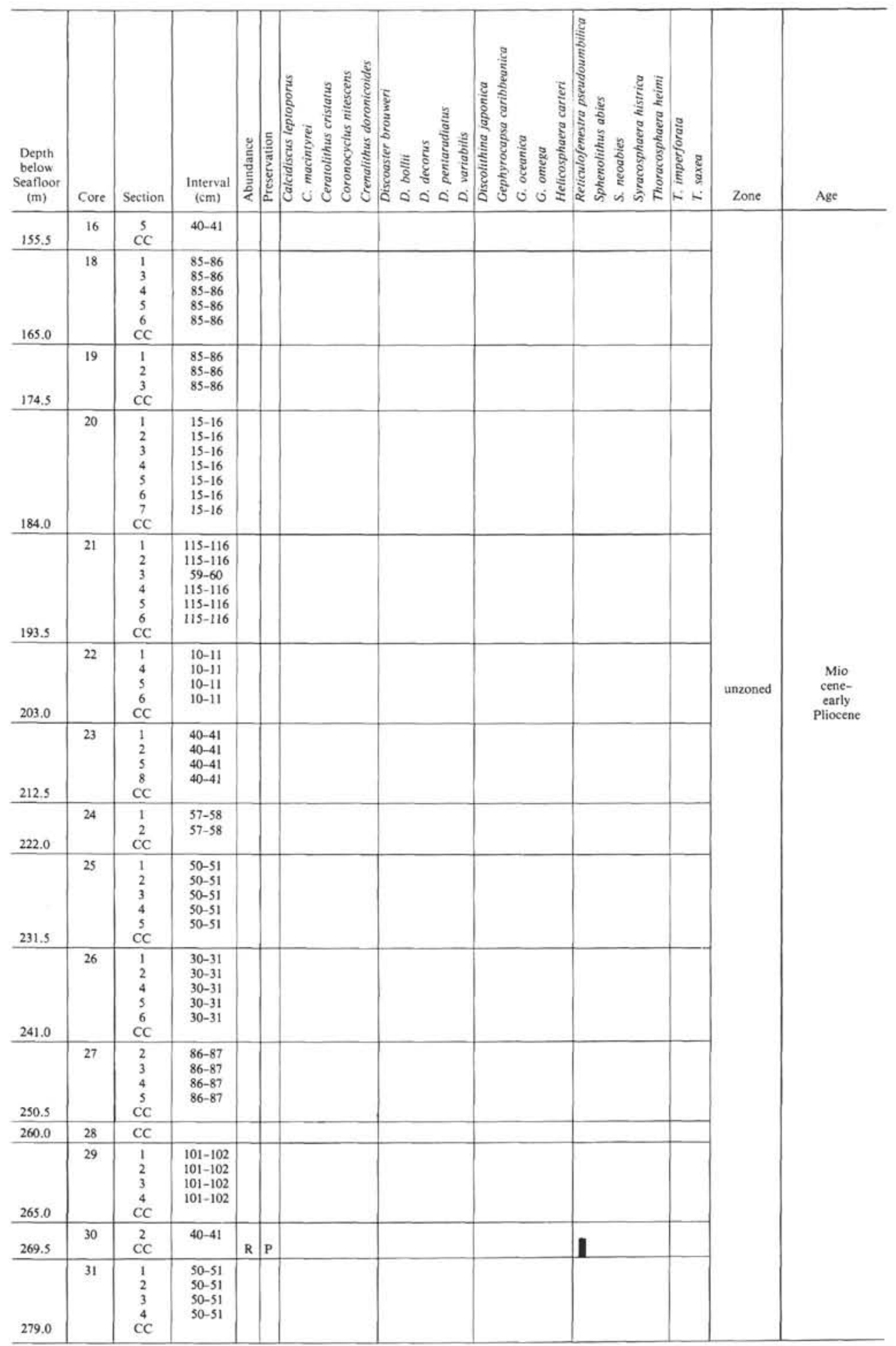


Table 15. Biostratigraphic range chart, Holes 492A and 492B.

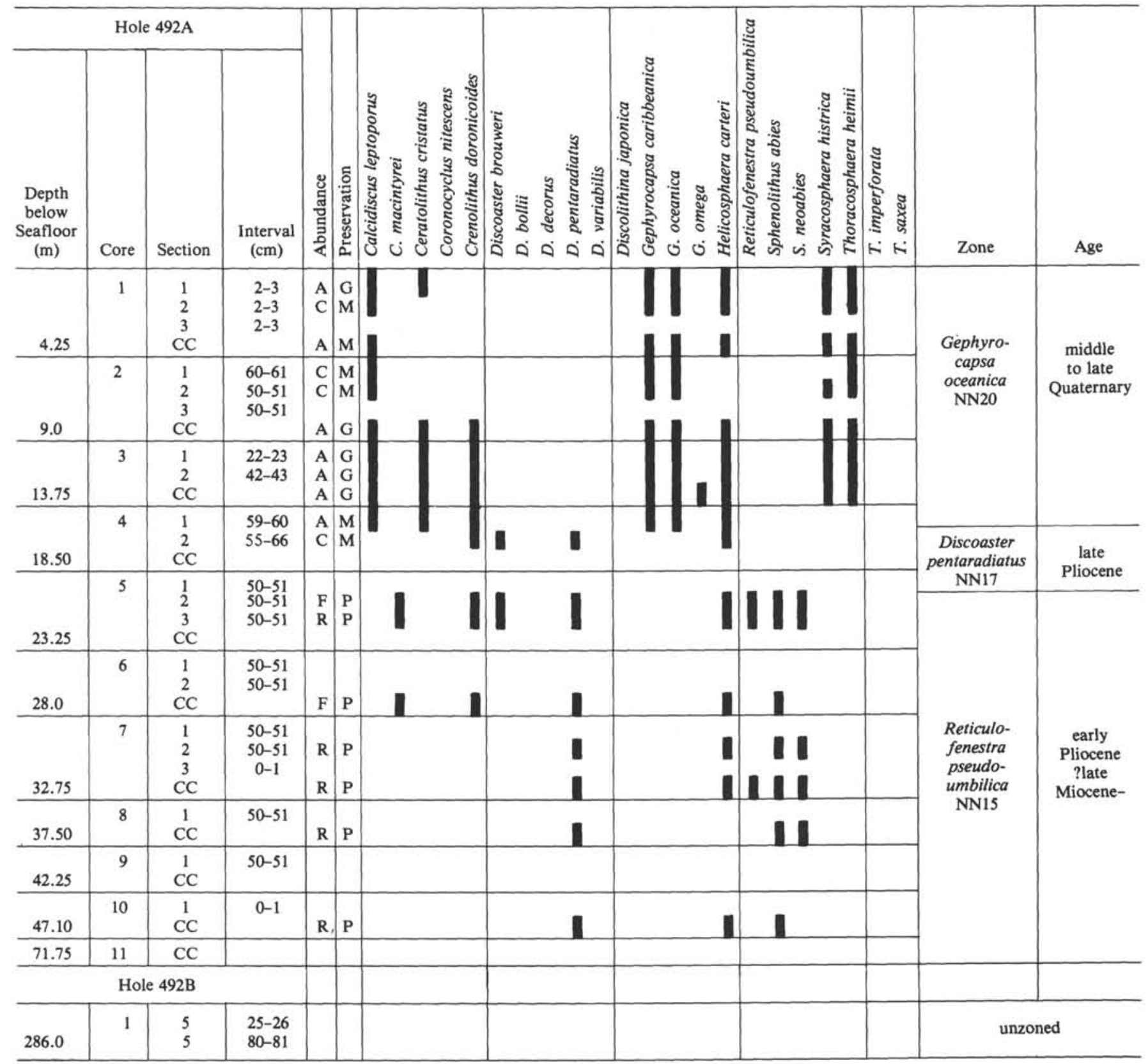


Table 16. Correlation of lithostratigraphy, biostratigraphy, and magnetostratigraphy, Hole 493.

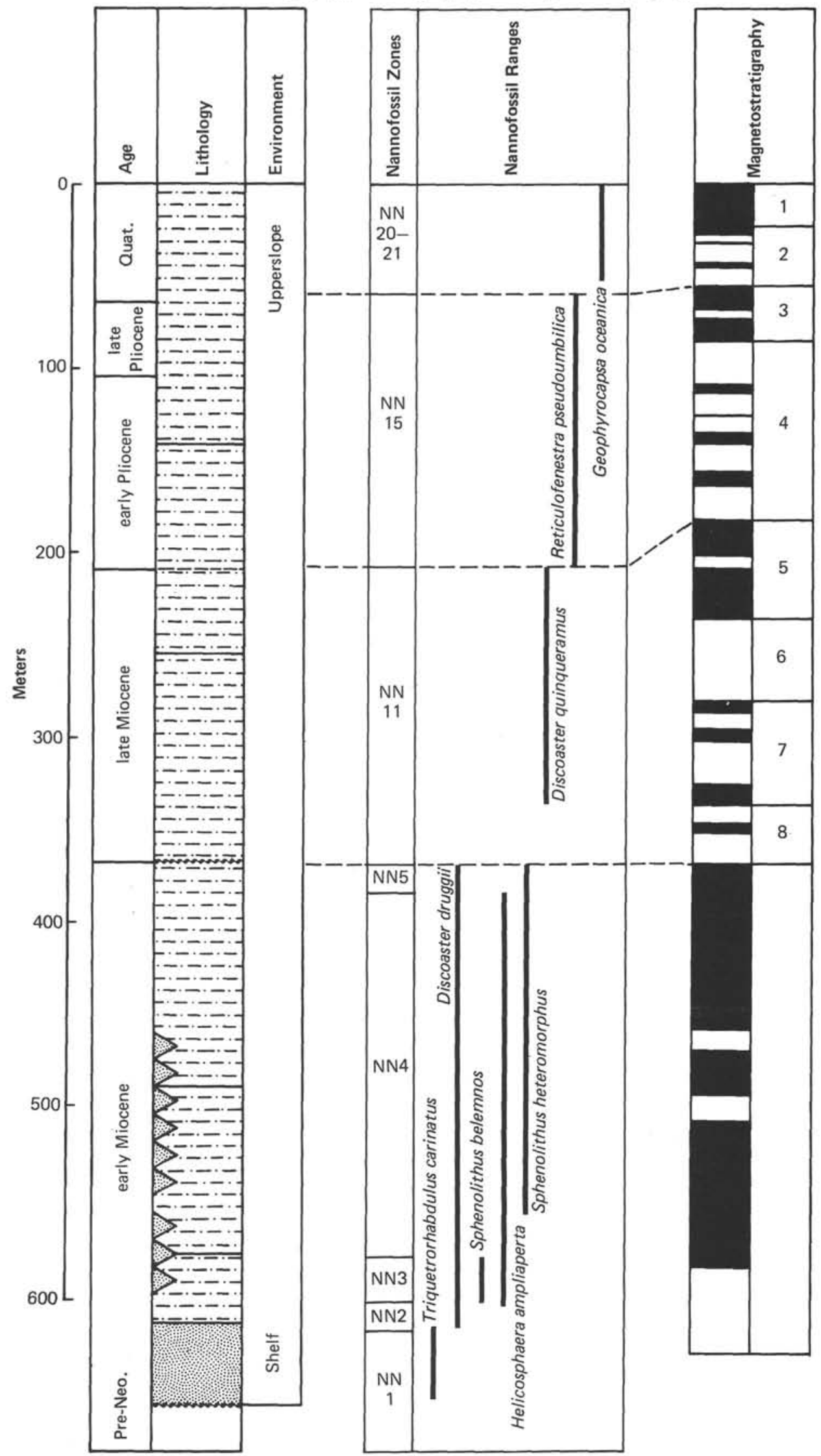


Table 17. Biostratigraphic range chart, Hole 493.

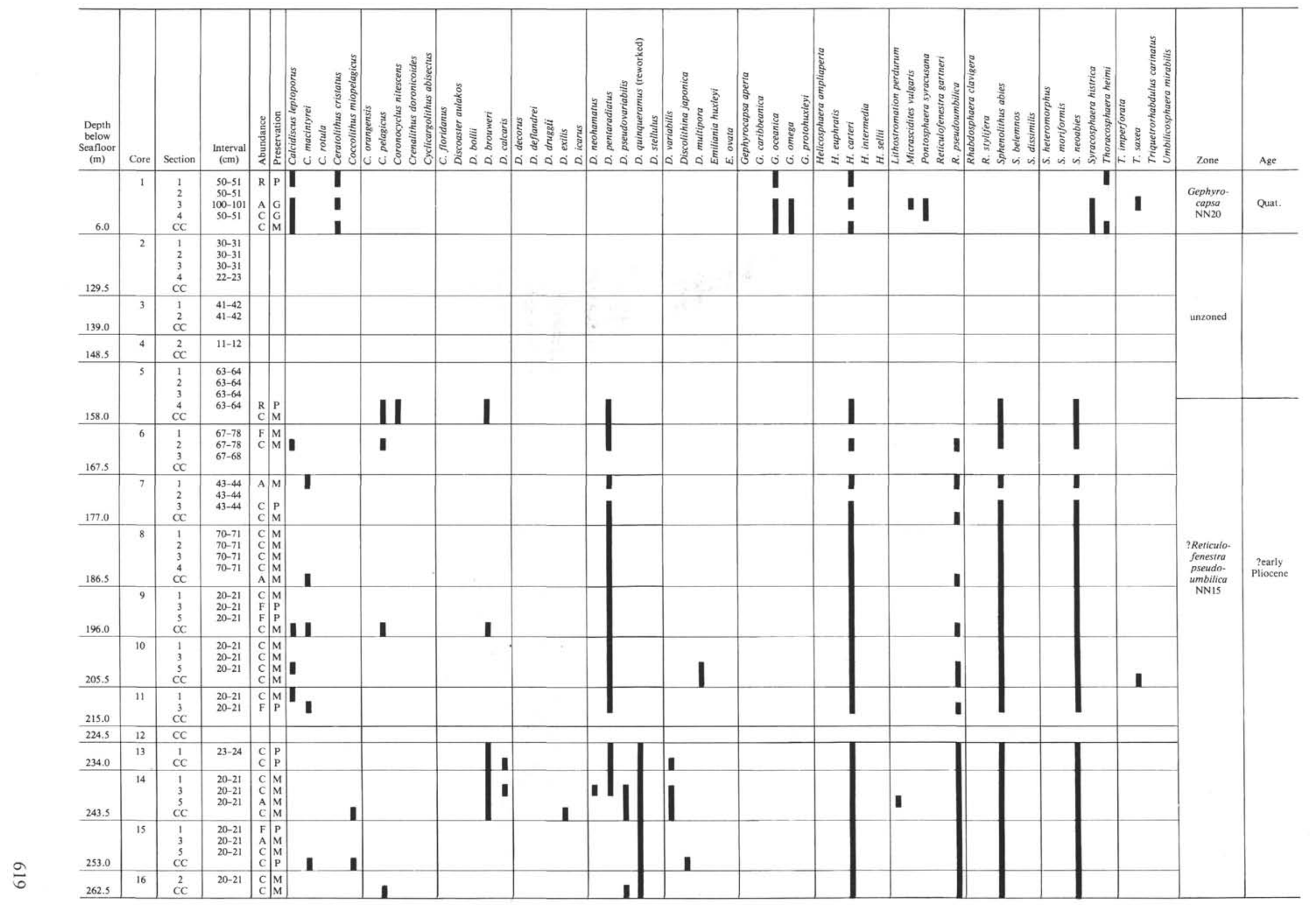




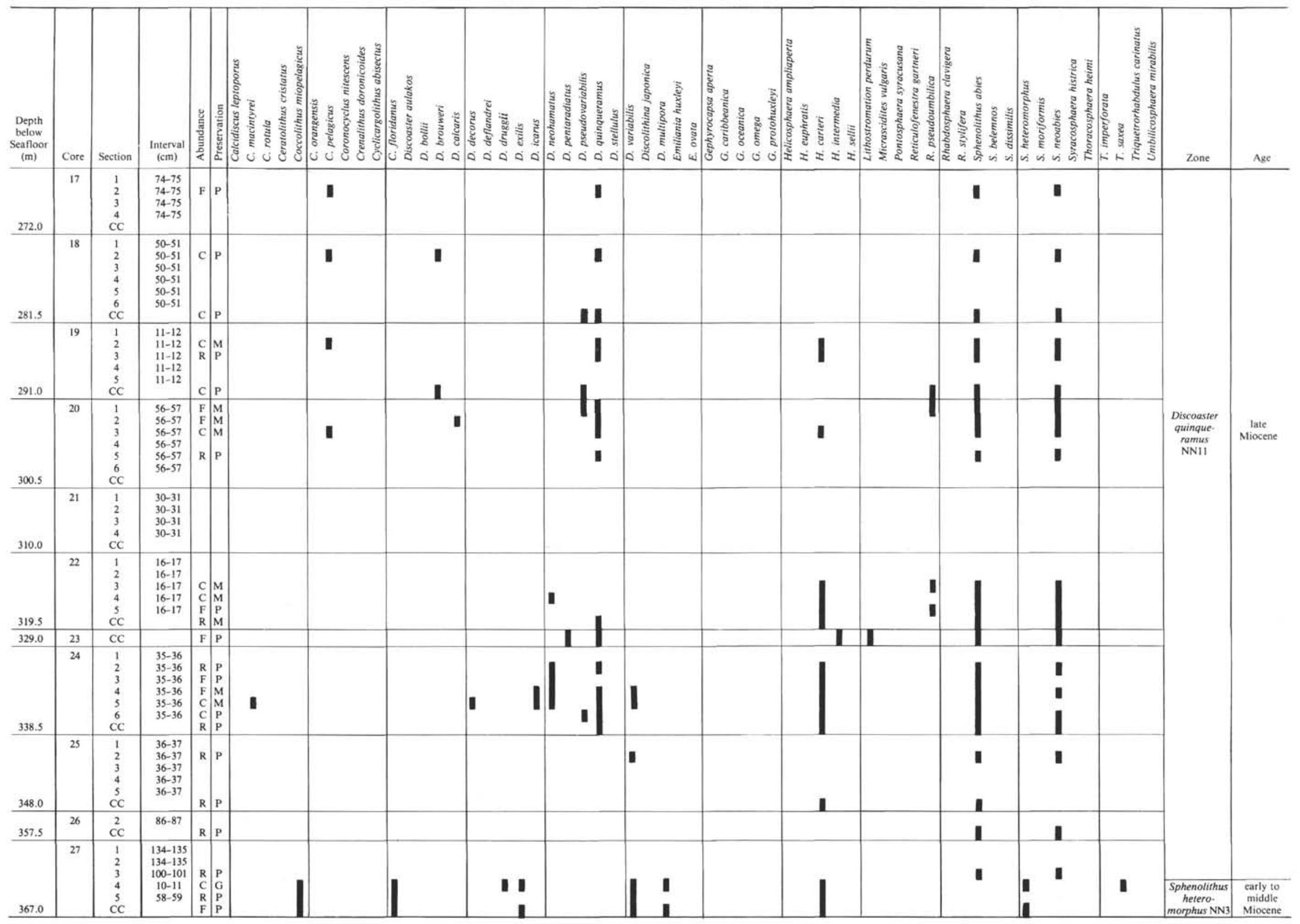


Table 17. (Continued)

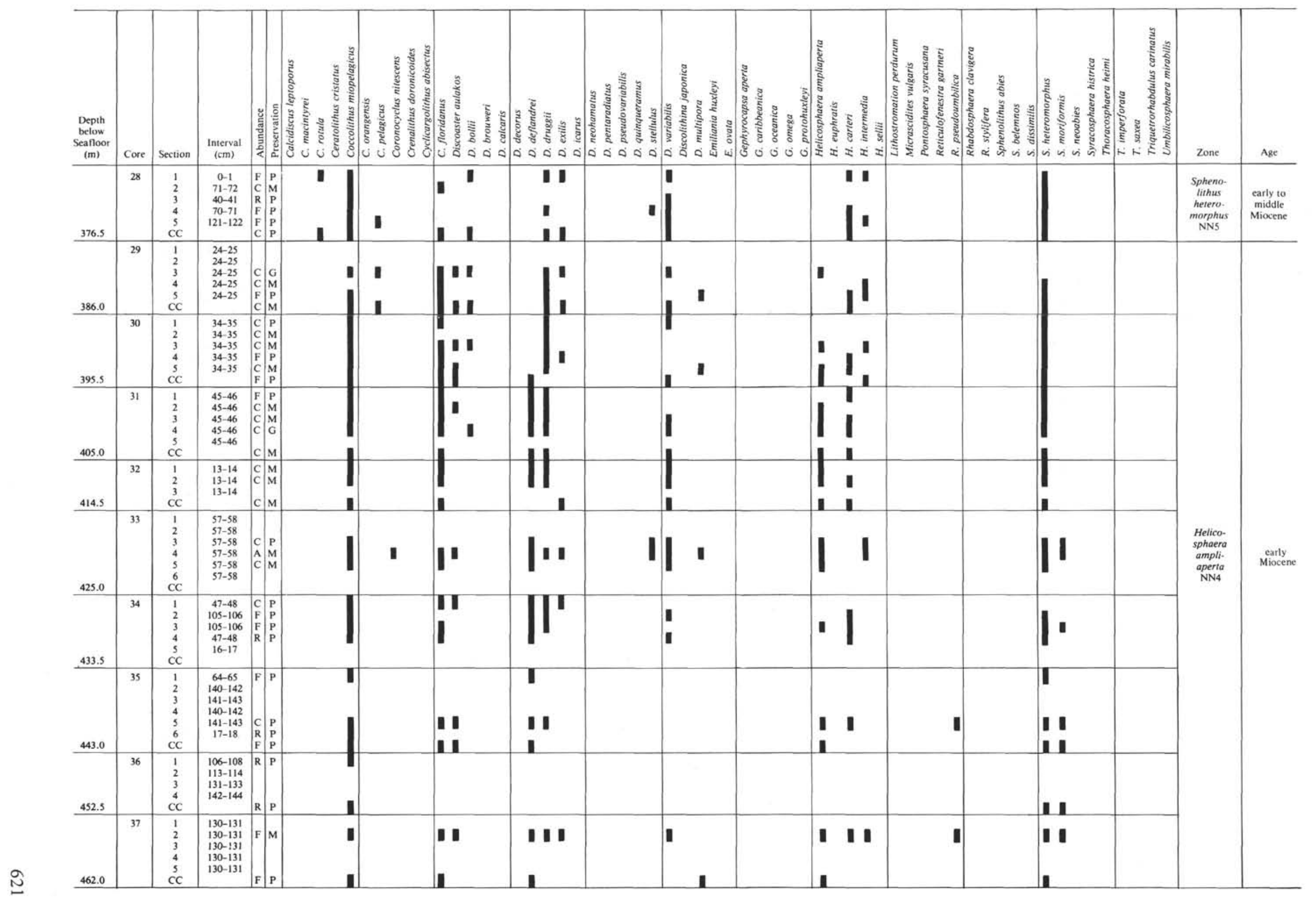

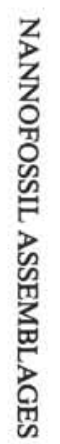




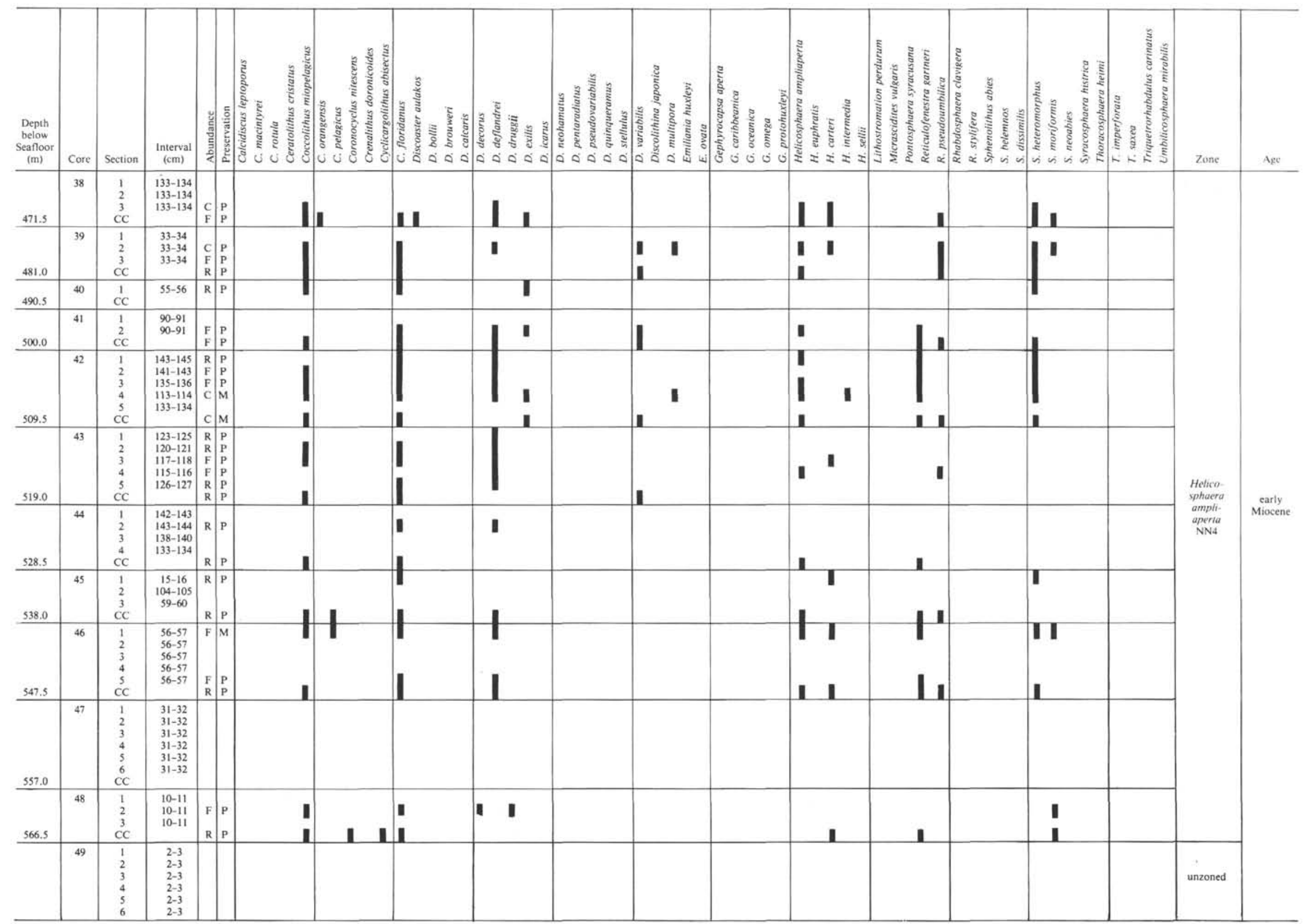


Table 17. (Continued)

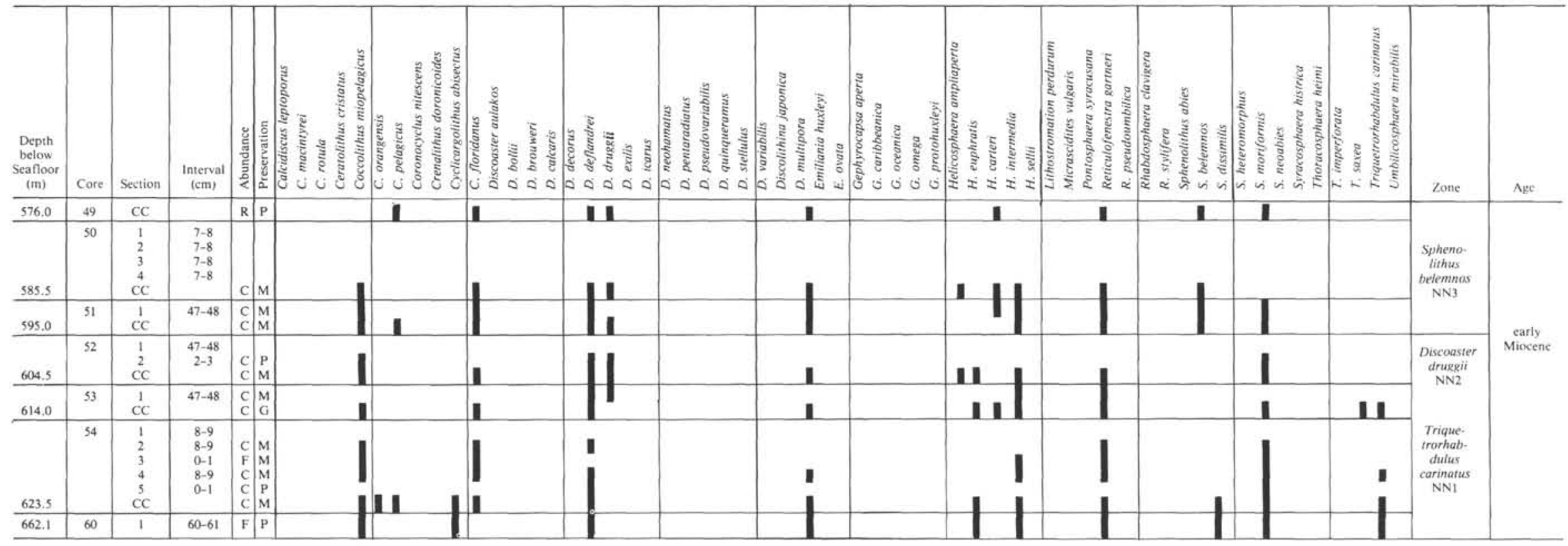


Table 18. Biostratigraphic range chart, Hole 493A.

\begin{tabular}{|c|c|c|c|c|c|c|c|c|c|c|}
\hline $\begin{array}{c}\text { Depth } \\
\text { below } \\
\text { Seafloor } \\
\text { (m) }\end{array}$ & Core & Section & $\begin{array}{c}\text { Interval } \\
(\mathrm{cm})\end{array}$ & 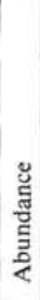 & 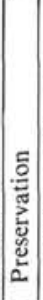 & 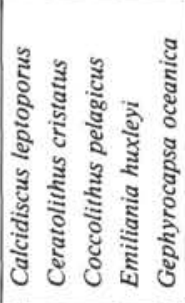 & 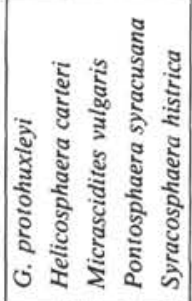 & 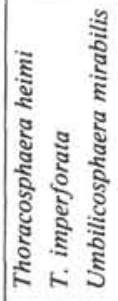 & Zone & Age \\
\hline 2.5 & 1 & $\begin{array}{c}1 \\
2 \\
\mathrm{CC}\end{array}$ & $\begin{array}{c}71-72 \\
0-1\end{array}$ & $\begin{array}{l}\mathrm{C} \\
\mathrm{C} \\
\mathrm{C}\end{array}$ & $\begin{array}{l}\mathrm{G} \\
\mathrm{G} \\
\mathrm{M}\end{array}$ & & & & \multirow{3}{*}{$\begin{array}{c}\text { Emiliania } \\
\text { huxleyi } \\
\mathrm{NN} 21\end{array}$} & \multirow{3}{*}{$\begin{array}{c}\text { late } \\
\text { Quaternary }\end{array}$} \\
\hline \multirow[t]{2}{*}{12.0} & 2 & $\begin{array}{c}1 \\
2 \\
3 \\
\text { CC }\end{array}$ & $\begin{array}{c}2-3 \\
32-33 \\
2-3\end{array}$ & $\begin{array}{l}\mathrm{C} \\
\mathrm{C}\end{array}$ & $\begin{array}{c}\mathrm{M} \\
\mathrm{P}\end{array}$ & 1 & ! & 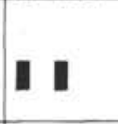 & & \\
\hline & 3 & $\mathrm{CC}$ & & C & $\mathrm{P}$ & & & & & \\
\hline
\end{tabular}


Table 19. Biostratigraphic range chart, Hole 493B.

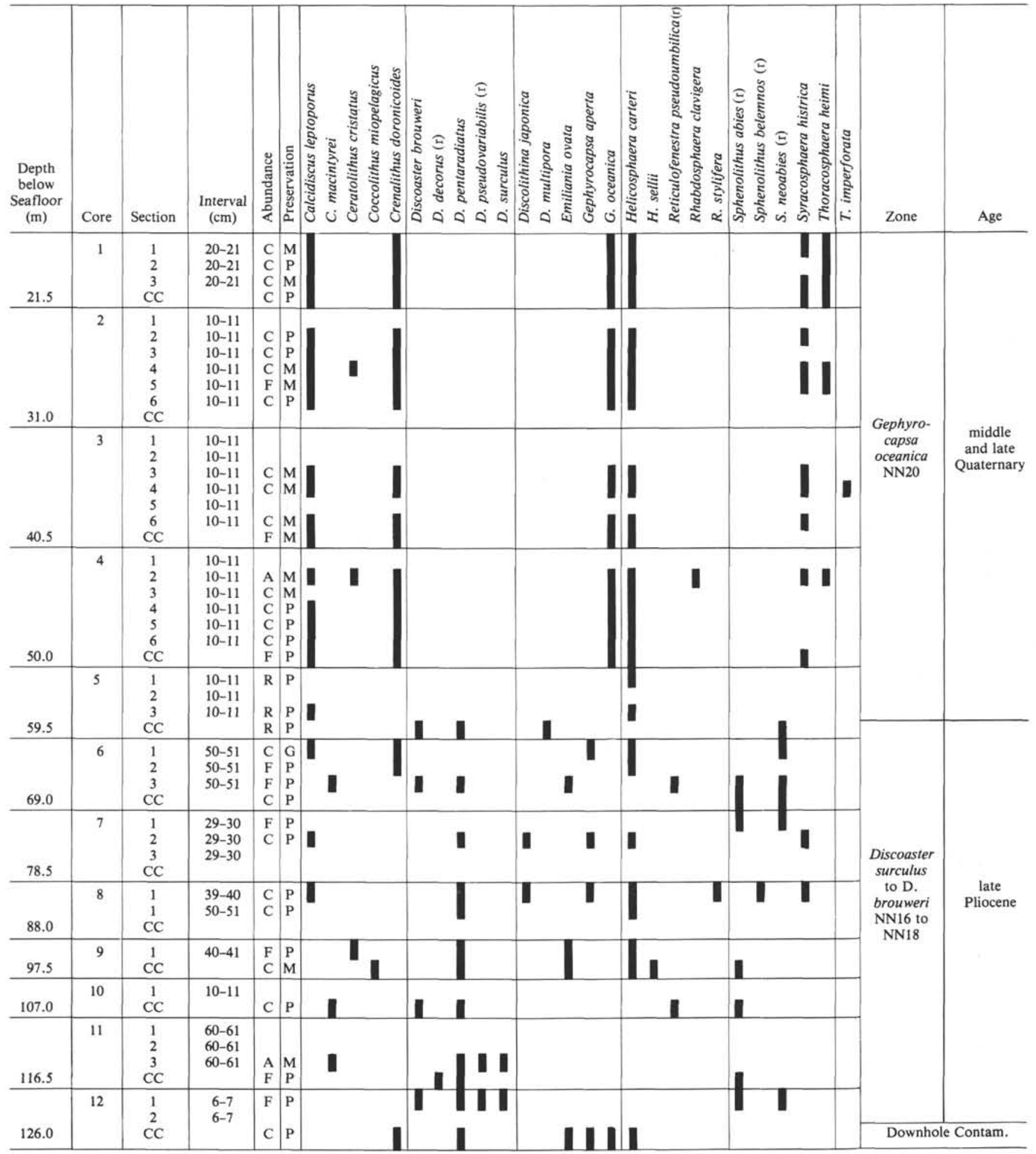

Note: $\mathrm{r}=$ reworked. 

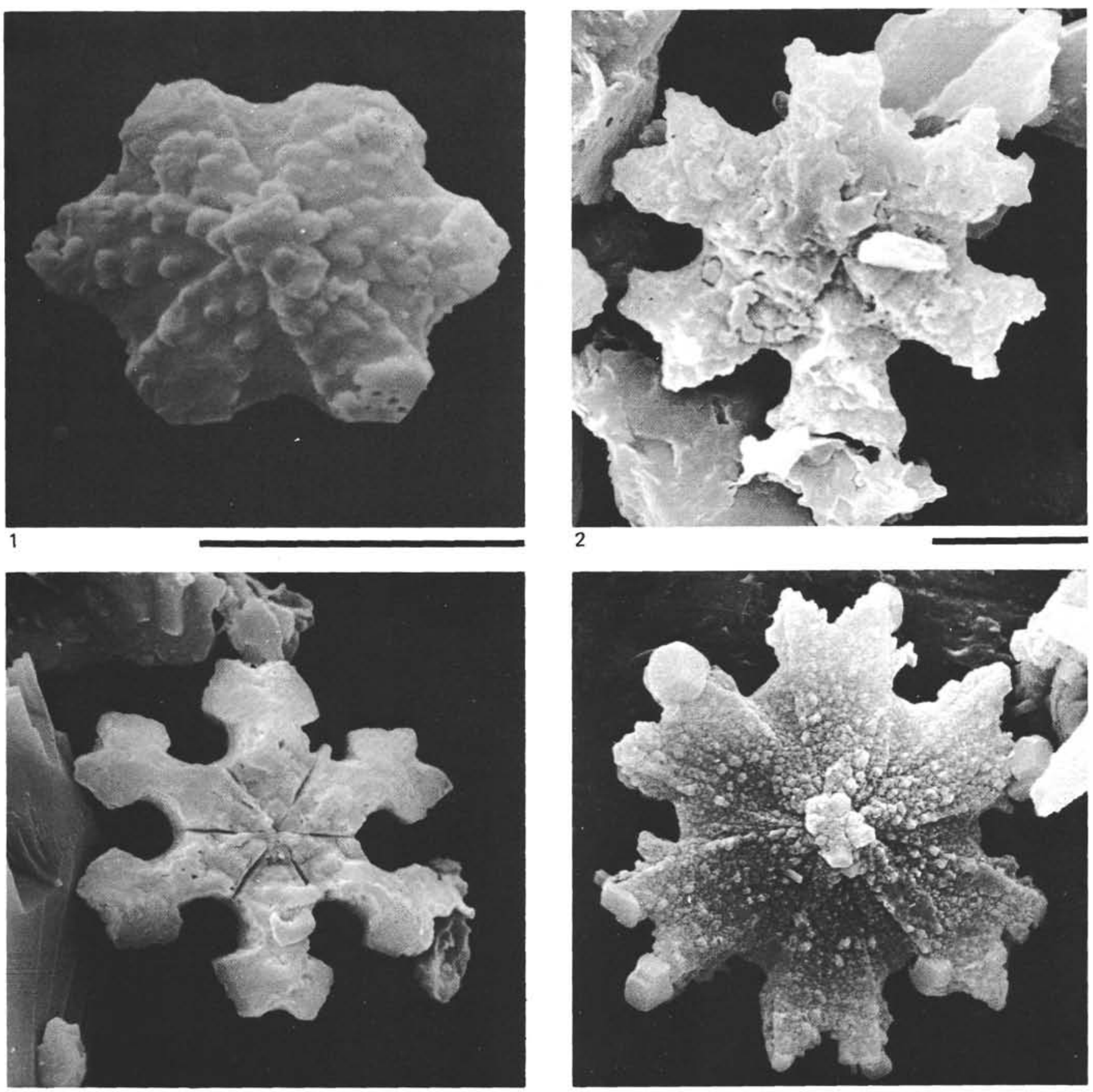

3

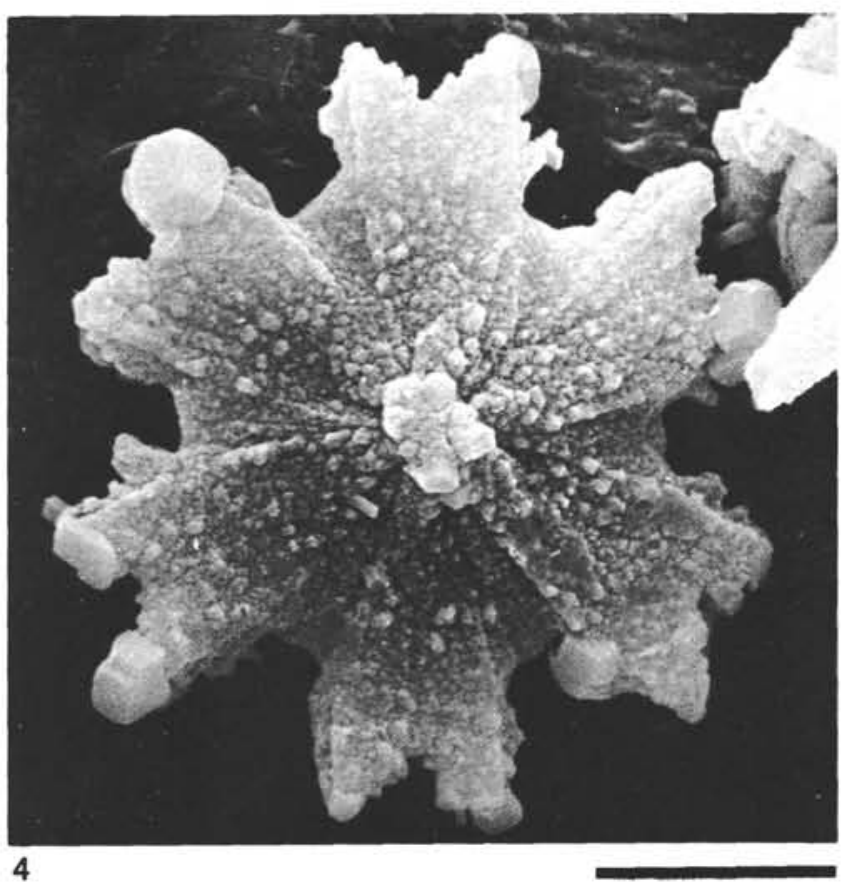

Plate 1 (all figures plane views, SEM; scale bar $=5 \mu \mathrm{m}$ ). 1. Discoaster stellulus Gartner. Sample 498A-10-2. 2. Discoaster deflandrei Bramlette and Riedel, corroded specimen. Sample 493-55,CC. 3. Discoaster deflandrei Bramlette and Riedel, well-preserved specimen. Sample 493-55,CC. 4. Discoaster calculosus Bukry. Sample 493-33-4, 57-58 cm.

Note: The following abbreviations are used in the plate captions: $\mathrm{LM}=$ light microscopy, normal light, $\mathrm{PHC}=$ phase contrast, $\mathrm{XNIC}=$ polarized light, TEM = transmission electron microscopy, SEM = scanning electron microscopy. 

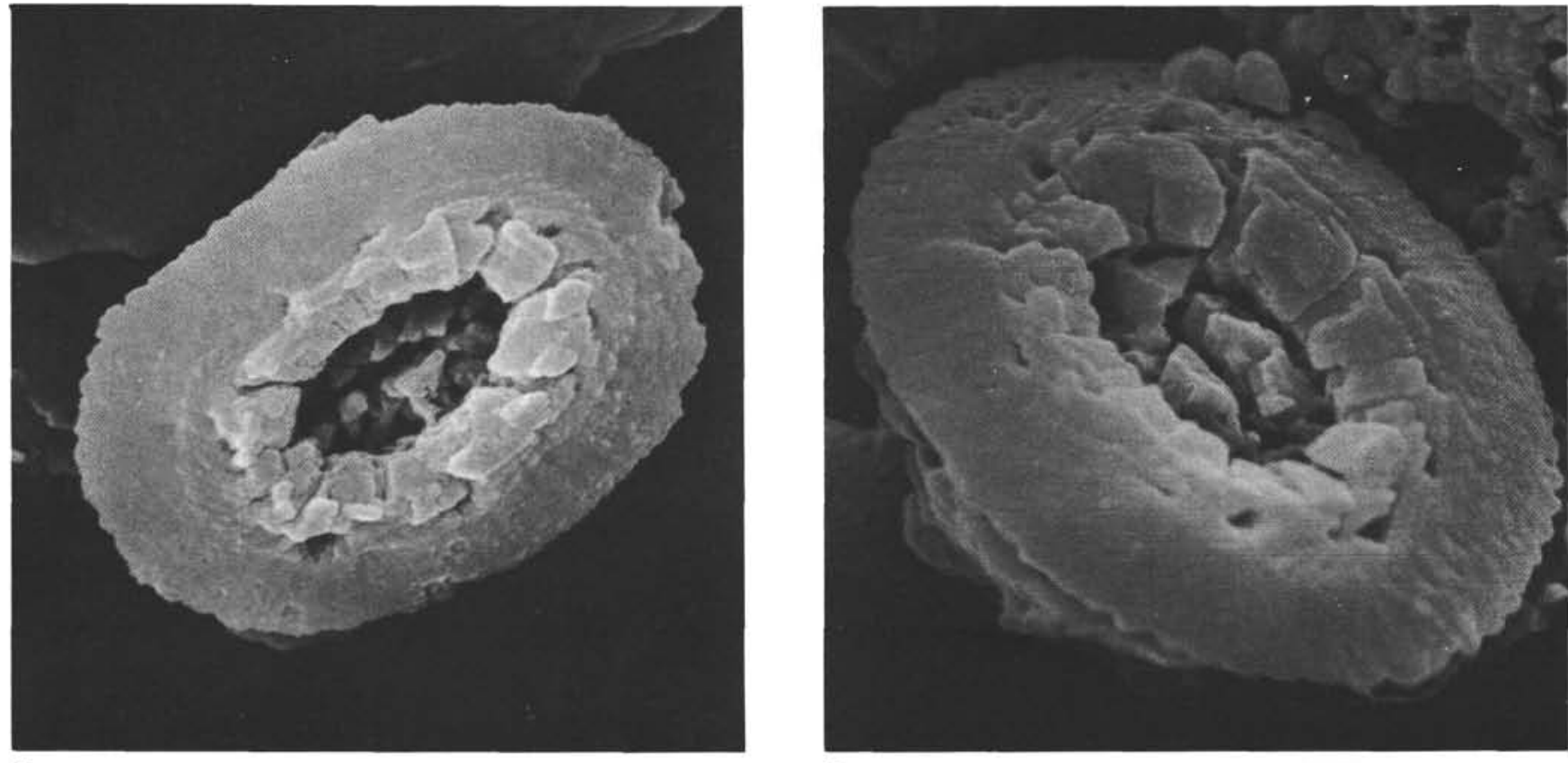

1

2
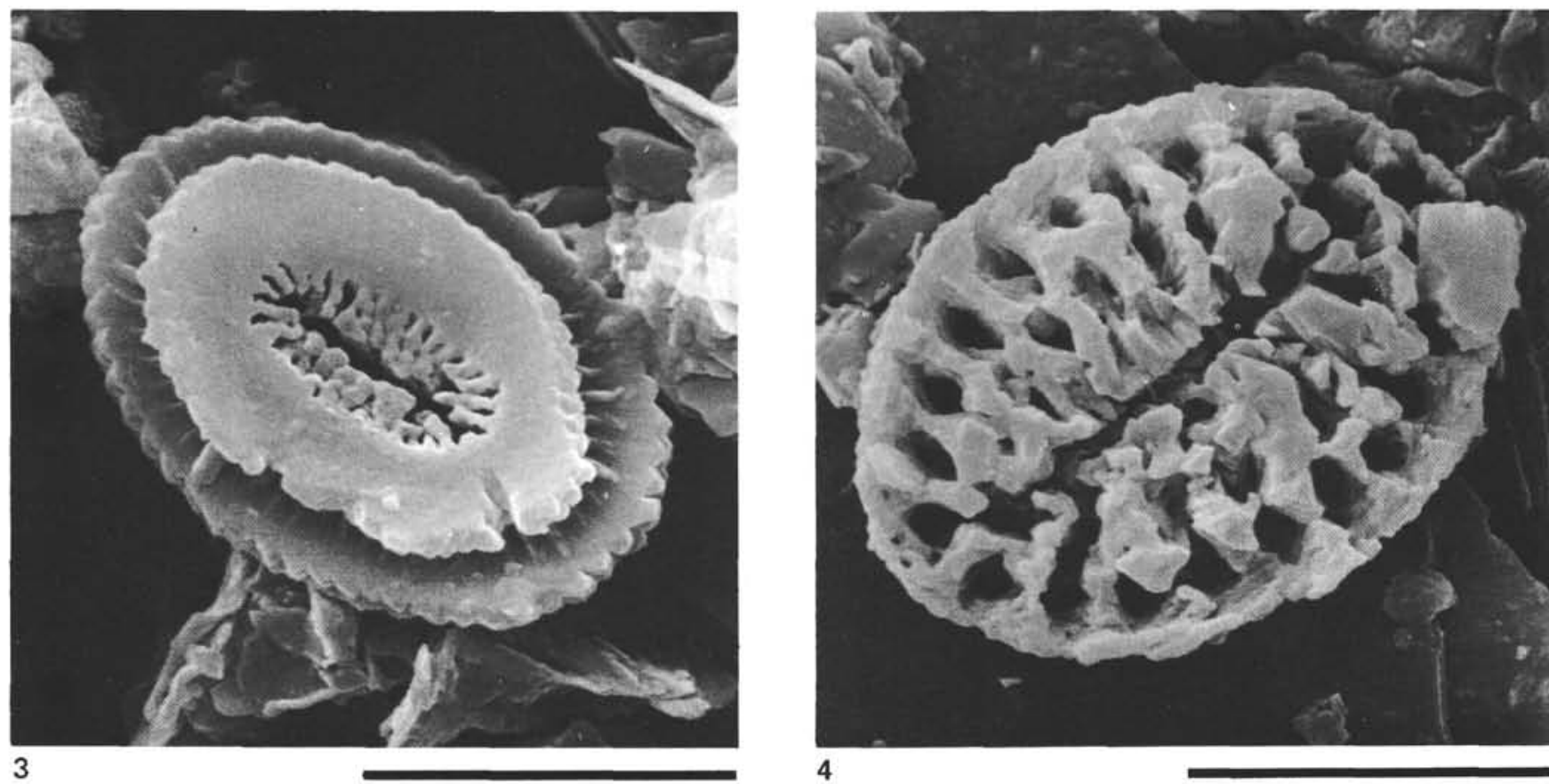

Plate 2 (Section 493-53,CC; scale bar $=5 \mu \mathrm{m}$ ). 1. Reticulofenestra gartneri Roth and Hay, distal view, SEM. 2. Reticulofenestra gartneri Roth and Hay, distal view, SEM. 3. Reticulofenestra gartneri Roth and Hay, proximal view, SEM. 4. Discolithina multipora (Kamptner) Martini, distal side, SEM. 

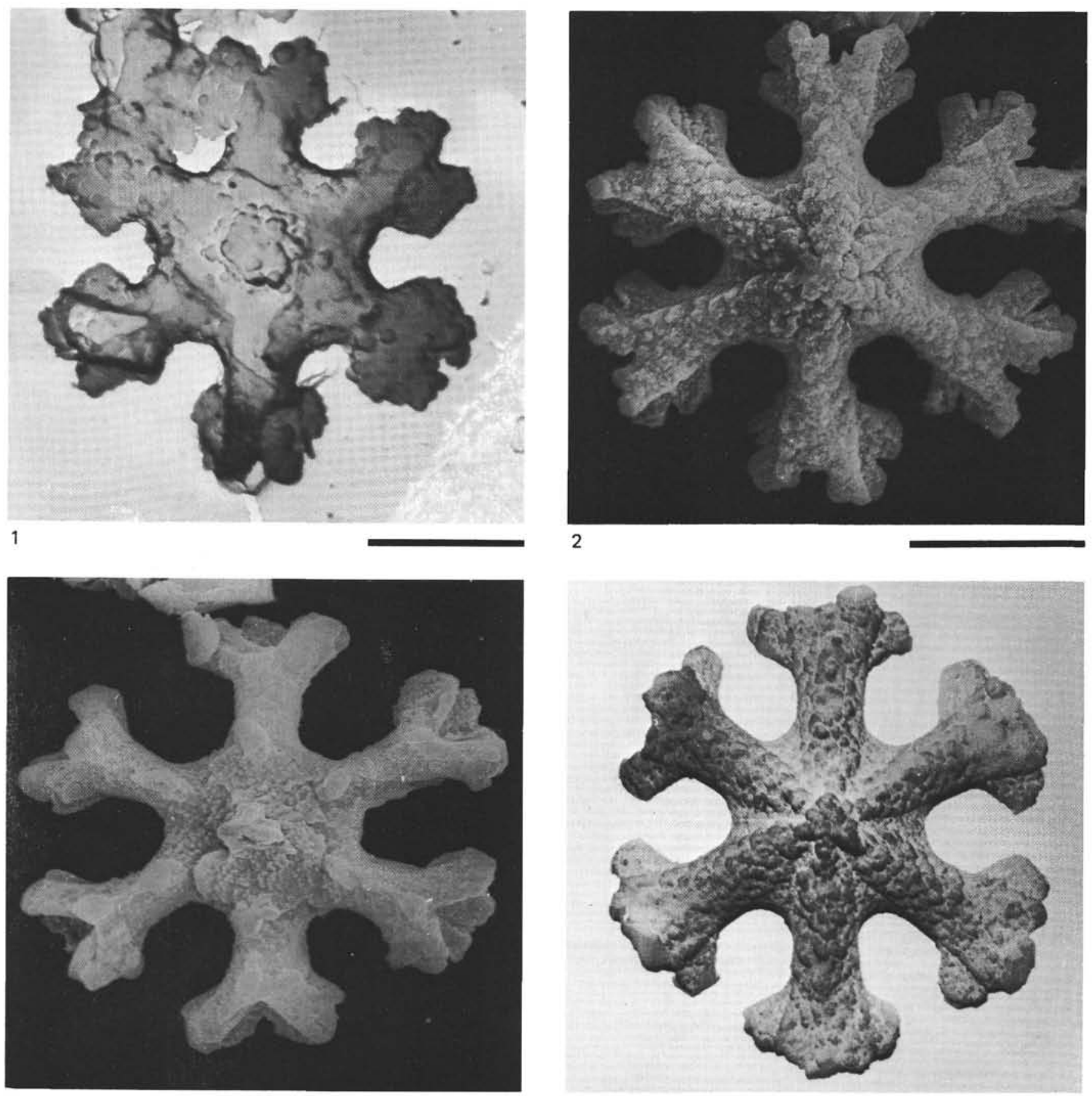

3

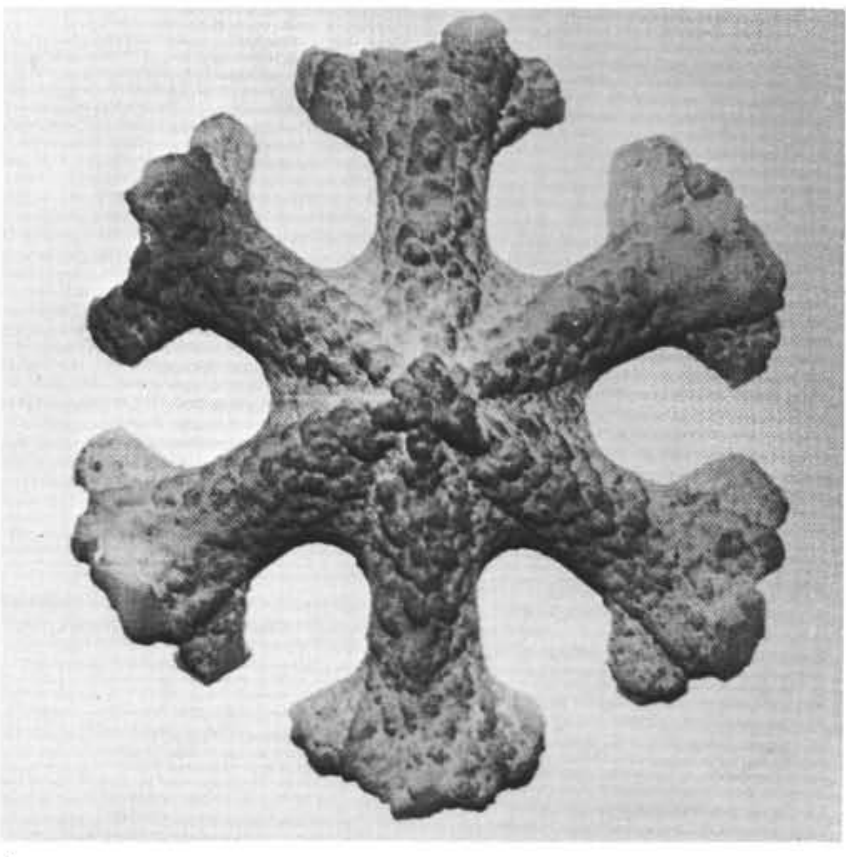

4

Plate 3 (scale bar $=5 \mu \mathrm{m}$ ). 1. Discoaster deflandrei Bramlette and Riedel, plane view, TEM. Sample 489-1,CC. 2. Discoaster deflandrei Bramlette and Riedel, plane view of partly corroded specimen, SEM. Sample 493-33-4, 57-58 cm. 3. Discoaster icarus Stradner, plane view, SEM. Sample 493-33-4, 57-58 cm. 4. Discoaster icarus Stradner, plane view, SEM, reversed print. Sample 493-33-4, 57-58 cm. 


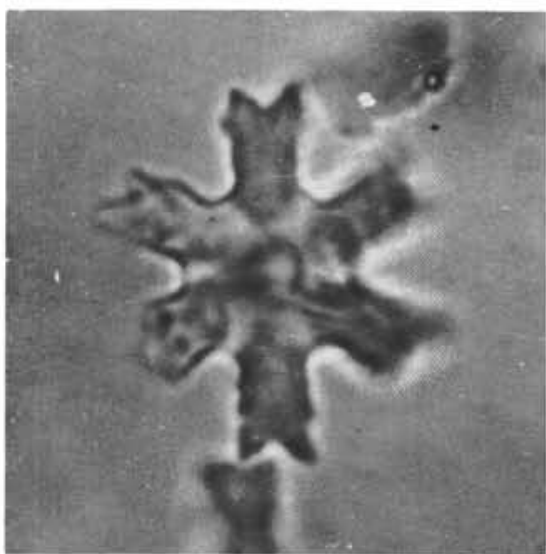

1

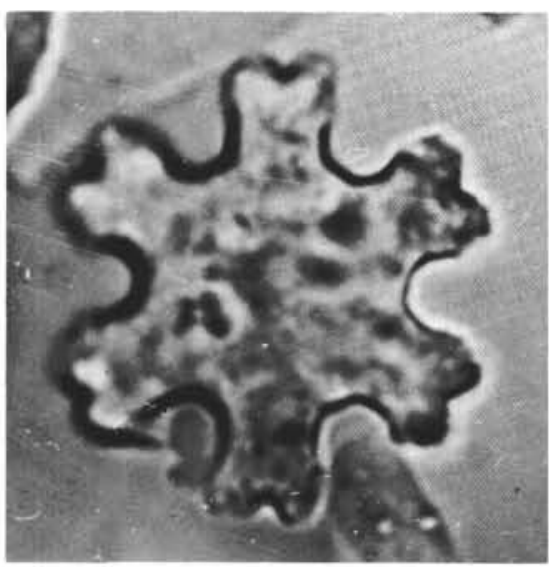

4

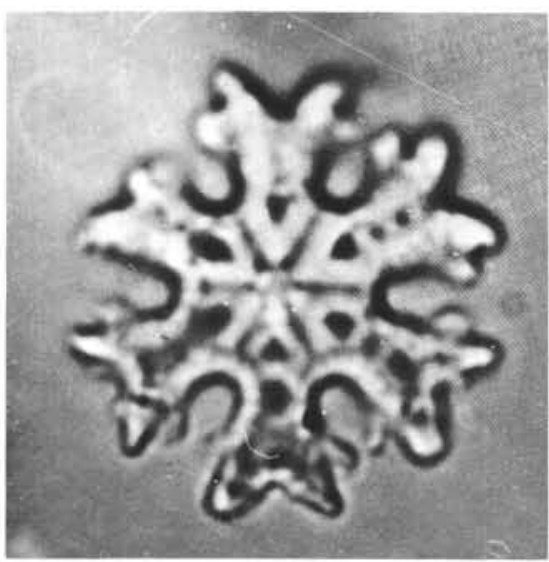

7

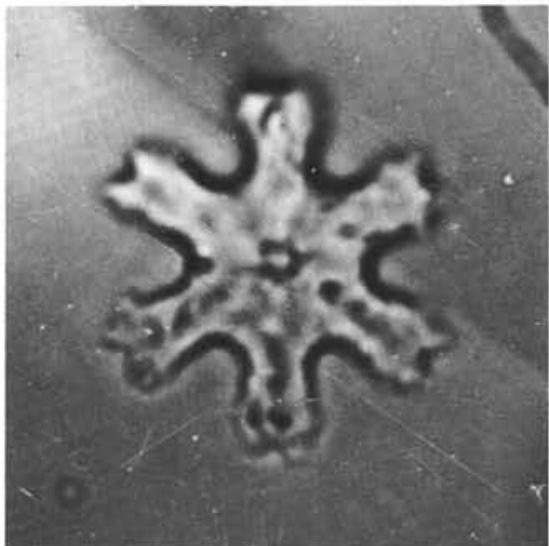

2

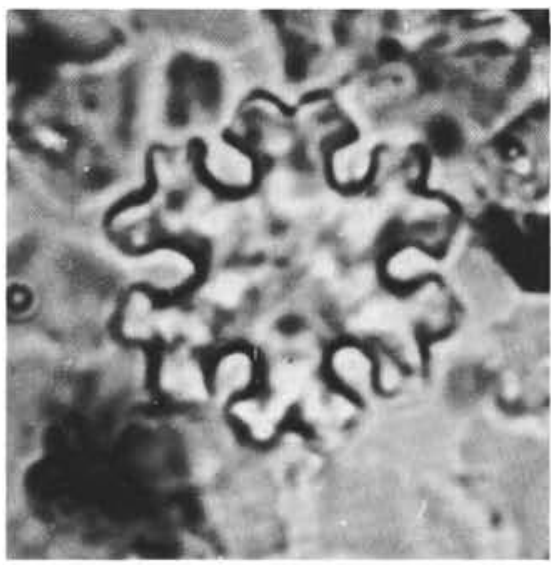

5

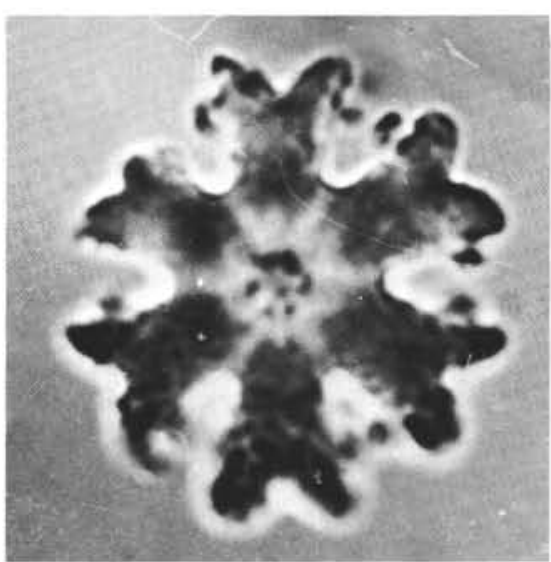

8

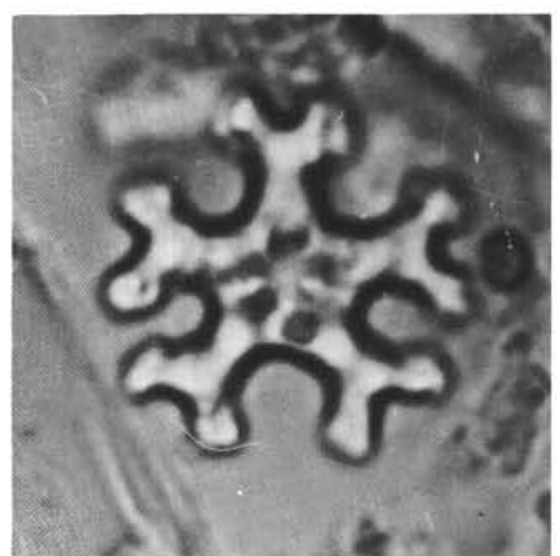

3

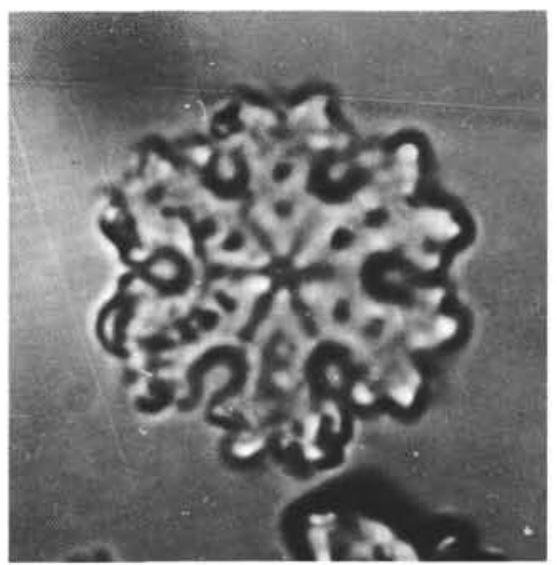

6

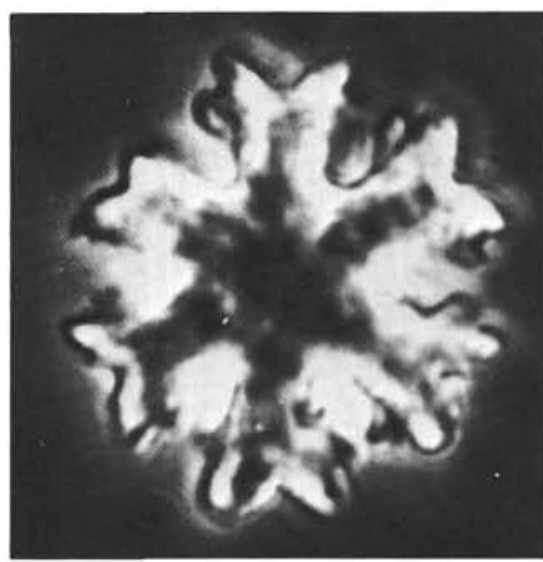

9

Plate 4. Photomicroscopic pictures of early Miocene discoasters (scale bar $=5 \mu \mathrm{m}$ ). Figures 1-8 NL, Figure 9 PHC. Sample 489A-12,CC (Figs. 2 , 6, 7-9); Sample 493-33-4, 57-58 cm (Fig. 3, 5); Sample 493-52,CC (Figs. 1, 4). Discoaster calculosus Bukry (Figs. 1, 2, 4, 7-9). Discoaster deflandrei Bramlette and Riedel (Figs. 3, 5). 


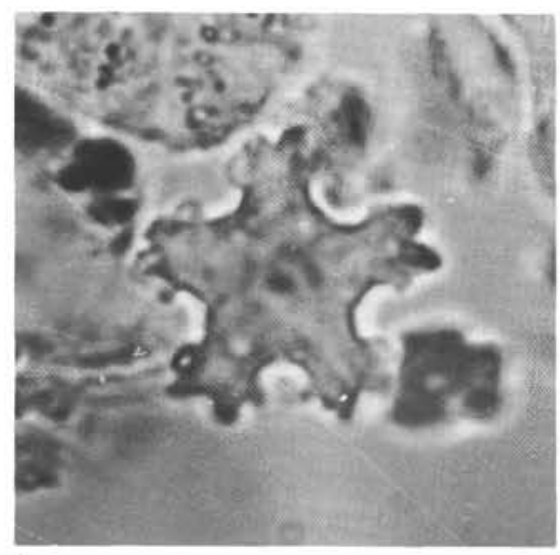

1

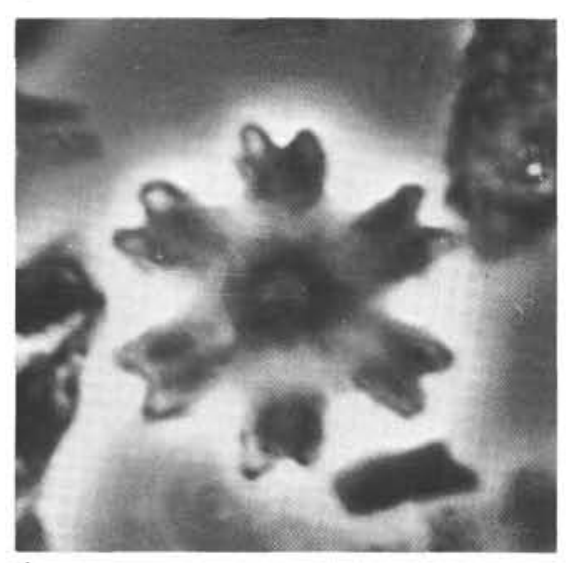

4

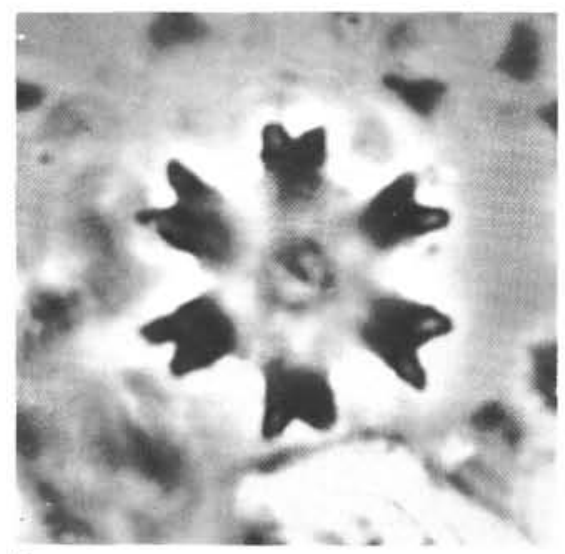

7

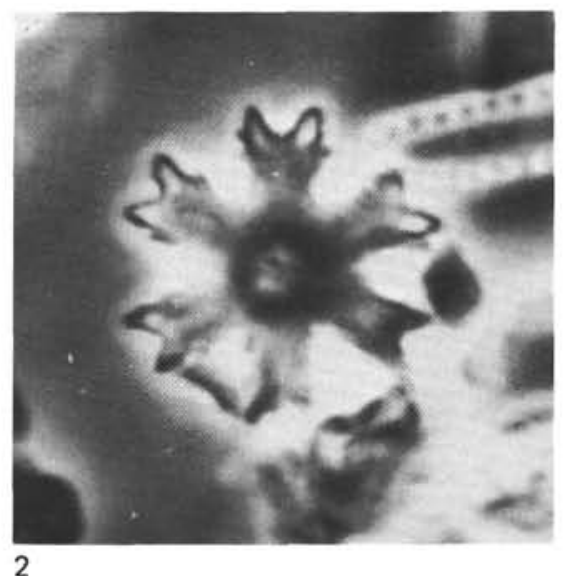

2

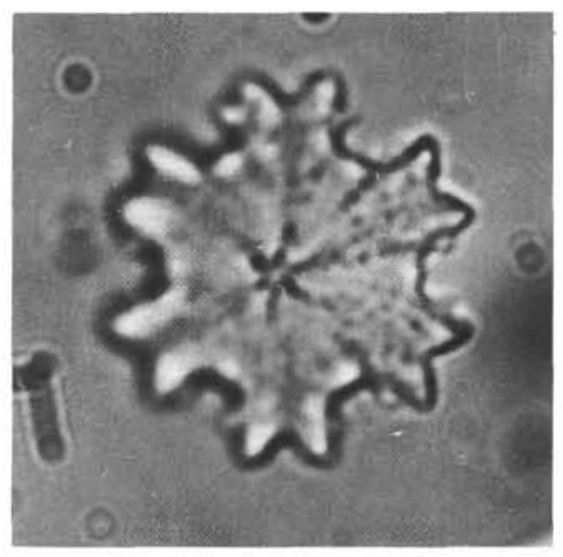

5

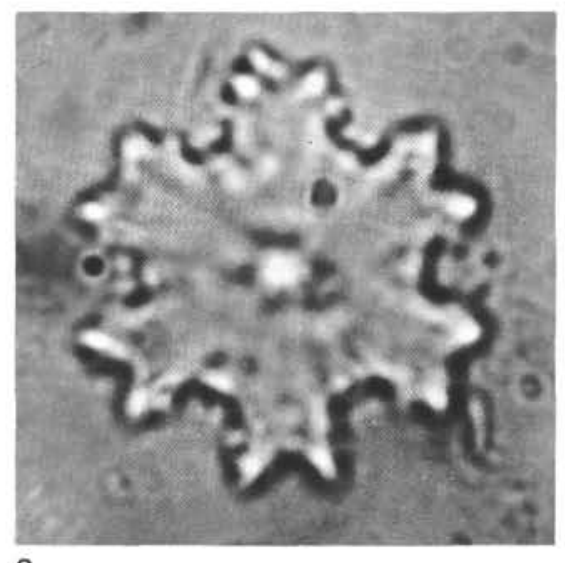

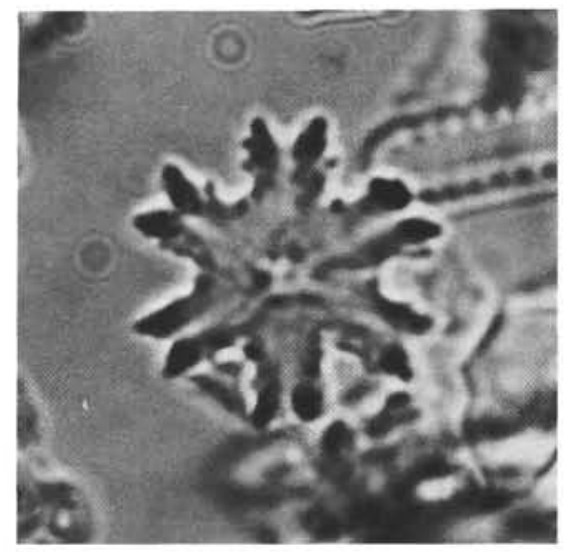

3
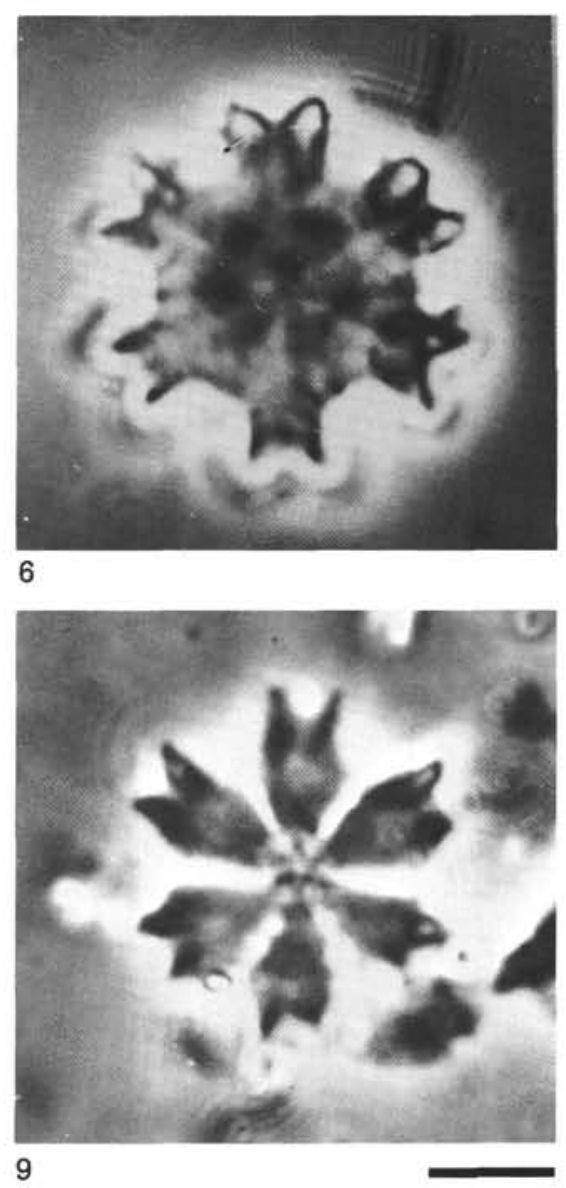

Plate 5 (scale bar $=5 \mu \mathrm{m}$; Figs. 1-6, Sample 493-33-4, 57-58 cm; Figs. 7-9, Sample 489-1,CC; Figs. 1, 3, 5, 8, NL; Figs. 2, 4, 6, 7, 9, PHC). 1-9. Discoaster calculosus Bukry. 


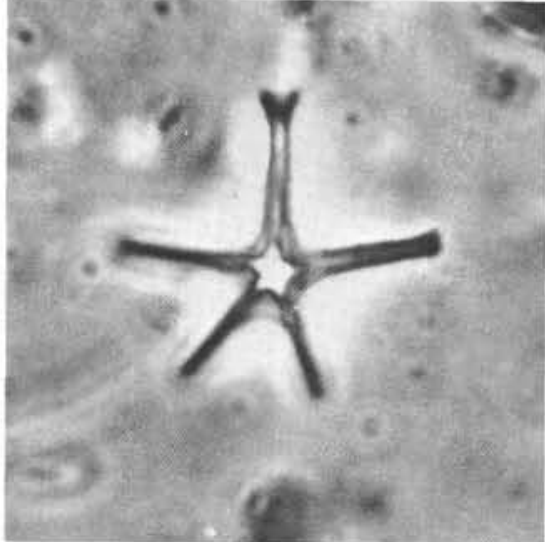

1

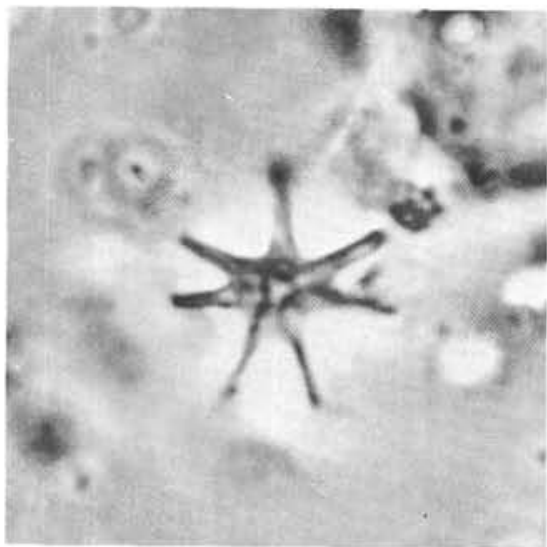

4

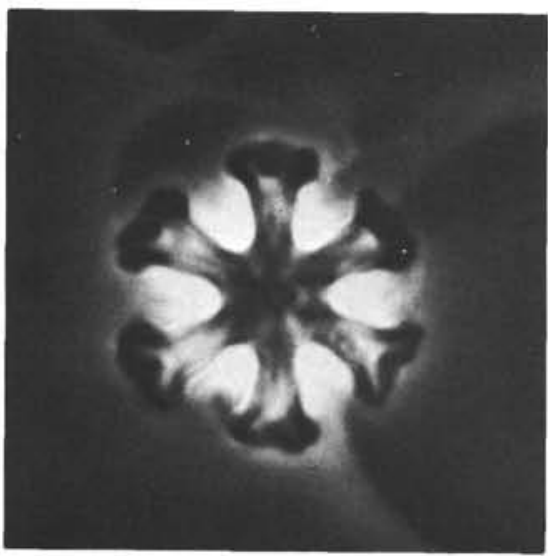

7

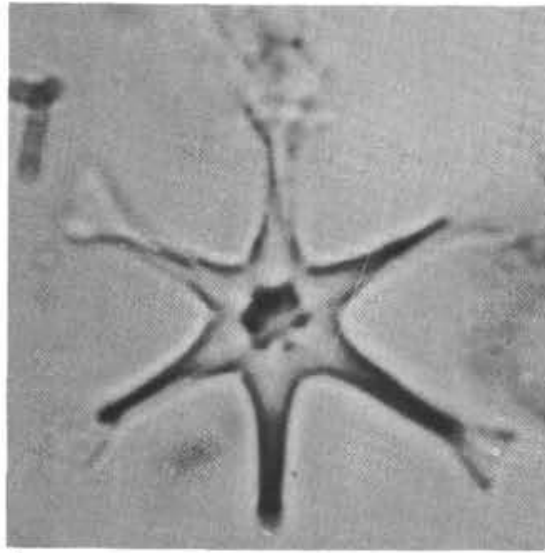

2

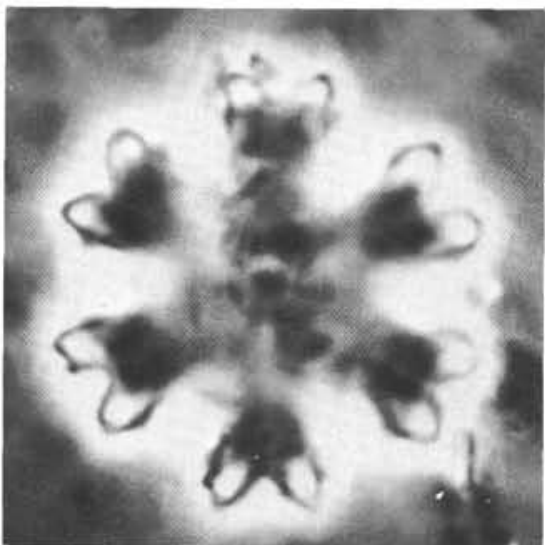

5

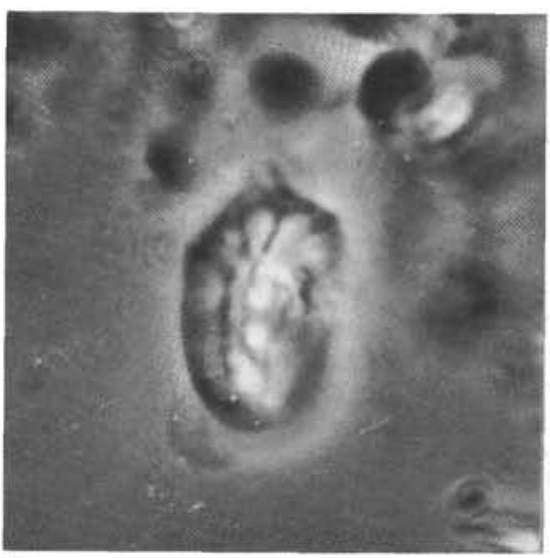

8

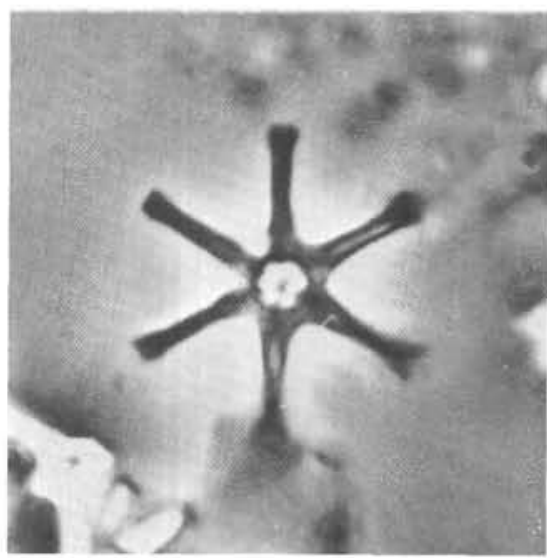

3
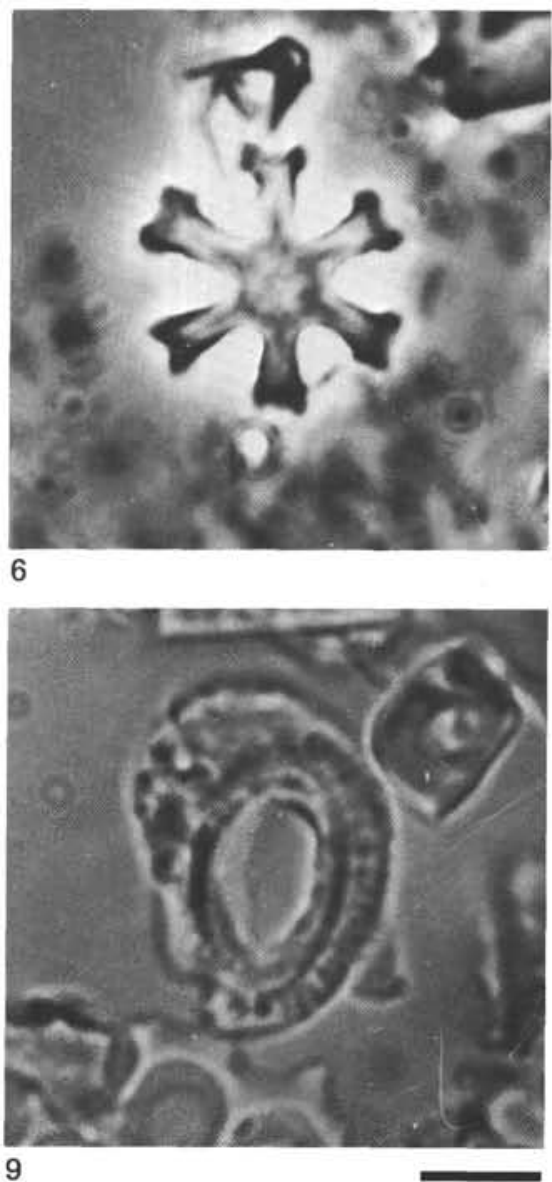

Plate 6. Photomicroscopic pictures of early Miocene discoasters and placoliths (scale bar $=5 \mu \mathrm{m}$. Figs. 1, 3, 4-8, Sample 489-1,CC; Figs. 2, 9, Sample 493-33-4, 57-58 cm). 1-4. Discoaster exilis Martini and Bramlette, NL, irregular specimens in Figures 1 and 4. 5. Discoaster calculosus Bukry, PHC. 6, 7. Discoaster aulakos Gartner, PHC. 8. Helicosphaera carteri (Wallich) Kamptner, NL. 9. Helicosphaera cf. ampliaperta Bramlette and Wilcoxon, NL. 


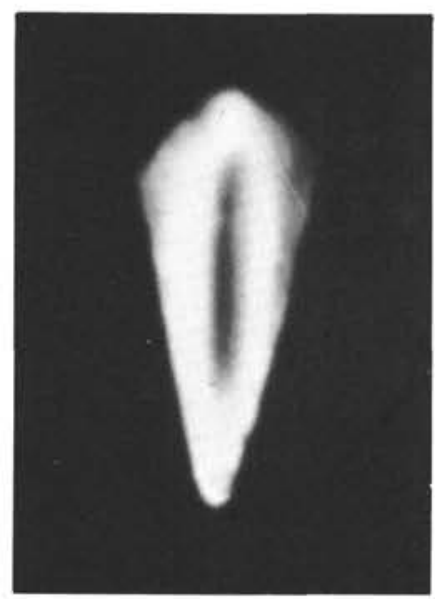

1

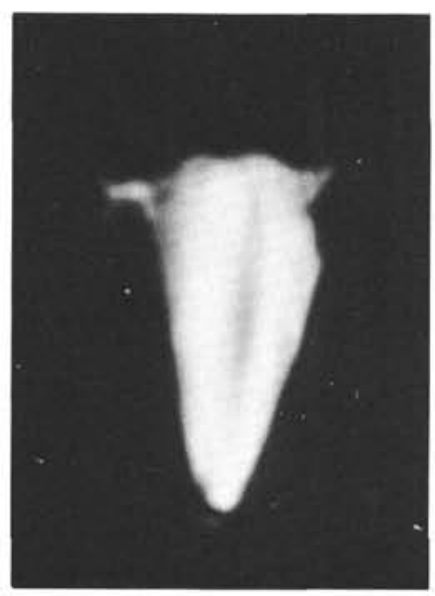

4

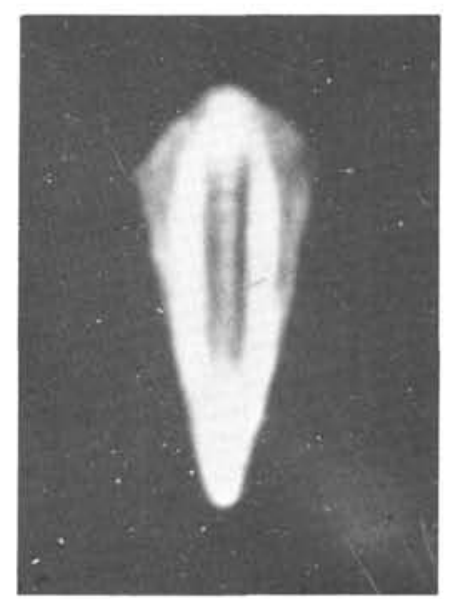

2

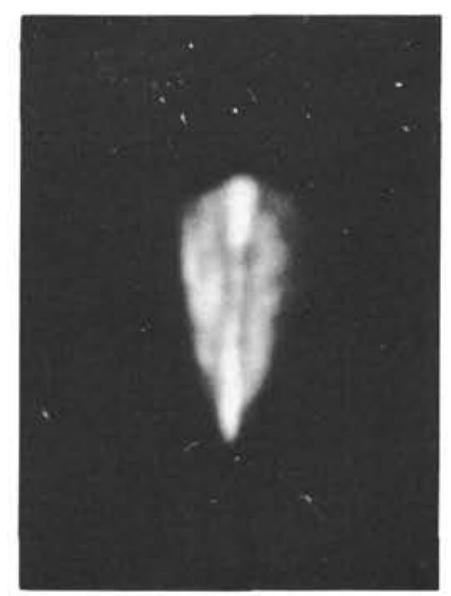

5

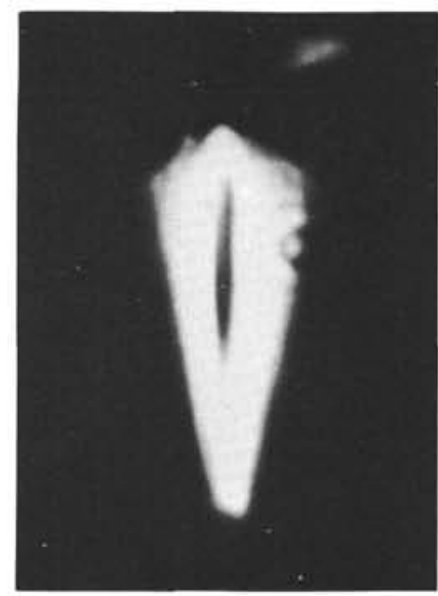

3

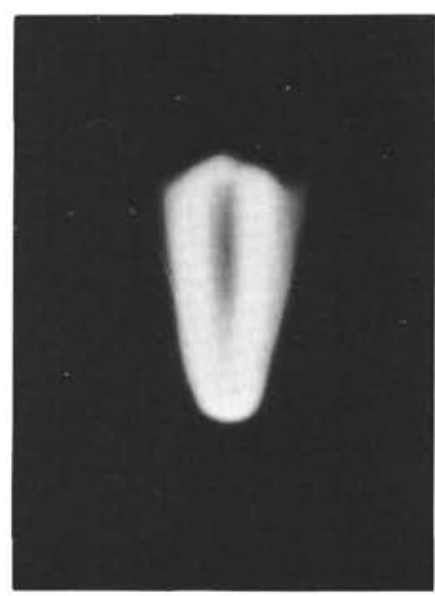

6

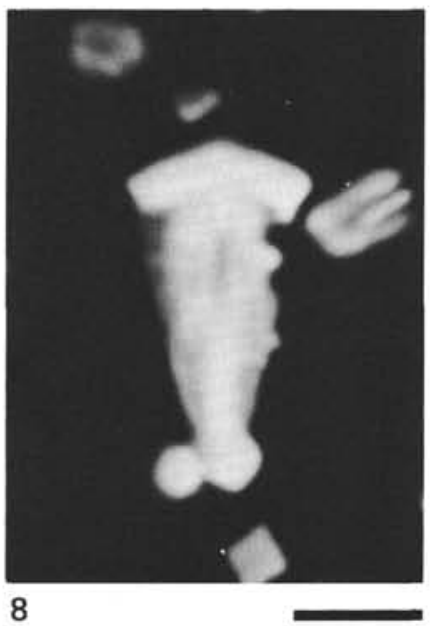

Plate 7. Photomicroscopic pictures of Triquetrorhabdulus auritus (nov. spec. holotype specimen: Figs. 1, 2; paratype specimens: Figs. 3-6; corroded specimens: Figs. 7, 8; all side views, XNIC; Figs. 1-4, 6-8, Sample 489A-12-CC; Fig. 5, Sample 493-53,CC; scale bar = $5 \mu$ m). 

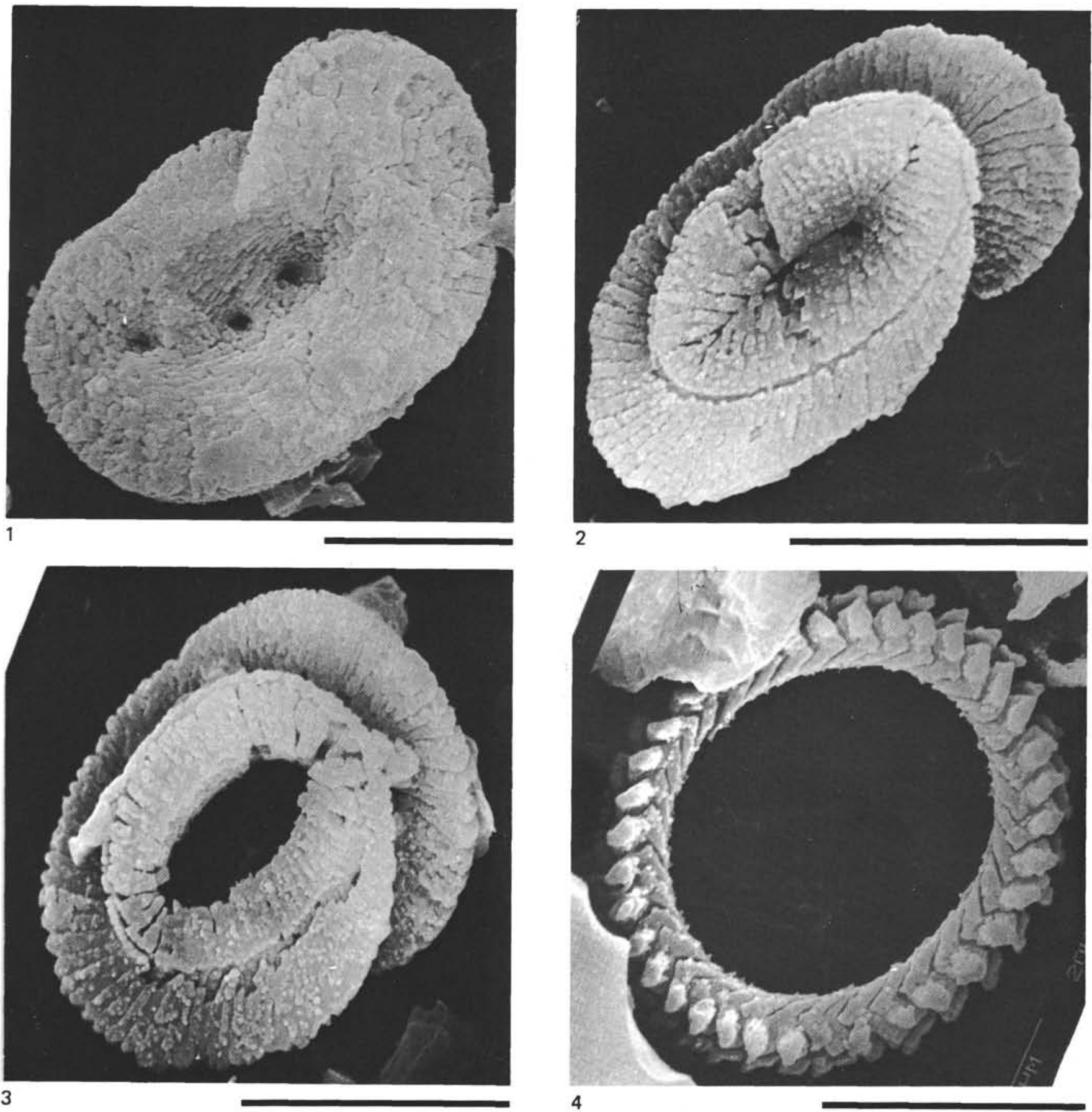

Plate 8 (scale bar $=5 \mu \mathrm{m}$; Sample 493-33-4, 57-58 cm). 1. Helicosphaera carteri (Wallich) Kamptner, distal view, SEM. 2. Helicosphaera carteri (Wallich) Kamptner, proximal view, SEM. 3. Helicosphaera $\mathrm{cf}$. ampliaperta Bramlette and Wilcoxon, proximal view, SEM. 4. Coronocyclus nitescens (Kamptner) Bramlette and Wilcoxon, plane view, SEM. 

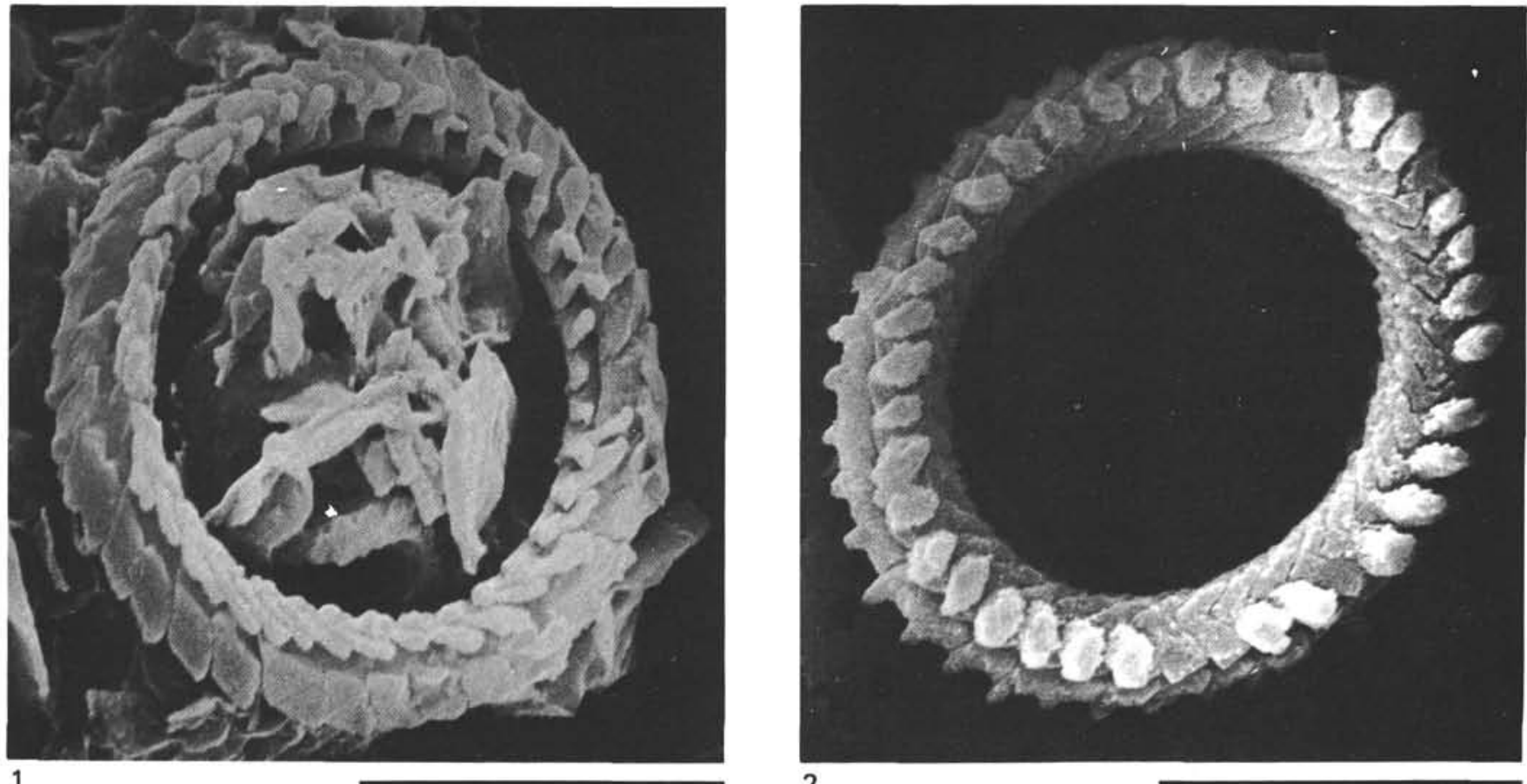

1
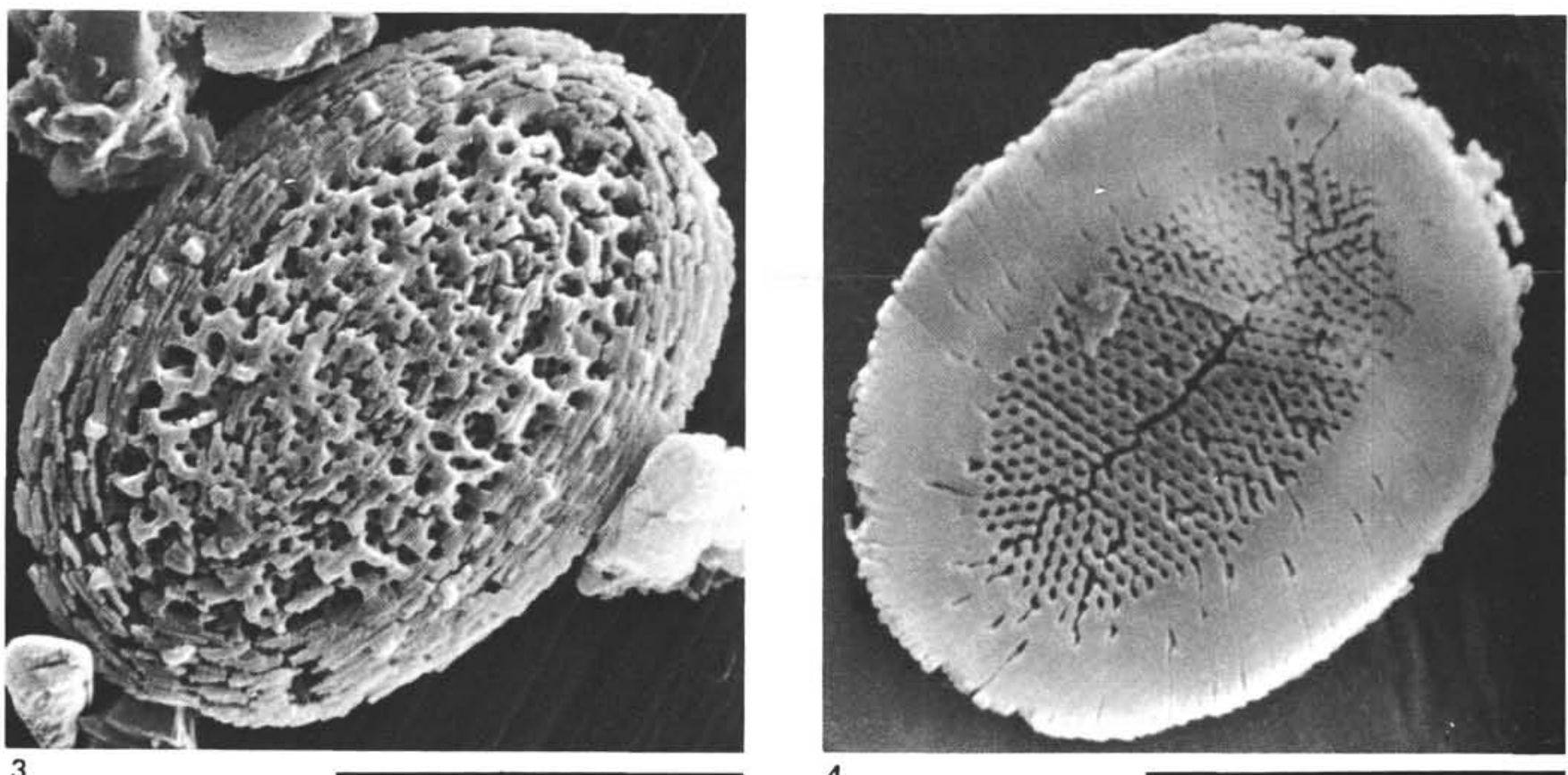

4

Plate 9 (scale bar $=5 \mu \mathrm{m}$; Figs. 1, 2, Sample 493-33-4, 57-58 cm; Figs. 3, 4, Sample 490-18-5, 27-28 cm). 1. Coronocyclus nitescens (Kamptner) Bramlette and Wilcoxon, plane view of one side, SEM. 2. Coronocyclus nitescens (Kamptner) Bramlette and Wilcoxon, plane view of other side, SEM. 3. Discolithina japonica Takayama, distal side, SEM. 4. Discolithina japonica Takayama, proximal side, SEM. 

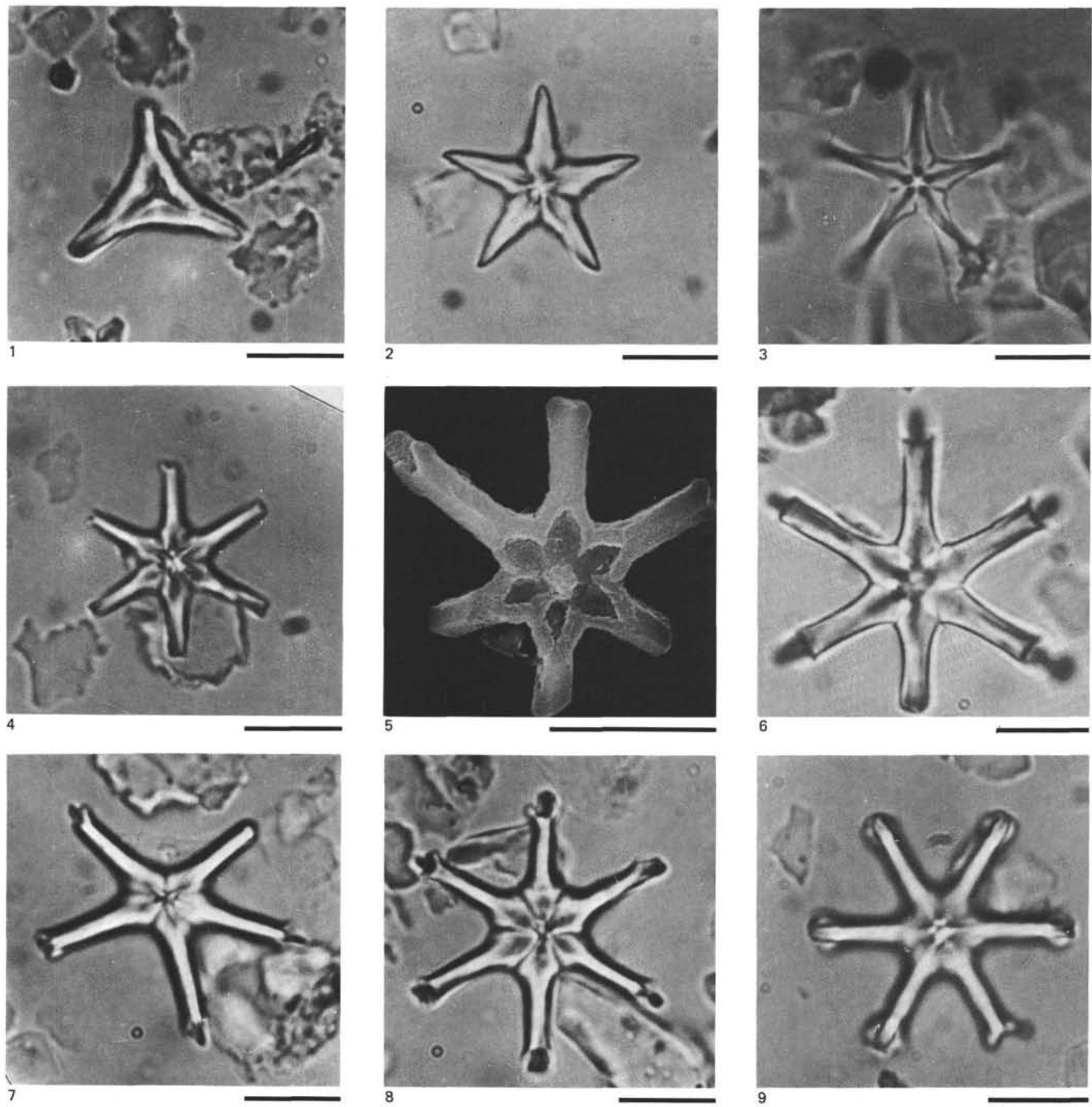

Plate 10. Discoasters from a late Pliocene nannoplankton assemblage (scale bar $=5 \mu \mathrm{m}$; Sample 493B-11-3, 60-61 cm; all figures NL except Fig. 5 , SEM). 1, 5, 7. Discoaster cf. surculus Martini and Bramlette. 2, 3. Discoaster $\mathrm{cf}$. pentaradiatus Tan, LM. 4-6, 8, 9. Discoaster pseudovariabilis Martini and Worsley. 


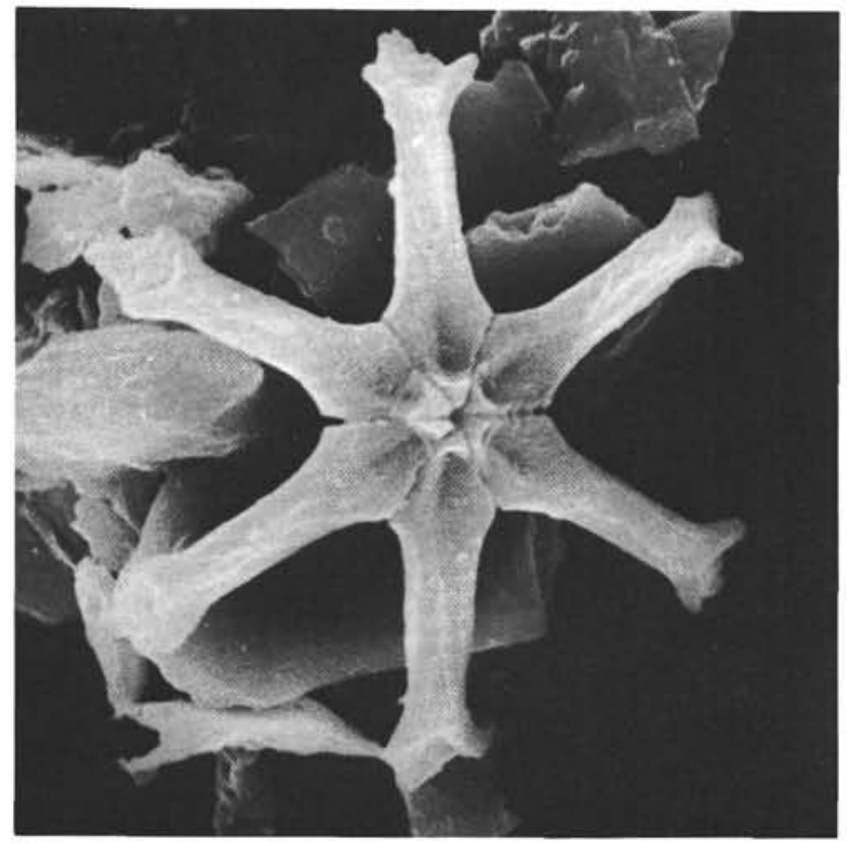

1

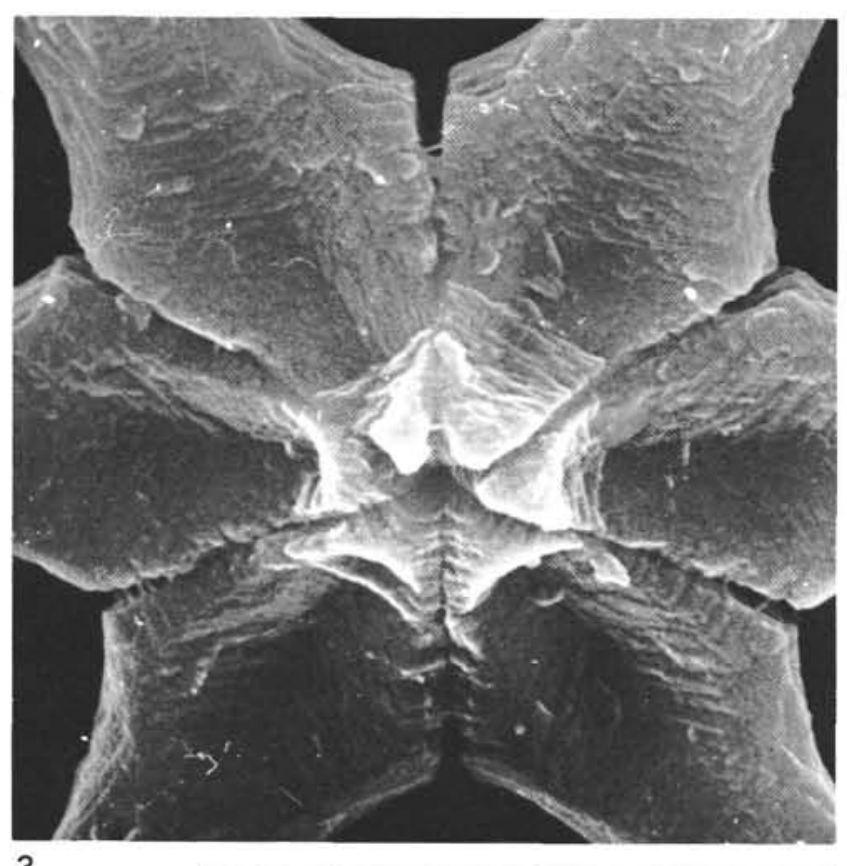

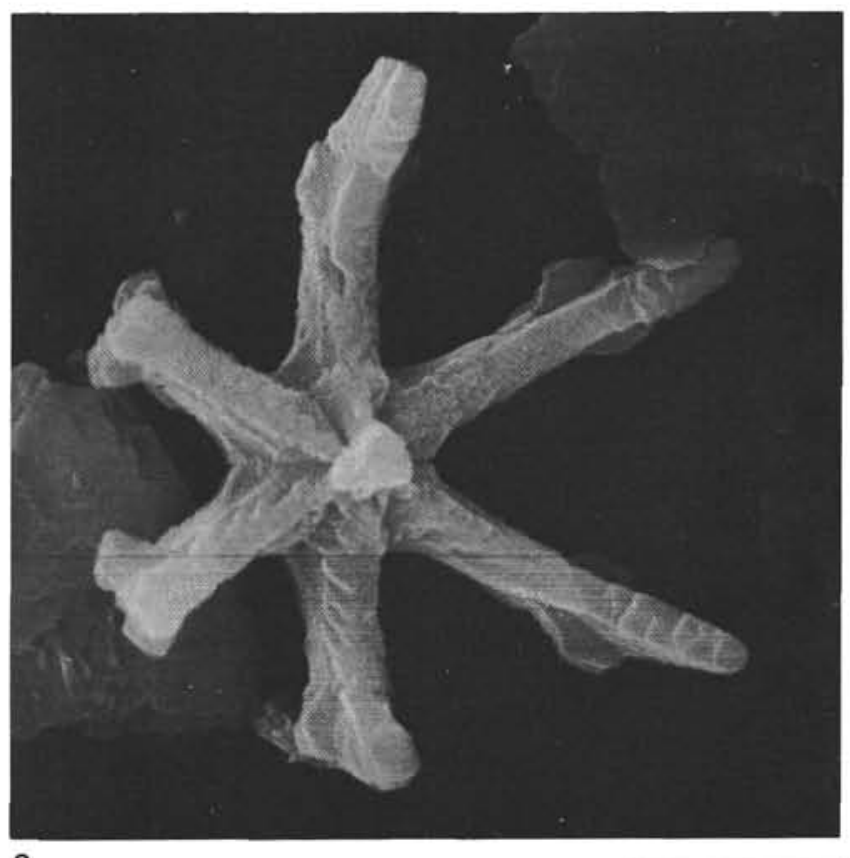

2

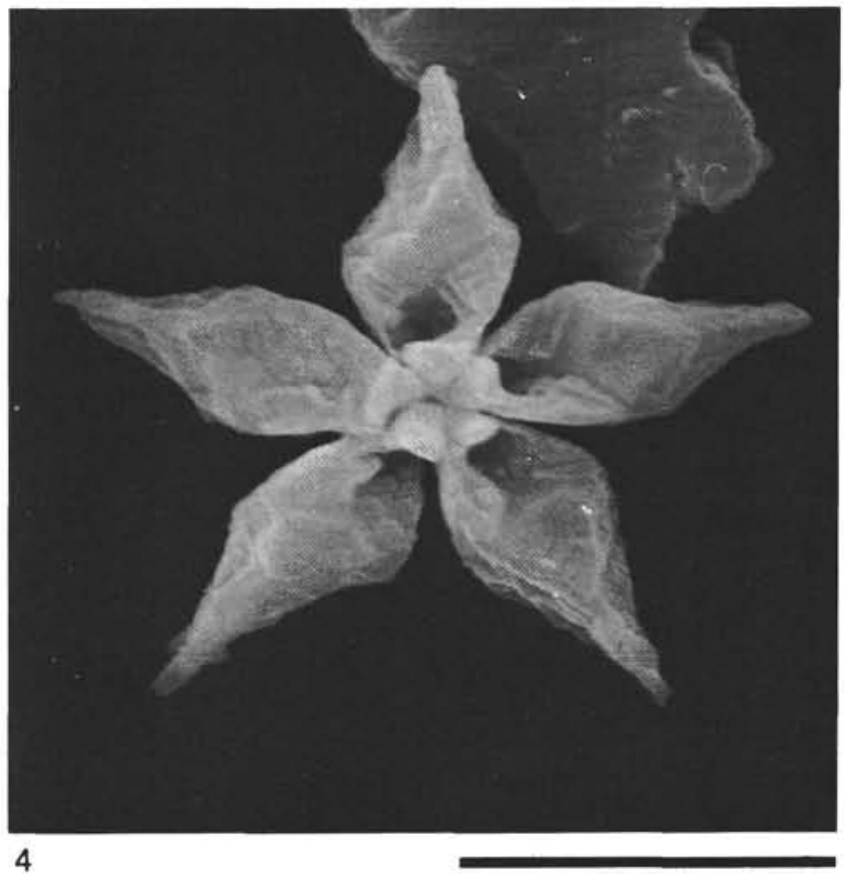

Plate 11 (scale bar $=5 \mu \mathrm{m}$; Figs. 1-3, Sample 493B-11-3, 60-61 cm; Fig. 4, Sample 493-18,CC). 1. Discoaster surculus Martini and Bramlette, distal side, SEM. 2. Discoaster surculus Martini and Bramlette, proximal side, SEM. 3. Detail of Figure 1, central area with slight etching. 4. Discoaster quinqueramus Gartner, etched specimen, SEM. 

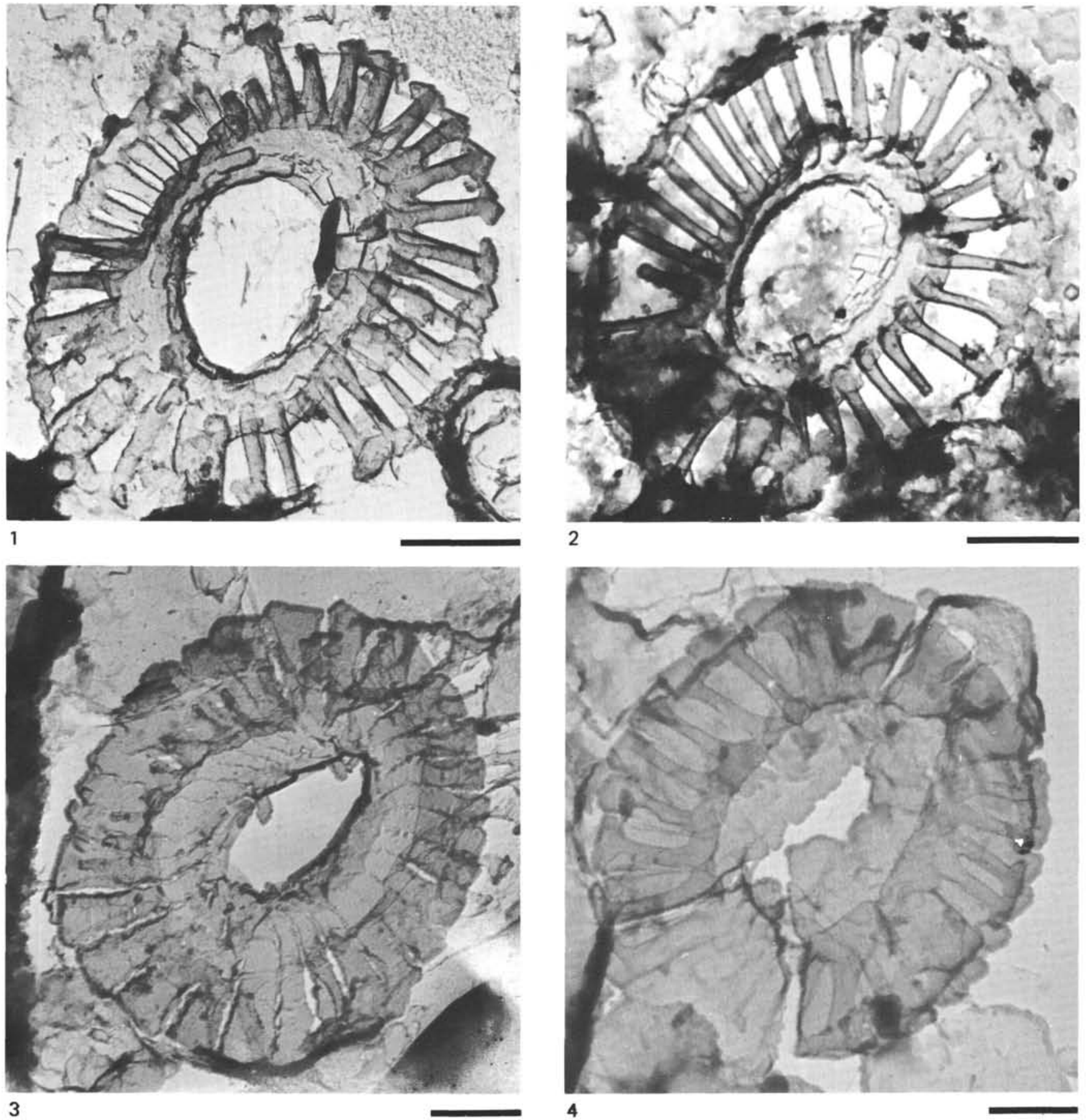

Plate 12 (scale bar $=5 \mu \mathrm{m}$; Sample 493A-2-3, 2-3 cm). 1. Emiliania huxleyi (Lohmann) Hay and Mohler, distal view, TEM. 2. Emiliania huxleyi (Lohmann) Hay and Mohler, distal shield, TEM. 3. Gephyrocapsa protohuxleyi Macintyre, distal side TEM. 4. Gephyrocapsa protohuxleyi MacIntyre proximal side, TEM. 

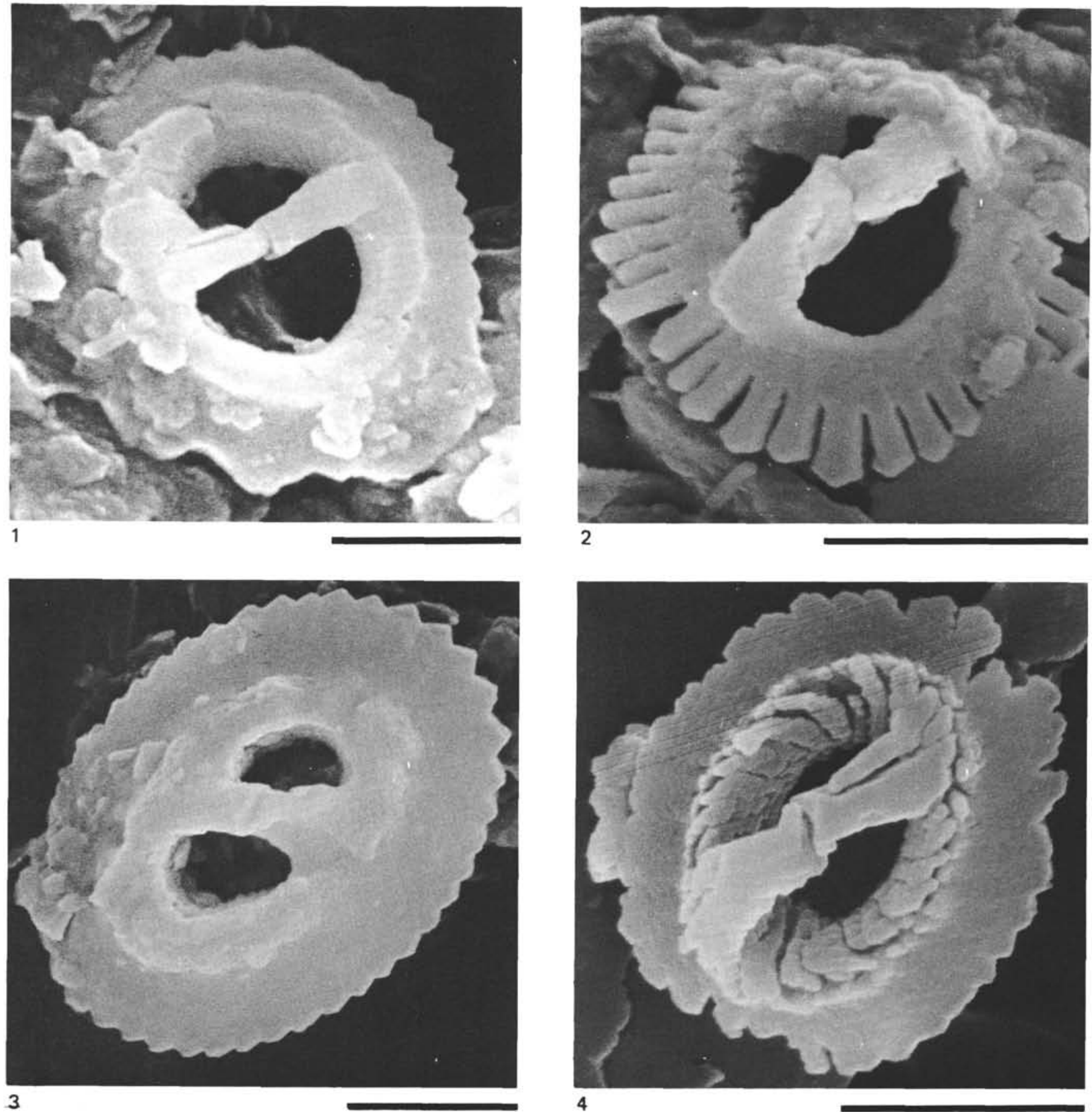

Plate 13 (scale bar $=2 \mu \mathrm{m}$; Fig. 1, Sample 493A-2-3, 2-3 cm; Figs. 2, 3, Sample 489-1,CC; Fig. 4, Sample 490-18-5, 27-28 cm). 1. Gephyrocapsa omega Bukry, distal side. 2. Gephyrocapsa oceanica Kamptner, distal side, partly corroded. 3. Gephyrocapsa caribbeanica Boudreaux and Hay, distal side. 4. Gephyrocapsa caribbeanica Boudreaux and Hay, distal side. 

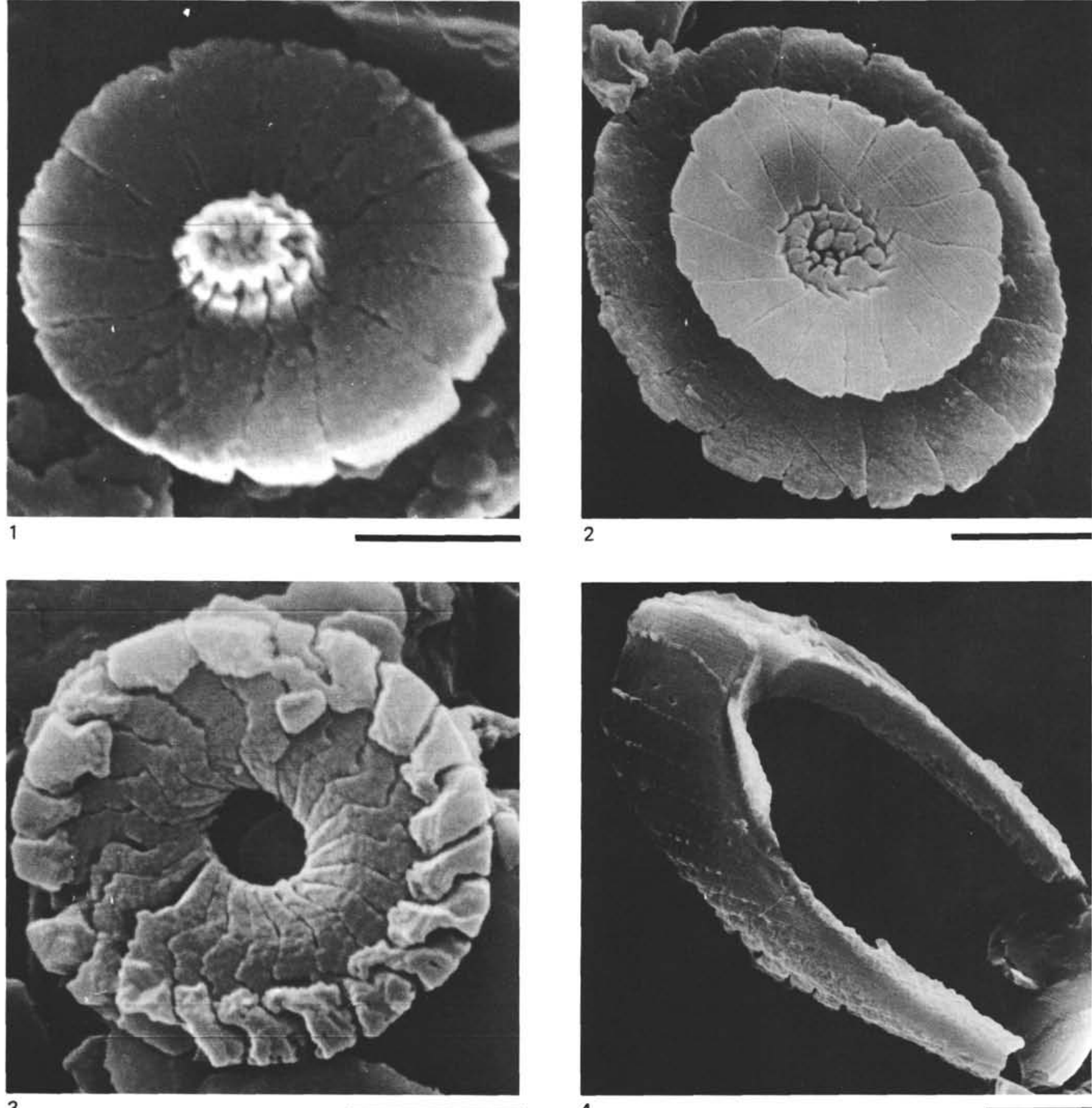

Plate 14 (scale bar $=2 \mu \mathrm{m}$; Fig. 1, Sample 490-1-4, 25-26 cm; Figs. 2-4, Sample 490-18-5, 27-28 cm). 1. Calcidiscus leptoporus (Murray and Blackman) Loeblich and Tappan, proximal view of separate distal shield, SEM. 2. Calcidiscus leptoporus (Murray and Blackman) Loeblich and Tappan, proximal view, SEM. 3. Calcidiscus sp, with heavy calcite overgrowth on distal shield, SEM. 4. Ceratolithus sp. cf. C. cristatus Kamptner, oblique view, SEM. 